INTER NATIONAL MONETARY FUND

Nicaragua: 2005 Article IV Consultation, Seventh, Eighth, and Ninth Reviews Under the Three Year Arrangement Under the Poverty Reduction and Growth Facility, Requests for Rephasing and Waiver of Performance Criteria, Financing Assurances Review, and Request for Extension of the Arrangement—Staff Report; Staff Statement; Public Information Notice and Press Release on the Executive Board Discussion; and Statement by the Executive Director for Nicaragua

Under Article IV of the IMF's Articles of Agreement, the IMF holds bilateral discussions with members, usually every year. In the context of a combined discussion of the 2005 Article IV consultation with Nicaragua, the seventh, eighth, and ninth reviews under the three year arrangement under the Poverty Reduction and Growth Facility, requests for rephasing and a waiver of performance criteria, financing assurances review, and request for an extension of the arrangement, the following documents have been released and are included in this package:

- $\quad$ the staff report for the combined 2005 Article IV Consultation, Seventh, Eighth, and Ninth Reviews Under the Three Year Arrangement Under the Poverty Reduction and Growth Facility, Requests for Rephasing and Waiver of Performance Criteria, Financing Assurances Review, and Request for Extension of the Arrangement, prepared by a staff team of the IMF, following discussions that ended on November 23, 2005, with the officials of Nicaragua on economic developments and policies. Based on information available at the time of these discussions, the staff report was completed on December 28, 2005. The views expressed in the staff report are those of the staff team and do not necessarily reflect the views of the Executive Board of the IMF.

- a staff statement of January 18, 2006 updating information on recent economic developments.

- a Public Information Notice (PIN) and Press Release, summarizing the views of the Executive Board as expressed during its January 18, 2006, discussion of the staff report on issues related to the Article IV consultation and the IMF arrangement, respectively.

- $\quad$ a statement by the Executive Director for Nicaragua.

The documents listed below have been or will be separately released.

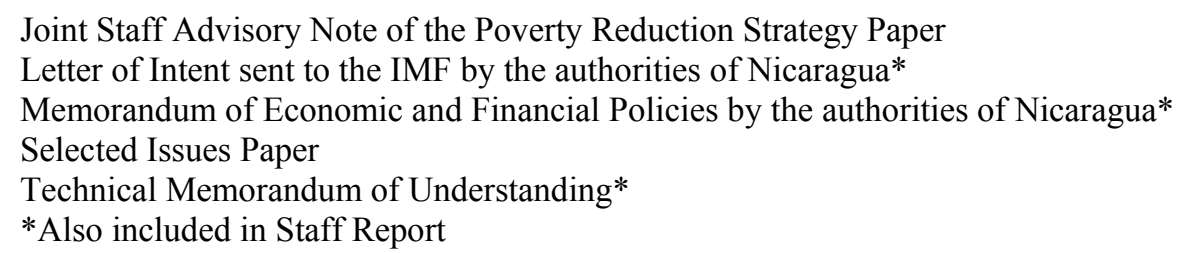

The policy of publication of staff reports and other documents allows for the deletion of market-sensitive information.

To assist the IMF in evaluating the publication policy, reader comments are invited and may be sent by e-mail to publicationpolicy@imf.org.

Copies of this report are available to the public from

International Monetary Fund • Publication Services

$70019^{\text {th }}$ Street, N.W. • Washington, D.C. 20431

Telephone: (202) 623-7430 • Telefax: (202) 623-7201

E-mail: publications@imf.org • Internet: http://www.imf.org

Price: $\$ 15.00$ a copy

International Monetary Fund

Washington, D.C. 
This page intentionally left blank

CInternational Monetary Fund. Not for Redistribution 
NICARAGUA

\title{
Staff Report for the 2005 Article IV Consultation, Seventh, Eighth, and Ninth Reviews Under the Three Year Arrangement Under the Poverty Reduction and Growth Facility, Requests for Rephasing and Waiver of Performance Criteria, Financing Assurances Review, and Request for Extension of the Arrangement
}

\author{
Prepared by Western Hemisphere Department
}

(In consultation with other departments)

Approved by Charles Collyns (WHD) and Adnan Mazarei (PDR)

December 28, 2005

- $\quad$ Arrangement. A three-year PRGF arrangement was approved on December 13, 2002, for an amount equivalent to SDR 97.5 million (75 percent of the quota) and was set to expire in December 2005. On September 8, 2004, the Executive Board concluded the fifth and sixth reviews with an associated disbursement of SDR 13.93 million. However, the PRGF arrangement went off track in the latter part of 2004 reflecting passage of a 2005 budget with large increases in public sector wages and stalled structural reforms. The authorities have since taken significant measures to strengthen the macroeconomic framework and reinvigorate the structural reform program. In December 2005, the PRGF arrangement was extended through end-February 2006 to allow time for completion of prior actions before the current request for completion of reviews and extension of the arrangement.

- $\quad$ Article IV. The last Article IV consultation was concluded on December 4, 2002. At the time of the previous consultation, directors expressed concern over the deterioration in Nicaragua's economic performance, but welcomed the new governments commitment to correct the economy's key vulnerabilities, including strengthening the financial sector and governance. They stressed the importance of sustained fiscal consolidation and welcomed the focus of the monetary strategy on building international reserves while maintaining low inflation. The delay in the consultation cycle reflects the authorities' desire to bring the PRGF arrangement back on track in the context of completing the consultation.

- Mission. The mission visited Managua during September 7-22, 2005, comprising Vikram Haksar (head), Sergio Martin, Jordi Prat, Rita Babihuga (all WHD), Jean-François Dauphin (PDR), and Alejandro Simone (FAD); and was assisted by Humberto Arbulú-Neira (resident representative). The mission met with President Bolaños, Finance Minister Arana, Central Bank President Alonso, and other senior officials, representatives of the National Assembly, civil society, and the private sector. A follow-up mission to conclude the program discussions took place during November 15-22, 2005 and spoke before the "National Dialogue" comprising key leaders of all political parties in Nicaragua.

- Selected Issues Papers. The accompanying staff papers look at: (i) the implications of CAFTA-DR, (ii) public sector wages, and (iii) the monetary framework.

Article VIII Obligations. Nicaragua has accepted the obligations of Article VIII, Sections 2, 3, and 4 of the Fund's Articles of Agreement and maintains an exchange system that is free of restrictions on the making of payments and transfers for current international transactions. 








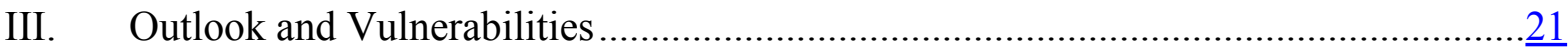





B. Monetary and Exchange Rate Policies ……………........................................





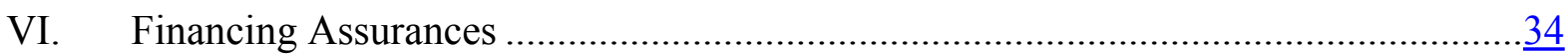





Boxes

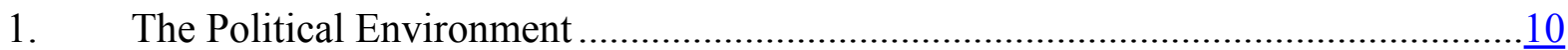

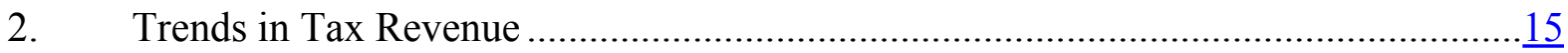



4. Financial System Vulnerability ......................................................................

5. Impact of Higher Oil Prices on the Nicaraguan Economy ………………………....

6. Competitiveness and Business Environment ...........................................................22

Figures

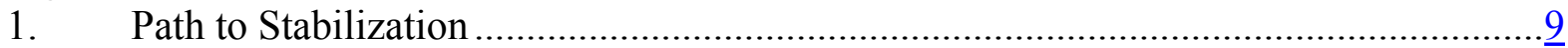

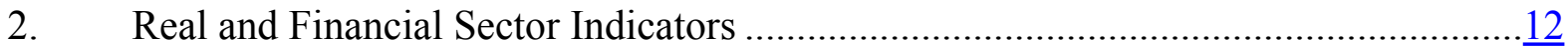

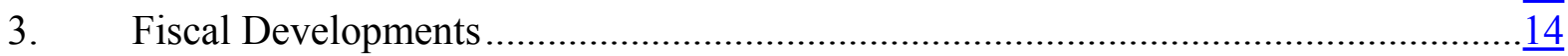



5. Alternative Medium-Term Macroeconomic Outlook ……………………………..... 
Tables

1. Selected Economic Indicators ......................................................................

2. Operations of the Central Government ............................................................. $\underline{40}$

3. Operations of the Combined Public Sector...................................................

4. Operations of the Central Government ............................................................... $\frac{42}{43}$

5. Operations of the Combined Public Sector..........................................................

6. Summary Accounts of the Central Bank ............................................................44

7. Summary Accounts of the Central Bank-Quarterly .......................................... 45

8. Summary Accounts of the Deposit Banks and the Financial Sector ......................... $\underline{46}$



10. Balance of Payments .............................................................................. $\underline{48}$



12. Indicators of Fund Credit ....................................................................... $\frac{50}{51}$

13. Medium-Term Macroeconomic Framework (Baseline) ...................................... $\frac{51}{52}$

14. Medium-Term Macroeconomic Framework (Alternative) .................................... $\frac{52}{53}$

15. Millennium Development Goals.......................................................................53

Appendices



II. Relations with the World Bank Group................................................................ $\frac{58}{59}$

III. Relations with the Inter-American Development Bank ........................................ $\underline{59}$



V. Debt Sustainability Analysis..............................................................64

Attachments

I. Letter of Intent ..................................................................................... 76

II. Supplementary Memorandum of Economic and Financial Policies.......................... $\underline{78}$

Table 1. Prior Actions, Structural Performance Criteria, and Benchmarks for

Completion of Reviews................................................................................ $\frac{86}{88}$

Table 2. Quantitative Performance Criteria (2004) .............................................. $\frac{88}{89}$

Table 3. Quantitative Performance Criteria (2006) ................................................. $\frac{89}{90}$

III. Technical Memorandum of Understanding ................................................... $\underline{90}$ 


\section{Abbreviations and Acronyms}

\begin{tabular}{|c|c|}
\hline $\mathrm{BCN}$ & Central Bank of Nicaragua \\
\hline $\mathrm{BCP}$ & Basel Core Principles \\
\hline BPI & Indemnity Bonds \\
\hline BPMS & Balance of Payments Manual \\
\hline CAFTA-DR & Central America-Dominican Republic-United States Free Trade Agreement \\
\hline $\mathrm{CG}$ & Central Government \\
\hline CPI & Consumer Price Index \\
\hline CPIA & Country Policy and Institutional Assessment Index \\
\hline CPS & Combined Public Sector \\
\hline DGA & General Directorate of Customs \\
\hline DGI & General Directorate of Internal Revenue \\
\hline DRF & World Bank's Debt Reduction Facility \\
\hline DSA & Debt Sustainability Analysis \\
\hline ENACAL & Nicaraguan Water and Sewerage Company \\
\hline ENEL & Nicaraguan Electricity Company \\
\hline ESL & Energy Stability Law \\
\hline FAD & Fiscal Affairs Department \\
\hline FAL & Financial Administration Law \\
\hline FISE & Emergency Social Investment Fund \\
\hline FOGADE & Deposit Guarantee Fund \\
\hline FRL & Fiscal Responsibility Law \\
\hline FSAP & Financial Sector Assessment Program \\
\hline GDDS & General Data Dissemination System \\
\hline GFS & Government Financial Statistics \\
\hline GFSM2001 & GFS Manual 2001 \\
\hline GFSY & Government Financial Statistics Yearbook \\
\hline HIPC & Heavily Indebted Poor Countries \\
\hline IAS & International Accounting Standards \\
\hline IDB & Inter-American Development Bank \\
\hline IFS & International Financial Statistics \\
\hline INIFOM & Nicaraguan Institute of Municipal Development \\
\hline ISN & Interim Strategy Note \\
\hline LEG & Legal Department \\
\hline LOI & Letter of Intent \\
\hline LTU & Large Taxpayers Unit \\
\hline MDG & Millennium Development Goals \\
\hline MDRI & Multilateral Debt Relief Initiative \\
\hline MEFP & Memorandum of Economic and Financial Policies \\
\hline MFD & Monetary and Financial Affairs Department \\
\hline MoF & Ministry of Finance \\
\hline NDP & National Development Plan \\
\hline NFPS & Nonfinancial Public Sector \\
\hline NIR & Net International Reserves \\
\hline
\end{tabular}




$\begin{array}{ll}\text { NPL } & \text { Nonperforming Loans } \\ \text { NPV } & \text { Net Present Value } \\ \text { PC } & \text { Performance Criterion } \\ \text { PLC } & \text { Partido Liberal Constitucionalista } \\ \text { PRGF } & \text { Poverty Reduction and Growth Facility } \\ \text { PRSC } & \text { Poverty Reduction Support Credit } \\ \text { PRSP } & \text { Poverty Reduction Strategy Paper } \\ \text { PSIA } & \text { Poverty and Social Impact Analysis } \\ \text { REER } & \text { Real Exchange Rate } \\ \text { SB } & \text { Superintendency of Banks } \\ \text { SECEP } & \text { Secretariat of Coordination and Strategy of the Presidency } \\ \text { SFO } & \text { Special Fund Operations } \\ \text { SIGFA } & \text { Integrated System for Financial Management and Auditing } \\ \text { SMEFP } & \text { Supplementary Memorandum of Economic and Financial Policies } \\ \text { TA } & \text { Technical Assistance } \\ \text { TMU } & \text { Technical Memorandum of Understanding } \\ \text { TPC } & \text { Tax Procedures Code } \\ \text { VAT } & \text { Value-added Tax } \\ \text { WB } & \text { World Bank } \\ \text { y/y } & \text { year on year }\end{array}$




\section{EXECUTIVE SUMMARY}

\section{Background}

The authorities have sought to rebuild the domestic consensus for economic reforms in the face of a difficult political environment. From late 2004, political tensions associated with disputes between the legislative and executive branches arrested the reform agenda and drove the program off track. In recent months, however, a political accord has fostered a flurry of legislative activity on prior actions for the program as well as early passage of the 2006 budget.

The economy continued to perform well, notwithstanding pressure from higher oil prices. Strong performance under the program in 2003-04 allowed Nicaragua to reach the HIPC completion point in January 2004. Since then, growth has moderated towards 4.1 percent $\mathrm{y} / \mathrm{y}$ in 2005 and inflation has picked up to over 10 percent $\mathrm{y} / \mathrm{y}$, as rising international oil prices have been passed through to domestic fuel prices. High oil prices have driven large losses in the power sector, although recently, electricity tariffs have been adjusted. Strong export growth has allowed a modest rise in reserves, despite a higher oil import bill. The 2005 budget included large public sector wage increases, an important factor delaying completion of pending program reviews, but a tax package and spending controls have helped to slightly reduce the consolidated public sector deficit to 2.2 percent of GDP.

Key medium-term challenges include addressing vulnerabilities arising from weak balance sheets, reflected in high levels of debt and dollarization. It will also be crucial to strengthen further the fiscal framework to safeguard poverty-reducing spending and improve the business environment to leverage the potential of CAFTA-DR to support growth and achievement of the MDGs.

\section{Policy issues}

Crucial structural reforms have been passed as prior actions for the program. These include steps to strengthen the fiscal framework, including on decentralization and budget control, as well as passage of three important financial sector laws embodying several FSAP recommendations. The program for 2006 includes key additional structural commitments, most importantly modifications to the recently approved tax code, which otherwise risks weakening tax administration. The authorities also intend to develop strategies for advancing plans for pension reform and fiscal responsibility legislation, for implementation after the elections.

The 2006 budget remains tight in an election year. The CPS deficit is expected to remain unchanged at 2.2 percent of GDP despite one-time election-related costs of about 1 percent of GDP. Growth in the public sector wage bill has been contained broadly in line with expected inflation. Electricity tariffs will continue to be adjusted to eliminate quasi-fiscal losses in the sector. 
Monetary policy will continue to be guided by the crawling peg exchange regime. The central bank intends to take steps to slow down the growth of liquidity and credit to safeguard reserves, contain demand pressures on inflation, and maintain stability in the runup to next year's elections, which remain a key source of near-term uncertainty. 


\section{INTRODUCTION AND HISTORICAL CONTEXT}

1. The 2005 Article IV Consultation provides an important opportunity to take stock of achievements under the authorities' reform program and the challenges ahead. Over the last years, the economy has grown in the context of a stable macro-framework. Poverty reducing spending has increased and human development indicators have improved. Nonetheless, Nicaragua remains the second-poorest country in Latin America. Half of the population lives below the poverty line, with 15 percent living in extreme poverty. Still high debt levels, large current account deficits and high levels of dollarization will require careful macro management and concessional donor support over the medium term. The key focus should be on policies that boost growth and poverty reduction, especially those that encourage private investment, strengthen the fiscal framework, and protect the health of the financial sector.

\section{Nicaragua experienced an economic collapse during the 1980s with recovery} over the 1990s. By the late 1980s, real per capita income had fallen to one-third of its level of a decade earlier and the country had experienced hyperinflation. With the return of democracy in 1990, and significant donor support in the context of successive Fund programs, the economy began to recover (Figure 1). The economy has also increasingly benefited from rising flows of workers' remittances and FDI. The recovery has been associated, however, with an economic structure highly dependent on foreign grants, helping to finance large twin deficits. The latter part of the 1990s was marred by corruption, weak fiscal policy, and an accommodative monetary policy. These problems culminated in a banking crisis in 2000, which resulted in a jump in public debt of 20 percentage points of GDP and a major loss of international reserves.

3. In early 2002, the new Bolaños government implemented strong reforms. The administration put in place a tax reform, streamlined expenditures, and strengthened enforcement of prudential rules for banks. The government also took firm measures to improve governance, including imprisoning former President Alemán (head of the Liberal Party) on corruption charges. The authorities' program was supported through a three-year PRGF arrangement approved in December 2002. The program began to pay quick dividends - in 2003 GDP growth recovered, inflation remained subdued, and NIR increased, facilitating macro stability and some progress on structural reform.

\section{However, political tensions rose sharply from early 2004 contributing to an} environment that drove the program off track (Box 1). The escalation of latent tensions between the executive and legislative branches of government stalled the structural reform effort. The situation was compounded following approval of a 2005 budget that widened the deficit relative to the executive's proposal and included significant public sector wage increases. Together, these developments delayed, for over a year, the completion of pending program reviews under the PRGF arrangement after September 2004.

5. A recent political accord between President Bolaños and the opposition political parties has allowed re-starting the reform agenda, although risks remain. The key 
Figure 1. A Path to Stabilization

Income per capita fell sharply in the 1980s and has recovered slowly...

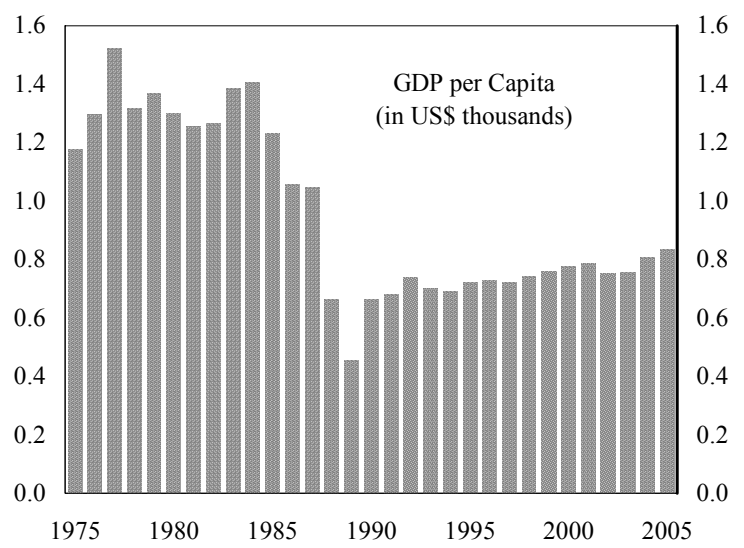

... and the economy has grown...



... and large current account deficits financed by foreign transfers...



... after a period of hyperinflation, inflation has stabilized...



... though fiscal deficits have been high...



...while debt relief has resulted in a substantial reduction in the level of debt.



Source: Central Bank of Nicaragua. 


\section{Box 1. The Political Environment}

The political situation deteriorated significantly in late 2004. This reflected a political "pact" in late 2004 between the two main parties (Liberal and Sandinista) to approve a set of constitutional amendments aimed at curbing the power of the executive branch. President Bolaños rejected these amendments, setting the stage for a constitutional crisis that put the President under threat of being impeached and tested Nicaragua's institutional stability. Moreover, the structural agenda stalled as brokering a political truce proved to be elusive despite several rounds of negotiation.

In October 2005, however, Sandinista leader Ortega and President Bolaños reached a political accord to postpone pursuit of the constitutional amendments until after the upcoming general elections in November 2006. This accord, which has also drawn support from the Liberal party, in part reflects pressures from the international community to advance reforms as well as a political consensus to revive the program, including in the run-up to the MDRI. The political accord has made possible the approval of a large number of economic reform laws that were pending as prior actions for completing reviews and extending the PRGF arrangement.

The political outlook for the next year, however, remains fragile with the source of instability shifting to the national elections. Since the return of democracy in 1990, these elections have been contested mainly by the Sandinistas and the Liberals. President Bolaños cannot run for re-election. At the current moment, Sandinista leader Ortega has again declared his candidacy and the Liberal party is to hold a primary selection early next year. However, two alternatives have emerged from within the two main parties, responding to a high level of popular disenchantment

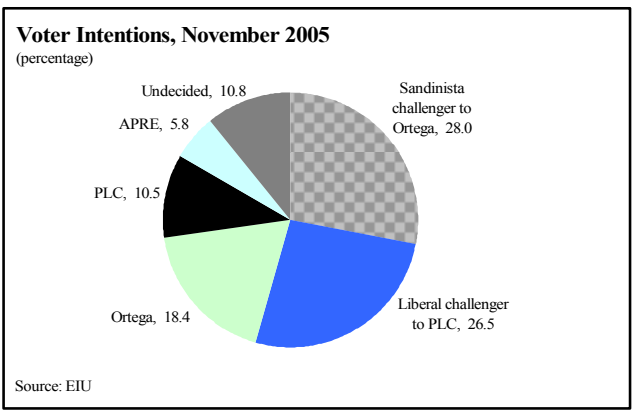
with their political "pact." Indeed, recent surveys indicate that these breakaway candidates have large leads in public opinion. However, it is unclear whether they will be able to build up a sufficiently strong party organization to effectively contest the elections. As such, the outlook for the elections remains very fluid at this stage.

political actors have agreed to defer controversial constitutional reforms - linked to the sharp political tensions that derailed the program - until after the November 2006 presidential and congressional elections. In a major step connected with this accord, the assembly approved CAFTA-DR, which had previously been blocked by the opposition Sandinista party. Since then, there has been a flurry of legislative activity on prior actions to put the program back on track. Nonetheless, political uncertainty remains high, especially as the country enters the run-up to the 2006 elections. This is a key factor driving the authorities' desire to extend the Fund-supported program to help provide an anchor for economic policies in the year ahead.

6. In the context of completion of prior actions and strengthened macro-policies, the authorities are requesting the completion of pending reviews and the extension of the PRGF arrangement. In the attached letter to the Managing Director (Attachment I), dated December 27, 2005, the authorities request: (i) waivers for the nonobservance of the 
quantitative performance criterion (PC) on the overall balance after grants of the central government at end-December 2004 and the structural performance criterion of submitting to the National Assembly a fiscal responsibility law (FRL) by October 15, 2004; (ii) the eighth, ninth and tenth disbursements under the arrangement, in the proposed rephased amount of SDR 13.93 million; and (iii) the extension of the arrangement until December 12, 2006. The authorities' memorandum of economic and financial policies (MEFP) and a revised technical memorandum of understanding (TMU) are also attached.

\section{RECENT ECONOMIC DEVELOPMENTS}

7. Macro developments in $\mathbf{2 0 0 4}$ were generally favorable while performance under the program was broadly satisfactory. Real GDP growth accelerated to 5.1 percent in 2004 on the back of a strong recovery in exports, higher commodity prices, and booming remittances. Private sector credit expanded rapidly. Nicaragua reached the HIPC completion point in January 2004, leading to delivery of external debt relief to date of about US $\$ 4 \frac{1}{2}$ billion in NPV terms. ${ }^{1}$ The combined public sector (CPS) deficit in 2004 was 2.8 percent of GDP compared with the program target of 4 percent of GDP. Strong external receipts, coupled with higher official financing, boosted NIR at end-2004 to US\$128 million over target. However, rising oil prices drove up end-2004 inflation to 9.3 percent. All but one quantitative PCs were met in 2004. ${ }^{2}$ The authorities missed the structural PC on submitting an FRL to the National Assembly by mid-October, as they were not able to form a domestic consensus on this important reform in a period of mounting political tensions.

\section{Economic growth is projected to have} moderated to 4 percent in 2005 (Figure 2).

Reflecting the impact of higher oil prices and weakening global demand, activity has slowed across most sectors, though agriculture output has so far held up. Export growth has also dropped off, in part because of lower agro-exports, while public investment has moderated reflecting delays in

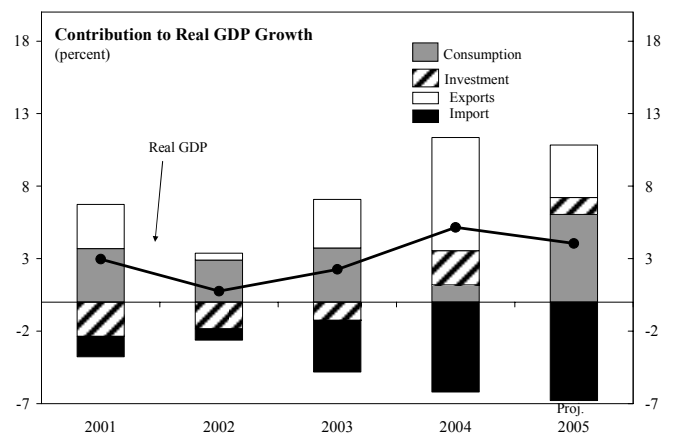

${ }^{1}$ At end-2004, the NPV of total recognized public debt was 120 percent of GDP. Assuming full delivery of HIPC relief, including from non-Paris Club and commercial creditors, the NPV of public debt would fall to about 70 percent of GDP. The implementation of the MDRI would reduce it further to about 60 percent of GDP.

${ }^{2}$ The authorities met all quantitative performance criteria (PCs) at end-June and endSeptember 2004. However, they missed the PC on the central government overall balance after grants at end-December 2004 by a narrow margin, owing to higher-than-programmed capital expenditure. All other PCs at end-December, including that on net international reserves, were met by comfortable margins. No targets were set for 2005 . 
Figure 2. Real and Financial Sector Indicators

Growth has moderated in 2005...

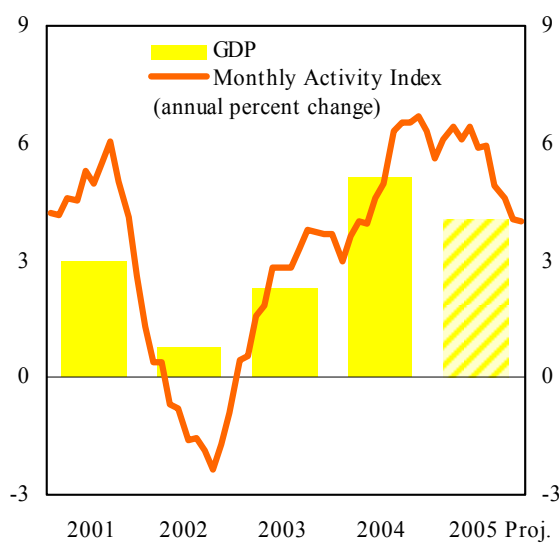

Bank credit has been growing strongly.

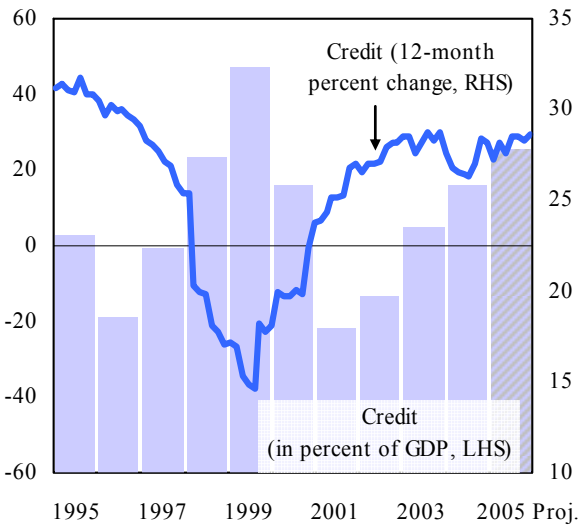

Inflation has been rising, partly due to higher oil prices.

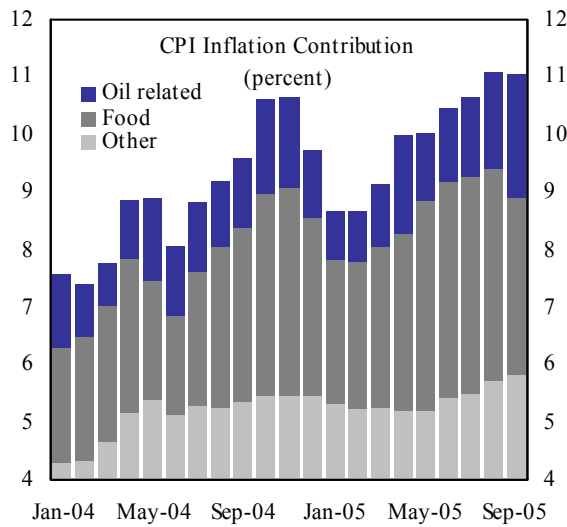

...reflecting a slowdown in financial services and construction.

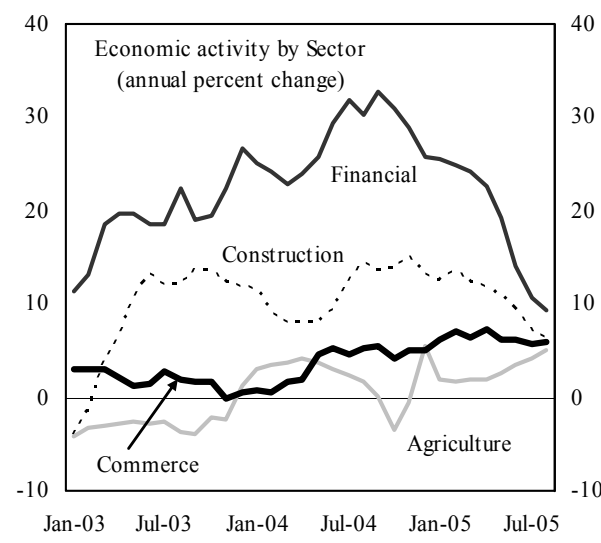

However, deposit growth has slowed somewhat

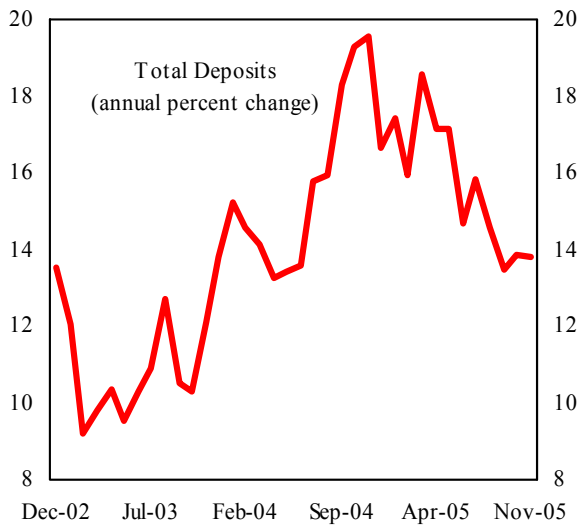

Real interest rates and interest differentials have fallen

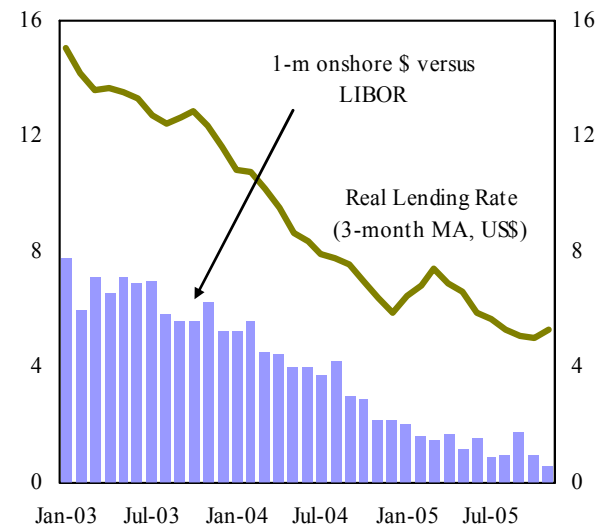

Source: Central Bank of Nicaragua. 
official financing. However, private investment and consumption growth remain buoyant, on the back of strong growth in credit and remittances, while imports remain robust. Separately, formal sector employment continues to rise.

9. Inflation has picked up, reflecting in part the oil shock, though core inflation has also increased. CPI inflation rose to 10.3 percent $y / y$ in October, while both non-oil related inflation and core inflation (excluding food and energy related prices) increased steadily. The prices of oil related components of CPI inflation, including oil, electricity and transport have risen significantly, in line with international petroleum prices.

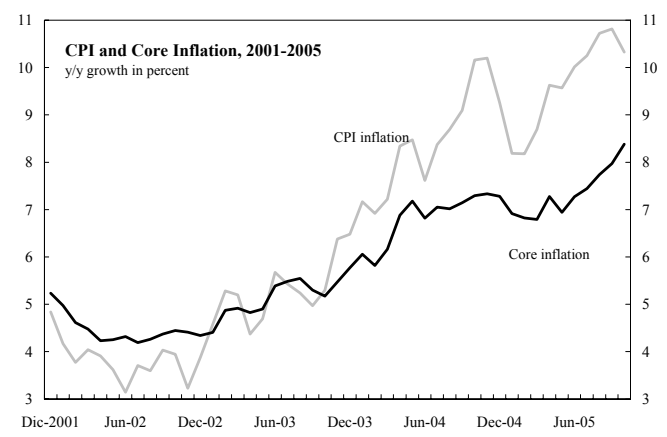

10. The authorities have taken steps to strengthen the fiscal policy framework following passage of the weakened 2005 budget (Figure 3). The executive's proposal for the 2005 budget targeted a 1.2 percentage point of GDP reduction in the CPS deficit relative to the expected 2004 outcome of 4.0 percent of GDP. However, the budget approved by the National Assembly implied instead an adjustment of only 0.6 percent of GDP, and included an increase in the total wage bill of some 21 percent. In response to this, the authorities have implemented revenue measures expected to yield about $1 / 2$ percent of GDP on a full year basis to offset the impact of the higher wage bill. This has supported continued strong revenue growth this year, which also reflects some improvements in tax administration and a surge in taxes on imports (Box 2).

\section{The CPS deficit is now expected to fall by more than $1 / 2$ percent of GDP in 2005 .}

Buoyant revenues combined with higher-than-originally-budgeted foreign grants, have facilitated approval of a revised central government budget consistent with a projected CPS deficit of 2.2 percent of GDP in 2005 while also finding room to increase capital spending. In this context, the deficit of the state electricity company is expected to rise as it is funding the bulk of the power subsidy granted this year because of delays in tariff adjustments (see $\mathbb{9 1 2}$ ). On the other hand, the CPS balance has been supported by the improved quasi-fiscal performance of the central bank reflecting in part lower interest costs (as it has continued to pay down expensive domestic debt and benefited from HIPC relief). In previous years, capital outlays have typically been higher-than-expected in the last quarter. This year, the authorities have required that foreign-financed project spending be tightly controlled by the ministry of finance and therefore feel the scope for unexpected outlays has been considerably lessened.

12. Power sector losses increased sharply in $\mathbf{2 0 0 5}$ as rates were not increased in line with rising fuel input costs (Box 3). Electricity tariffs paid by consumers were not adjusted during December 2003 through July 2005, creating losses at the electricity distributor, which are estimated to have reached over 0.6 percent of GDP in 2005. The regulator granted a tariff increase in July 2005, which was later stayed by the Supreme Court. Rolling blackouts during September drove political support for a solution, resulting in the regulator granting 
Figure 3. Fiscal Developments
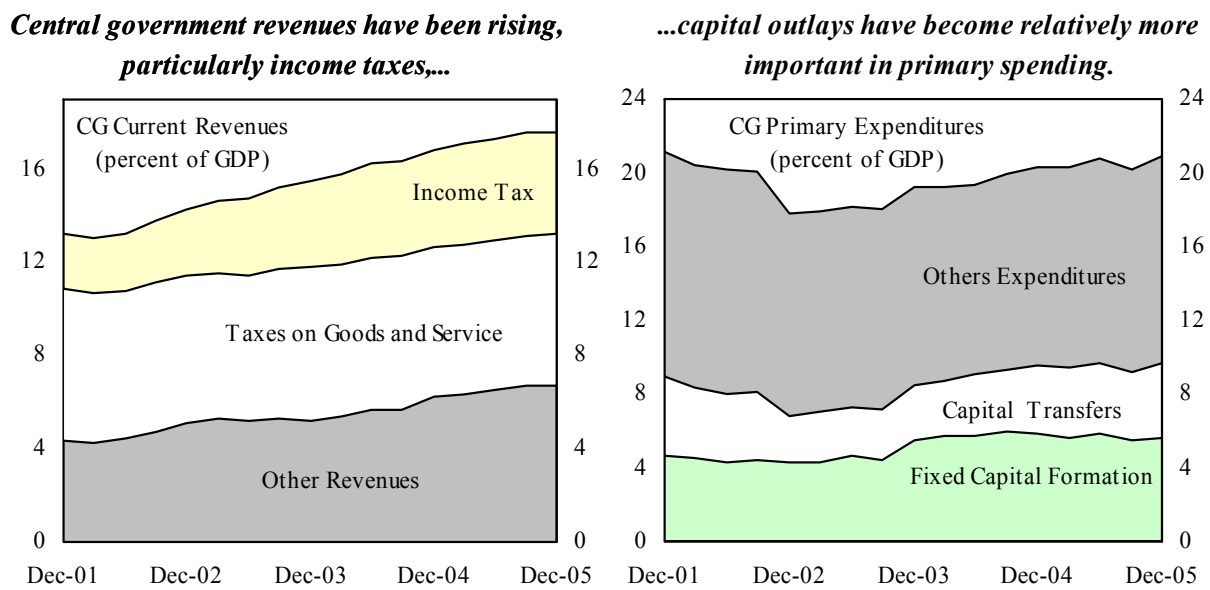

\section{The fiscal deficit has remained under control...}

...and the government has relied on concessional external financing to finance the deficit and repay costly domestic debt.
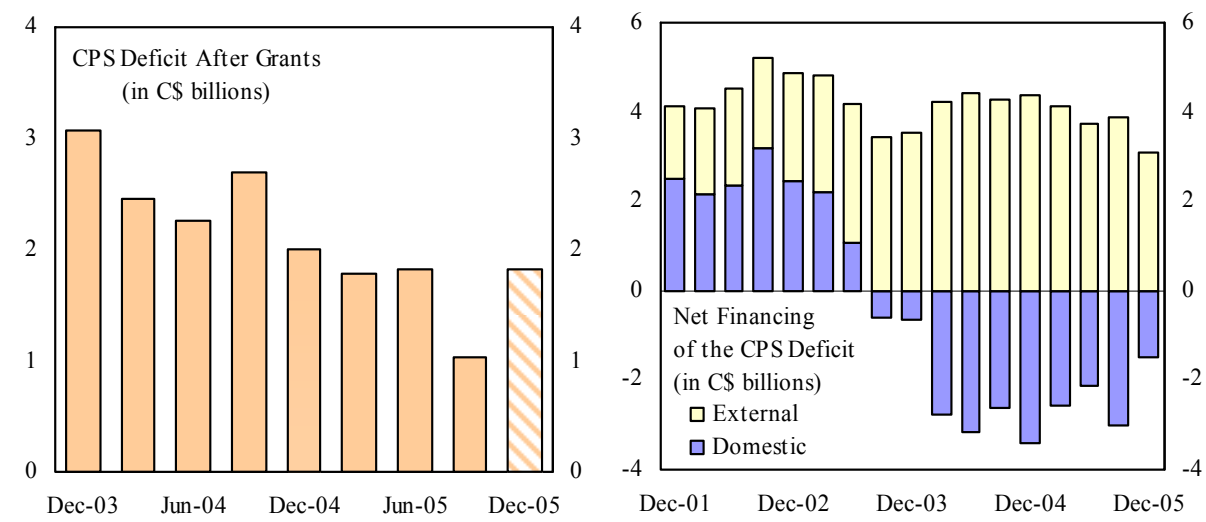

The execution of public investment has been at levels below the level of tied grant and loan inflows. have both helped, the public debt remains high.
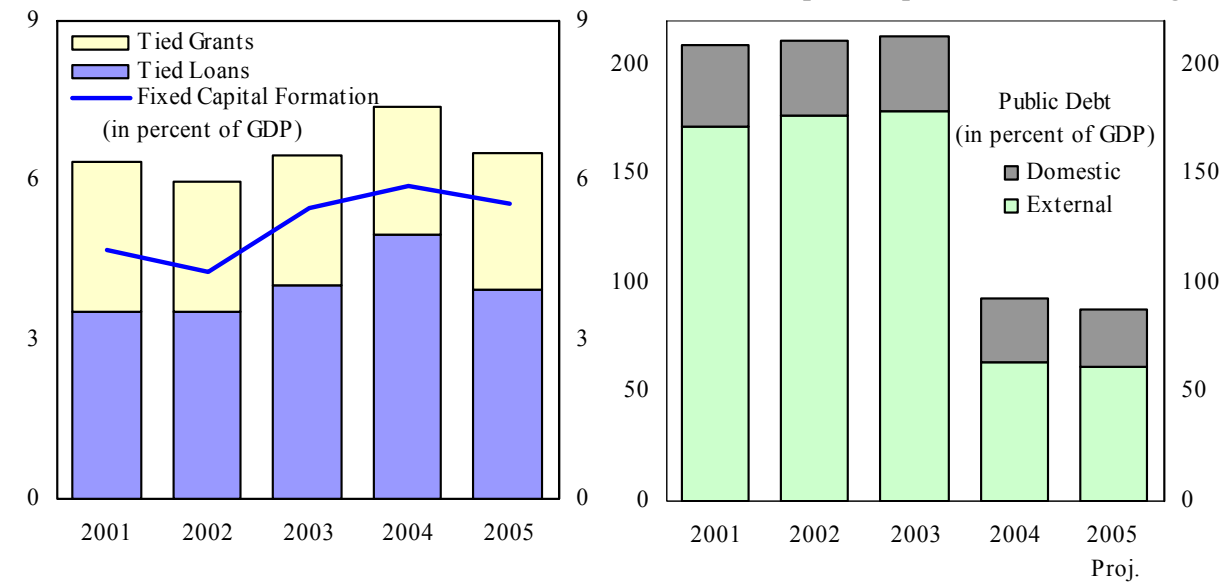

Source: Central Bank of Nicaragua. 


\section{Box 2. Trends in Tax Revenue}

Tax revenues have grown strongly in recent years, especially taxes on income and imports. Tax revenues as a share of GDP have increased by more than $3 \frac{1}{2}$ percentage points from 2001, reaching 16.9 percent of GDP by 2004. This reflects, in part, the impact of tax policy measures taken by the authorities during 2002-04 that are estimated to have yielded about one percent of GDP. Additional tax measures in 2005 are expected to yield about $1 / 2$ percent of GDP on annual basis. Furthermore, the tax base has grown strongly, with imports rising at an average yearly rate of $14 \frac{1}{2}$ percent in dollar terms during 2004-2005. Moreover, the internal tax administration (DGI) has been undertaking, starting in 2003, a modernization plan to strengthen its information and control systems, and reorganizing the large taxpayer unit (LTU).

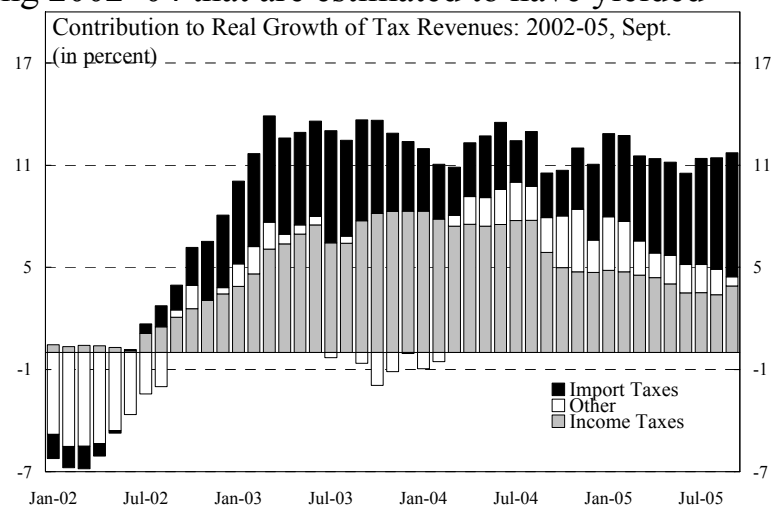
As a result, the percentage of stop-filers at the national level LTU has declined to under 1 percent from over 20 percent in 2003, while the ratio of taxpayers in arrears for the same group declined to 1.3 percent.

\section{However, it is unclear how long this rapid pace of revenue growth can be sustained.}

Growth in collections from the large taxpayers unit has slowed, in part as early gains from administrative improvements are being exhausted. Moreover, 90 percent of collections come from the top 1.3 percent of taxpayers, leaving overall performance vulnerable to factors affecting these few taxpayers. The high concentration of tax revenues in a few taxpayers also indicates that many taxpayers remain outside the tax net and/or could be underreporting their tax obligations.

Furthermore, the most dynamic taxes are

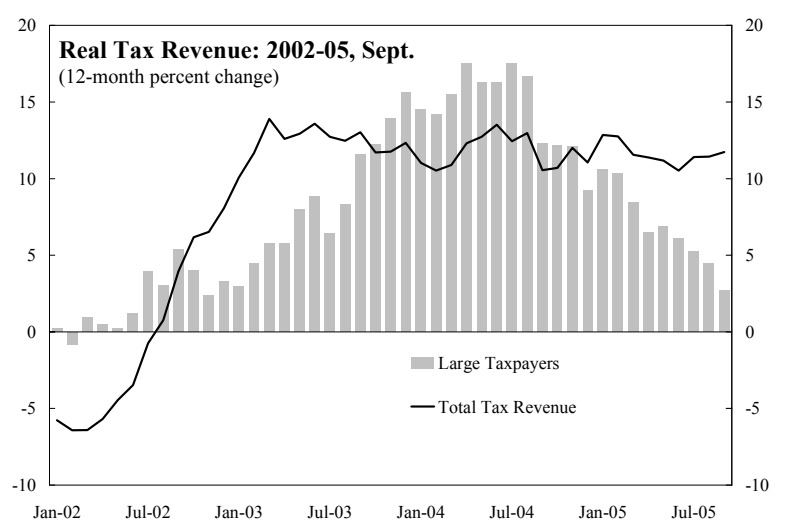
now on imports, but import growth is expected to slow to about 5-8 percent in the coming years. Additionally, the looming elections pose an additional, if hard to quantify, risk. During the last general election cycle in 2002, tax collections fell sharply (by over 1 percent of GDP), partly due to a slowdown in economic activity, but also reflecting the difficulty of tax enforcement in a politically charged environment. 


\section{Box 3. Electricity Sector in Nicaragua}

Over December 2003-June 2005, electricity tariffs were not increased in line with rising oil input prices. Final tariffs are regulated and had been reviewed (though not necessarily revised) once a year. However, prices charged by generators to the distribution company are market determined. Political infighting had created a leadership vacuum at the electricity regulator and tariffs had last been revised in 2003. As a result, distribution margins turned negative in late 2004 with rising oil prices (most electricity generation uses oil as its main input-hydro accounts for 20 percent of total production).

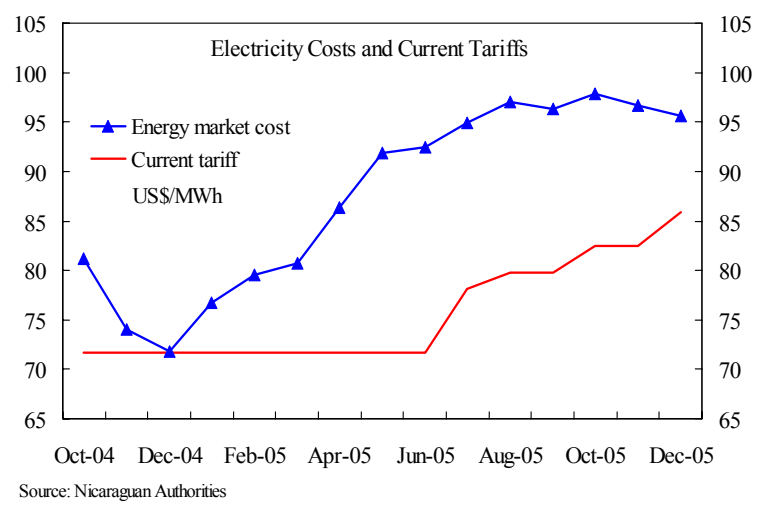

As a result, losses in the sector increased sharply, requiring a policy response. A one-time subsidy (0.6 percent of GDP) was granted in 2005 to the main private distributor to cover accumulated losses. The authorities also began implementing a plan combining rate increases and targeted subsidies. Tariffs increased by about 20 percent between July and December 2005. However, additional tariff increases, estimated by the authorities at about $6 \frac{1}{2}$ percent, are required to eliminate quasi-fiscal losses in the sector. The authorities plan to carry out this adjustment in increments by June 2006. In order to limit the impact on the poor, there has been no increase in prices for consumers using less than $150 \mathrm{KWH}$ per month, about 75 percent of all consumers. This subsidy will be financed by the projected additional value added tax revenues collected from charging some consumers higher tariffs. To stem future losses in the sector, an Energy Stability Law approved in September 2005 authorizes the regulator to make monthly tariff adjustments, on the basis of fluctuations in generation costs.

The energy sector will require significant new investment in the medium term. Power supply is not reliable, while distribution losses and production costs are among the highest in Central America. Nicaragua needs significant investment in reliable and low-cost generation capacity.
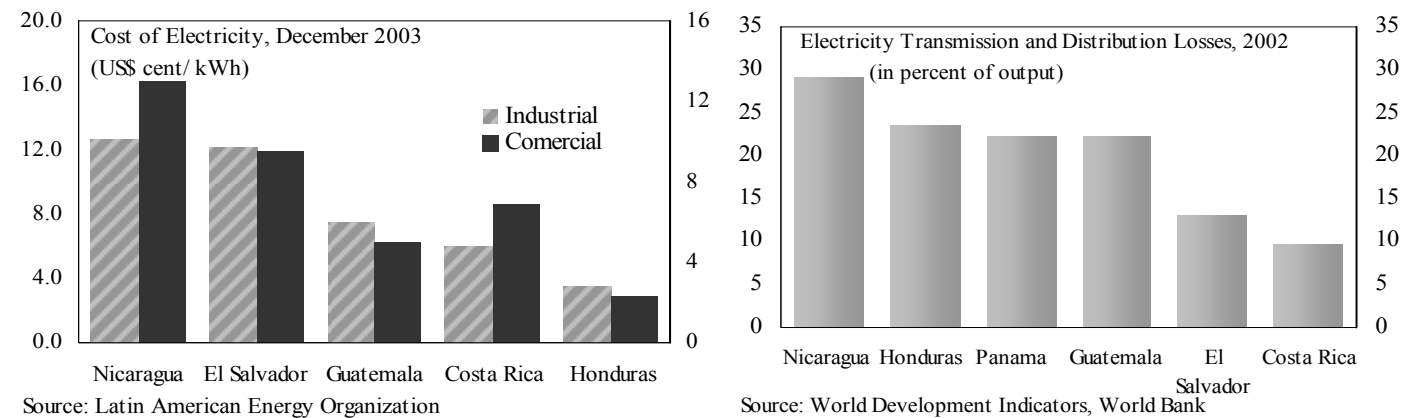

Reform of the regulatory framework is a sine qua non for attracting new investment and putting the sector on a sound financial footing. As a first step, reforms of the ESL to eliminate distortionary interventions will be needed. It will also be important to develop an independent regulator and introduce a transparent, rules-based pricing framework that allows investors a reasonable rate of return. The IDB and the World Bank are considering supporting further reforms in this area. 
tariff increases adding up to about 20 percent through December 2005, with the scope to have further tariff revisions granted under the new Energy Stability Law (ESL). The government has financed the sector's losses in 2005 through the central government budget $(0.2$ percent of the GDP) and indirectly through ENEL, the state-owned power company ( 0.4 percent of GDP), which condoned arrears accumulated by the distributor.

\section{Banking sector soundness indicators have improved, though credit has expanded} rapidly and risks remain from high levels of dollarization. Following recovery from the financial crisis of 2000-01, the sector has become highly profitable with pre-tax returns to average equity of about 35 percent in 2005. The non-performing loan ratio was 4.3 percent of all loans in 2005 with reported capital adequacy ratios at just over 14 percent. Bank deposits have grown strongly in recent years, supported by family remittances, though the pace has moderated in recent months, likely reflecting the slower economic activity and falling interest differentials. However, real credit has been growing rapidly at just under 20 percent in the last year. Moreover, the banking system is highly dollarized, and while the open foreign currency position does not appear large, underlying credit risk could be transformed as well into currency risk (Box 4).

\section{The sharp increase in the oil bill in recent years has been only partially offset by} strong remittances and exports (Figure 4). The external current account balance had been continuously strengthening since 1999, supported by gains in competitiveness, buoyant remittance flows (which at 11 percent of GDP were higher than net official financing in 2004), and the post-completion point reduction in interest payments. However, exports and remittances have slowed since early 2005 , reflecting weaker U.S. growth, while rising world oil prices put pressure on total imports. Indeed, the oil bill is projected to increase to almost $12^{1 / 2}$ percent of GDP in 2005, up from 6 $1 / 2$ percent of GDP in 2002 (Box 5 discusses the broader impact of elevated oil prices). As a result, the current account deficit is estimated to have reached about 17 percent of GDP in 2005. Combined with delays in donor disbursements (arising from political uncertainties and the stalled reform agenda), the increase in net international reserves was projected to be held to US\$15 million in 2005.

15. Progress has been made on implementation of the PRSP. Since the adoption of Nicaragua's first PRSP in 2001, poverty reducing spending has increased from about 10 percent of GDP in 2002 to $13^{1} \frac{1}{2}$ percent of GDP projected for 2005 . The positive effects of the PRSP implementation are reflected in improved indicators in the education and water sectors, where PRSP-I targets on primary school enrollment and water coverage were exceeded in 2003 and 2004. However, implementation of the PRSP-I has been more mixed in the health sector where targets have not been achieved, and the coverage of vaccination programs has been weak. 


\section{Box 4. Financial System Vulnerability}

Nicaragua has one of the highest levels of dollarization in Latin America. The financial system is relatively small with foreign currency denominated deposits accounting for over 80 percent of total deposits. The elevated level of dollarization reflects continued low levels of policy credibility as well as some hysteresis in the aftermath of past high inflation episodes.

\section{The financial system is also exposed to} the risk of currency mismatches. Banks

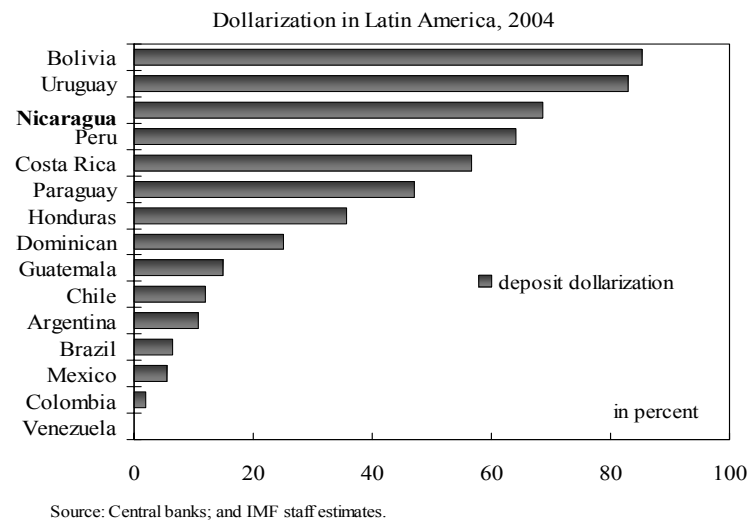
generally maintain a balanced foreign currency book, with small net-open positions in some months. However, a significant part of bank assets are held domestically in the form of dollar denominated loans to the private sector and it is unclear how much of this exposure is naturally hedged. Consumer and commercial loans comprise the largest share (28.5 and 26.8 percent respectively). Indeed, credit growth has been particularly brisk to the construction and real estate sectors. Further, banks' direct exposure to dollarlinked bonds issued by the public sector (including the central bank) is also sizeable. Credit events linked to large exchange rate movements could transform this exposure into a sizeable currency

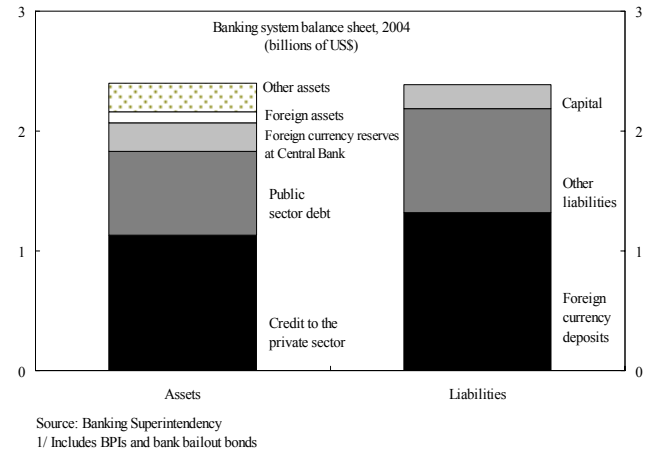
risk. Against this, banks are required to maintain $16 \frac{1}{4}$ percent of their total foreign currency assets as reserves with the central bank. Available data suggest that banks maintain additional foreign currency assets offshore with BIS reporting banks. 
Figure 4. External Developments

Exports growth remained robust, but import growth has been even higher, in part reflecting the oil price shock.

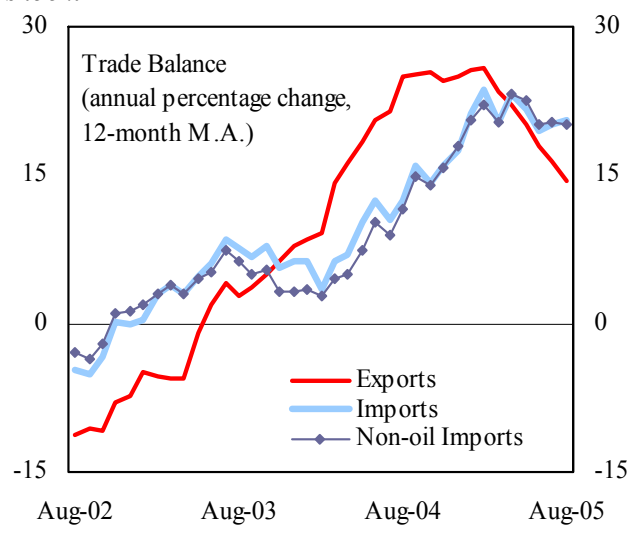

... despite continued buoyant remittances.

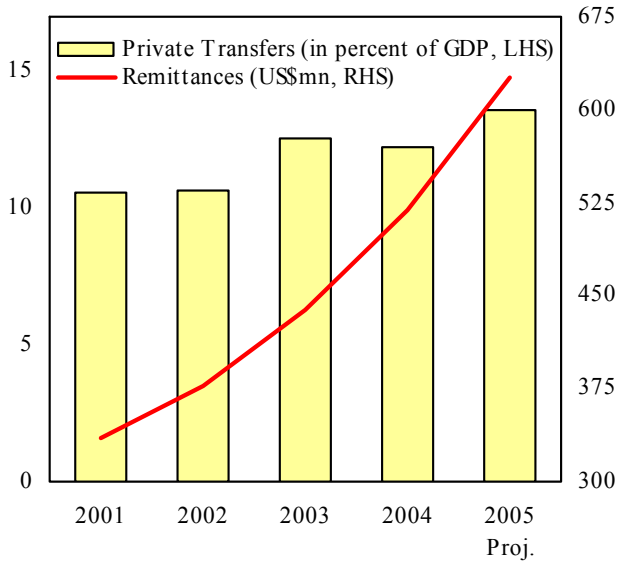

However, reserve coverage of imports has not increased...

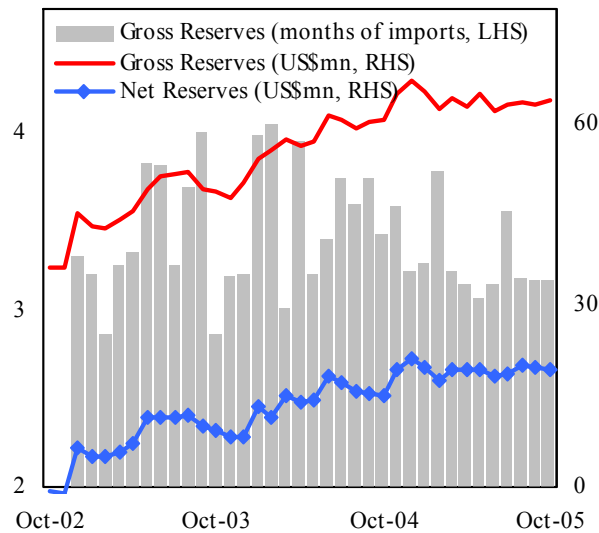

As a result the current account, which improved in 2004 as a share of GDP, deteriorated in 2005...

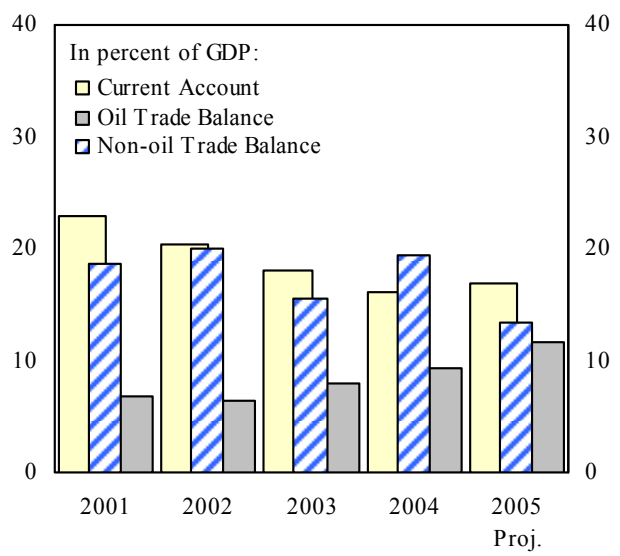

FDI remained robust.

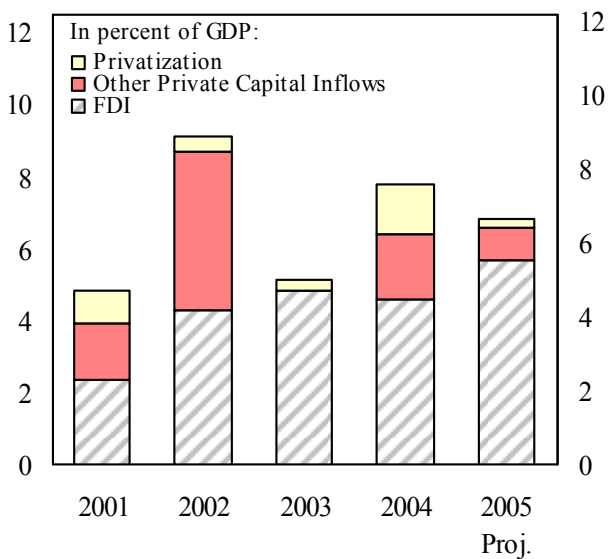

...reflecting, in part, the decline in donor

financing.

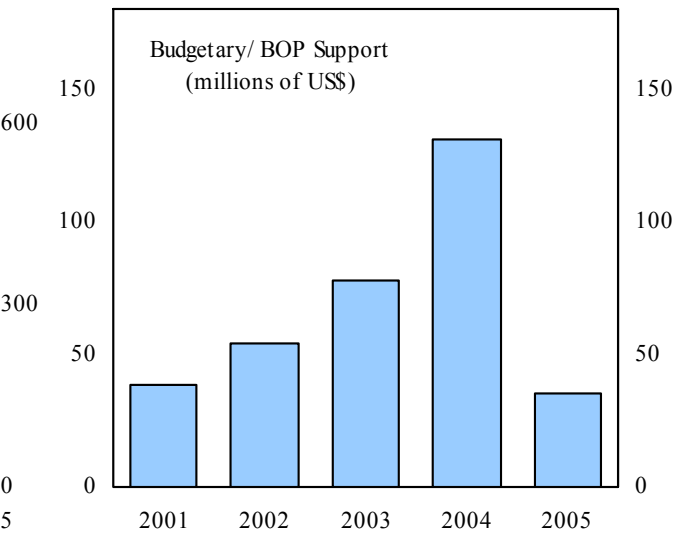

Source: Central Bank of Nicaragua and Information Notice System. 


\section{Box 5. Impact of Higher Oil Prices on the Nicaraguan Economy}

Nicaragua is a relatively energy intensive economy, including in comparison to other countries in the region. The increase in international oil prices has therefore led to a reduction in the rate of growth of output and to a near doubling in the oil bill since 2002.
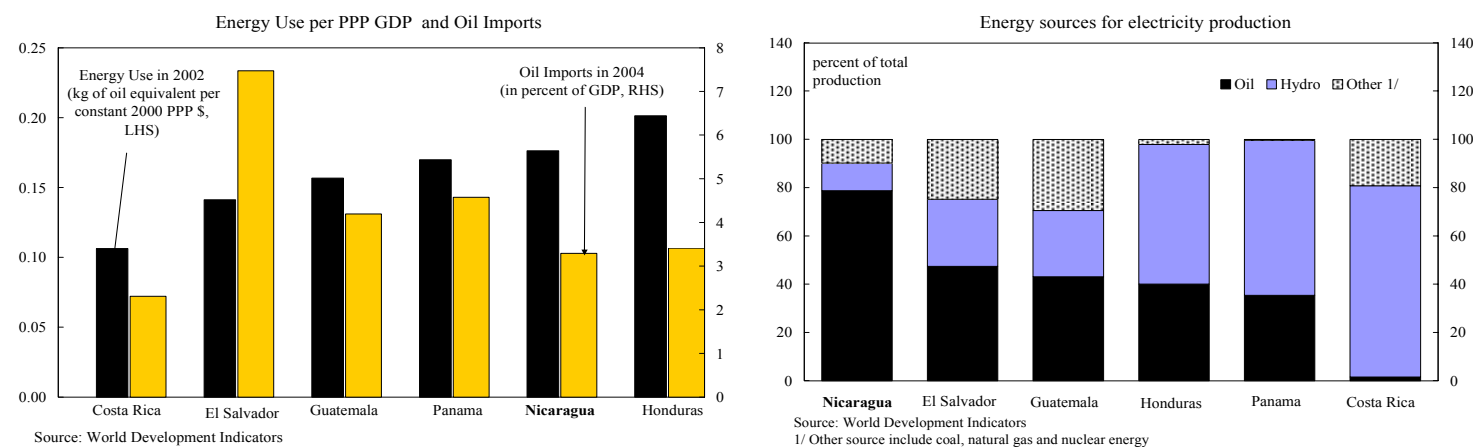

One of the factors driving the large impact of the oil shock, relative to other countries in the region, is the important role of oil-based generation in the total production of electricity. Oil fuelled plants account for about 80 percent of total electricity produced in Nicaragua.

Pass-through of higher oil prices to domestic gasoline prices has been complete. Domestic gasoline prices are not regulated, and have moved broadly in line with US retail prices. This has contributed to the pick-up in headline inflation, although non-oil inflation has also increased, indicative of second round effects and possible demand pressures. However, the increase in oil prices has not yet been completely passed through to final electricity prices, which are regulated (see Box 3 on the power sector).

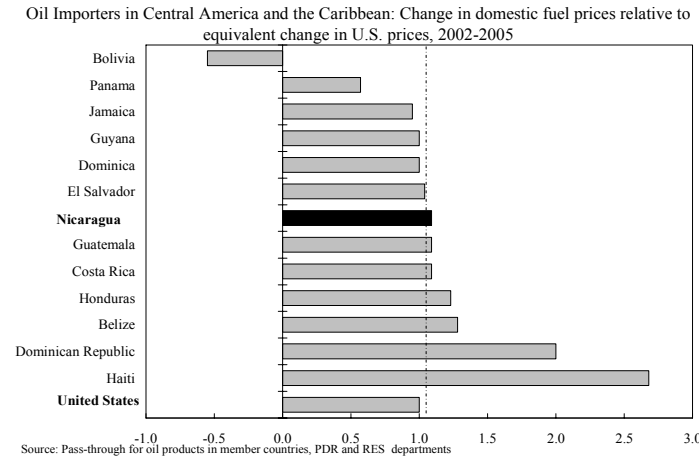

\begin{tabular}{|c|c|c|c|c|}
\hline & \multicolumn{2}{|c|}{ Growth (percent change) } & \multicolumn{2}{|c|}{ Inflation (percent change ) } \\
\hline & 2005 & 2006 & 2005 & 2006 \\
\hline Central America & -0.3 & -0.6 & 1.1 & 2.3 \\
\hline Costa Rica & -0.4 & -0.6 & 2.1 & 3.6 \\
\hline El Salvador & -0.6 & -1.5 & 1.3 & 2.5 \\
\hline Guatemala & -0.1 & -0.2 & 0.6 & 1.5 \\
\hline Honduras & -0.1 & -0.3 & 1.1 & 3.4 \\
\hline Nicaragua & -1.1 & -1.0 & 1.0 & 2.5 \\
\hline Panama & -0.1 & -0.3 & 0.5 & 0.5 \\
\hline \multicolumn{5}{|l|}{ Memo items: } \\
\hline Oil Price (baseline) & & & 46.5 & 43.8 \\
\hline Oil Price increase (in percent) & & & 17 & 40 \\
\hline
\end{tabular}

Higher oil prices have had a relatively large impact on growth and inflation in Nicaragua compared to many other countries in Central America. This reflects the country's relatively high energy intensity of output and large oil import bill in 2005. Estimates of the impact of higher oil prices on Central American countries prepared by WHD staff are shown in the adjoining table. The analysis assesses the impact of higher baseline oil prices in 2005-06 (in the October 2005 WEO relative to the May WEO exercise) on growth and inflation in the region. 


\section{OUTLOOK AND VULNERABILITIES}

16. The near term outlook contains important risks. Growth in 2006 is expected to moderate, reflecting the impact of higher oil prices and some slowdown in external demand. Inflation remained elevated in 2005 and, while the path of oil prices remains a key uncertainty, there is likely to be a need to tighten liquidity conditions to bring inflation down further in 2006. Moreover, further electricity tariff increases in the pipeline will continue to pressure headline inflation. Core inflation will likely continue rising in early 2006 before the second-round effects of the oil shock start to wane. The fiscal outlook for 2006 will hinge on expenditure restraint. Political uncertainty in the run-up to the November 2006 presidential and legislative elections, and increases in election-related expenditures remain key risks.

\section{Important vulnerabilities arise} from weak balance sheets and institutions, and the political situation. The large trade deficit and elevated level of debt imply a heavy reliance on transfers, both private and official. Furthermore, the financial sector is highly dollarized and holds high levels of public debt. Moreover, experience has shown that confidence may be adversely affected in the run-up to elections. Further, the weakened regulatory framework for utilities

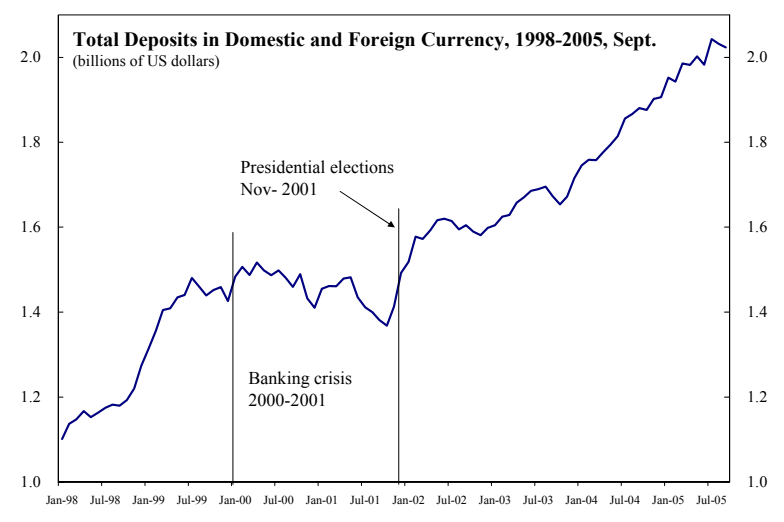
and telecoms could hinder needed investment and raise fiscal risks.

\section{Medium-term prospects hinge on measures to boost investment and productivity} while reducing large existing imbalances. Reducing imbalances on a sustained basis will require continued fiscal consolidation and structural reforms aimed at boosting economic growth. Political uncertainty and an unstable regulatory environment are proving obstacles to investment, growth, and poverty reduction. Strengthening the investment climate and competitiveness will be crucial for boosting growth, as will taking full advantage of the opportunities offered by CAFTA-DR . Nicaragua's external competitiveness has improved in recent years (Box 6), but the need to ensure further improvements as a result of

\footnotetext{
${ }^{3}$ Issues related to the implications of CAFTA-DR for Nicaragua are discussed in Chapter 1 of the accompanying Selected Issues Papers. CAFTA-DR is expected to enhance the growth performance of the whole Central American region including Nicaragua. The main effects are likely to be a rapid increase in trade flows with the United States, increased product diversification in the traded sector, a pickup in FDI inflows, and reduced macroeconomic volatility. Of all the signatory countries, Nicaragua is expected to face the smallest fiscal impact, mainly owing to a favorable schedule of tariff reductions negotiated with the United States.
} 


\section{Box 6. Competitiveness and Business Environment}

Nicaragua's external competitiveness has improved in recent years, but gains remain fragile. The real exchange rate (REER) has depreciated since 2001, while the tradable sector has grown quickly (reflecting both manufacturing and commodity exports), driving a reduction in the current account deficit. Nevertheless, debt-creating external financing was still equivalent to about 8 percent of GDP in 2004. Moreover, the REER has been flat in recent months, and the non-oil trade balance is expected to deteriorate slightly in 2005 .
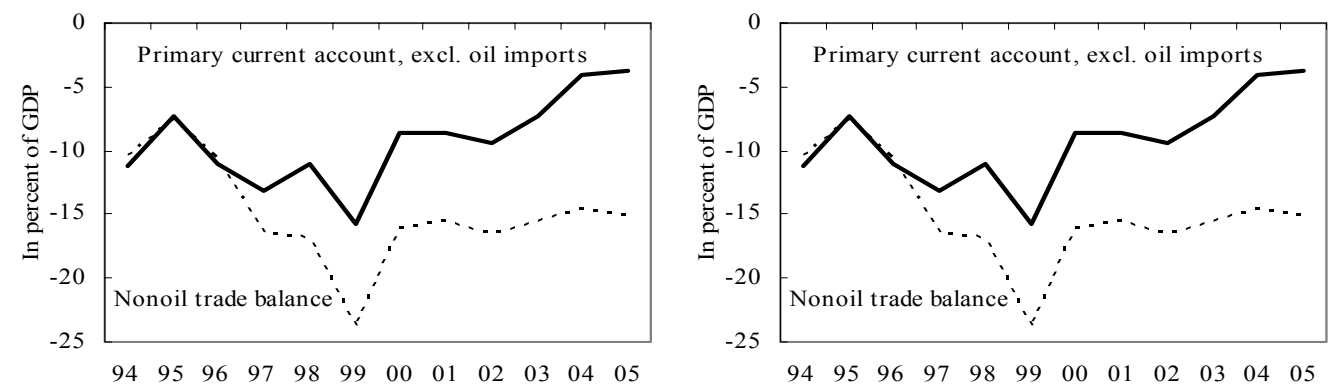

Nicaragua's appears to be in a strong competitive position with regards to other CAFTA-DR countries. Nicaragua has enjoyed the strongest rate of growth of the maquila sector in the region, indicating the investors' relative preference for that country. Similarly, Nicaragua has been the only country in the region to broadly maintain market share in the US in competition with Chinese exports, including in textile products.

U.S imports by origin, 2003-05 (growth rates in percent)
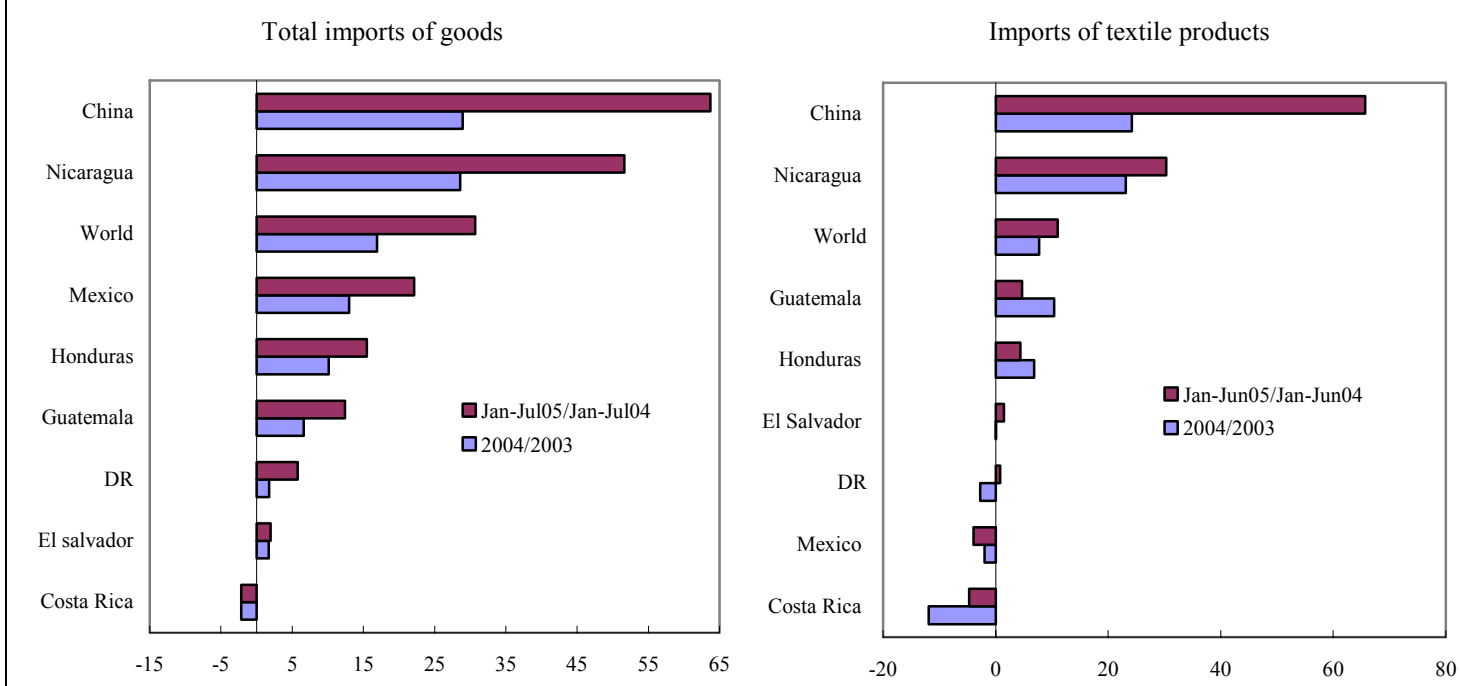


\section{Box 6. Competitiveness and Business Environment (continued)}

Much remains to be done to improve Nicaragua's business environment. Governance, infrastructure, and access to credit are key concerns in this respect. The recent World Bank Investment Climate Survey looks at indicators such as security, regulation, taxation, finance, infrastructure, and labor markets. Using emerging markets as a benchmark, Nicaragua lags behind in all areas, except labor and taxation. More than half of Nicaraguan entrepreneurs perceive corruption and regulatory uncertainty as the major impediments to investment. Financing difficulties, the costs of starting up business, and weaknesses in infrastructure, particularly inadequate power services, are also ranked among the highest impediments to growth. Moreover, the World Economic Forum survey, ranks Nicaragua's competitiveness among the worst of the region.

Survey-based Indicators of Competitiveness

\begin{tabular}{llllll}
\hline Nicaragua $^{1 /}$ & Costa Rica & DR & El Salvador & Guat. & Honduras \\
\hline
\end{tabular}

World Economic Forum Competitiveness Indicator (2005)

$\begin{array}{lllllll}99 & (5) & 97 & 102 & 56 & 64 & 93\end{array}$

World Bank Indicators on the Ease of Doing Business (Rank Among All Countries), 2005

$\begin{array}{lrrrrrrr}\text { Doing Business } & \mathbf{5 9} & \mathbf{( 1 )} & 89 & 103 & 76 & 109 & 112 \\ \text { Starting a Business } & \mathbf{6 5} & \mathbf{( 1 )} & 83 & 101 & 127 & 120 & 129 \\ \text { Dealing with Licenses } & 72 & (3) & 43 & 33 & 75 & 142 & 79 \\ \text { Hiring and Firing } & 80 & (3) & 72 & 100 & 88 & 92 & 56 \\ \text { Registering Property } & 110 & (5) & 38 & 116 & 45 & 61 & 78 \\ \text { Getting Credit } & 71 & (6) & 33 & 47 & 34 & 49 & 50 \\ \text { Protecting Investors } & \mathbf{7 2} & \mathbf{( 1 )} & 134 & 112 & 81 & 122 & 129 \\ \text { Paying Taxes } & 130 & (6) & 129 & 124 & 82 & 125 & 113 \\ \text { Trading Across Borders } & 50 & (2) & 88 & 32 & 113 & 51 & 119 \\ \text { Enforcing Contracts } & \mathbf{2 2} & \mathbf{( 1 )} & 141 & 130 & 53 & 117 & 136 \\ \text { Closing a Business } & \mathbf{5 5} & \mathbf{( 1 )} & 99 & 131 & 64 & 86 & 84 \\ \text { Average rank } & \mathbf{7 1} & \mathbf{( 1 )} & 86 & 94 & 76 & 98 & 99\end{array}$

1/ Number in italics indicates the rank among DR-CAFTA countries. 
productivity growth highlights the importance of wage restraint going forward, especially in the public sector.

\section{The authorities have prepared a revised poverty reduction strategy that re-} asserts their focus on achievement of the millennium development goals (MDGs). The revised PRSP-II builds on the PRSP-I, with key objectives including poverty reduction and achievement of the MDG's through economic growth, employment generation, increased investment and export promotion. Additional strategic areas emphasized in the PRSP-II include, human capital development and social protection, infrastructure development, good governance and state reforms. Implementation of the strategy laid out in the PRSP-II will remain a key challenge and it will be important to identify clearly the risks to the strategy to help mobilize domestic support for the agenda. Moreover, it will be important to discuss in the PRSP-II progress report how resources from MDRI debt relief would be used. At this point, achievement of the MDGs remains some way off (Table 15). In this context, a key concern is the need for further reforms of the fiscal framework to preserve the space for increasing investment to achieve the MDGs.

\section{The staff's medium-term baseline scenario assumes that strong reforms will} support growth and poverty reduction. Continuing fiscal reforms and sound macroeconomic policies should facilitate higher productivity of public investment and fiscal consolidation (especially reducing domestic debt). Meanwhile successful regional integration could drive greater FDI and strong growth of the tradable sector, coupled with higher remittances, gradually reducing the need for additional foreign savings and grants. All told, these would facilitate higher growth and poverty reduction with a gradual reduction of imbalances. The debt sustainability analysis (DSA) prepared by the staff (Appendix V) shows that the level of both external and domestic debt would continue to fall gradually over the medium term in the baseline, even under most shock scenarios. Gross financing requirements are expected to remain manageable and allow a gradual reduction in Nicaragua's dependence on development assistance. ${ }^{4}$ Nonetheless, debt levels would remain close to key vulnerability thresholds for several years, underscoring the need for steadfast adherence to a prudent macroeconomic consolidation program.

\section{However, in a weak policy alternative scenario, imbalances would increase}

(Figure 5). FDI, export and productivity growth would stagnate and maintaining monetary control would grow increasingly difficult. Growing rigidities in public expenditures would weaken fiscal performance driving debt levels up. Given constraints on external commercial borrowing, as well as some likely diminution of aid flows in such a scenario, the bulk of

\footnotetext{
${ }^{4}$ The DSA also includes a scenario factoring in the impact of the Multilateral Debt Reduction Initiative. Nicaragua's debt to the Fund and World Bank that would be subject to reduction amounts to about 8 percent of GDP in NPV terms ( $1 / 4$ of external debt in NPV terms). Debt service on these obligations is projected at US\$15 million in 2006.
} 
these increased imbalances would need to be financed domestically. This would drive up interest rates and the level of domestic debt, crowding out private investment and further reducing potential output growth. Viewed in the context of the LIC-DSA exercise (Appendix V), debt levels remain very sensitive to shocks to key underlying macro parameters.

\section{Policy Discussions ANd Program for 2006}

\section{A. Fiscal Policy}

\section{The fiscal strategy of the PRGF supported program has focused on bringing} down debt levels while creating room for poverty reducing spending. Key elements have included boosting revenues, reducing non-development expenditures, and strengthening the institutional framework. The medium-term framework targets about a $1 \frac{1}{2}$ percentage point of GDP reduction in the CPS deficit (after grants) to 0.6 percent of GDP during 2005-10, with gradually paced adjustment made possible by the continued availability of high levels of grants and other concessional finance. Achieving this adjustment will require continued public wage restraint, achievement of fiscal savings from effective decentralization, and continued efforts to strengthen tax administration. Debt levels would continue to decline, particularly for domestic debt, and debt service levels remain manageable, especially reflecting the high level of concessionality and debt relief.

\section{The budget for $\mathbf{2 0 0 6}$ approved by the assembly targets an underlying fiscal} adjustment in the election year. The budget targets an unchanged central government deficit after grants, projected to be 1.7 percent of GDP in both 2005 and 2006. However, the 2006 budget includes one-time expenditures of 0.9 percent of GDP for administering the 2006 elections as well as constitutionally mandated transfers to political parties for campaign financing. As such, the budget implies an underlying fiscal adjustment, including planned permanent savings of $1 / 2$ percent of GDP from the reduction of capital spending on municipalities. The CPS deficit is projected to be 2.2 percent of GDP in both 2005 and 2006. The programmed fiscal stance will be an important support for maintaining a stable financial framework in the election year and provide cover against possible expenditure risks. Looking ahead, the need for continued underlying adjustment is underscored by the still high public debt levels, which are expected to skirt close to the LIC-DSA's risk thresholds for the next several years (even including additional debt relief from the MDRI).

\section{The room for development spending is constrained by large mandatory transfers} and the high election costs. Revenues in 2006 are projected to stay unchanged as a share of GDP, with upside potential reflecting the strong performance in 2005 offset by downside uncertainties on tax administration arising in the run-up to the elections. To stay within the 
Figure 5. Alternative Medium-Term Macroeconomic Outlook
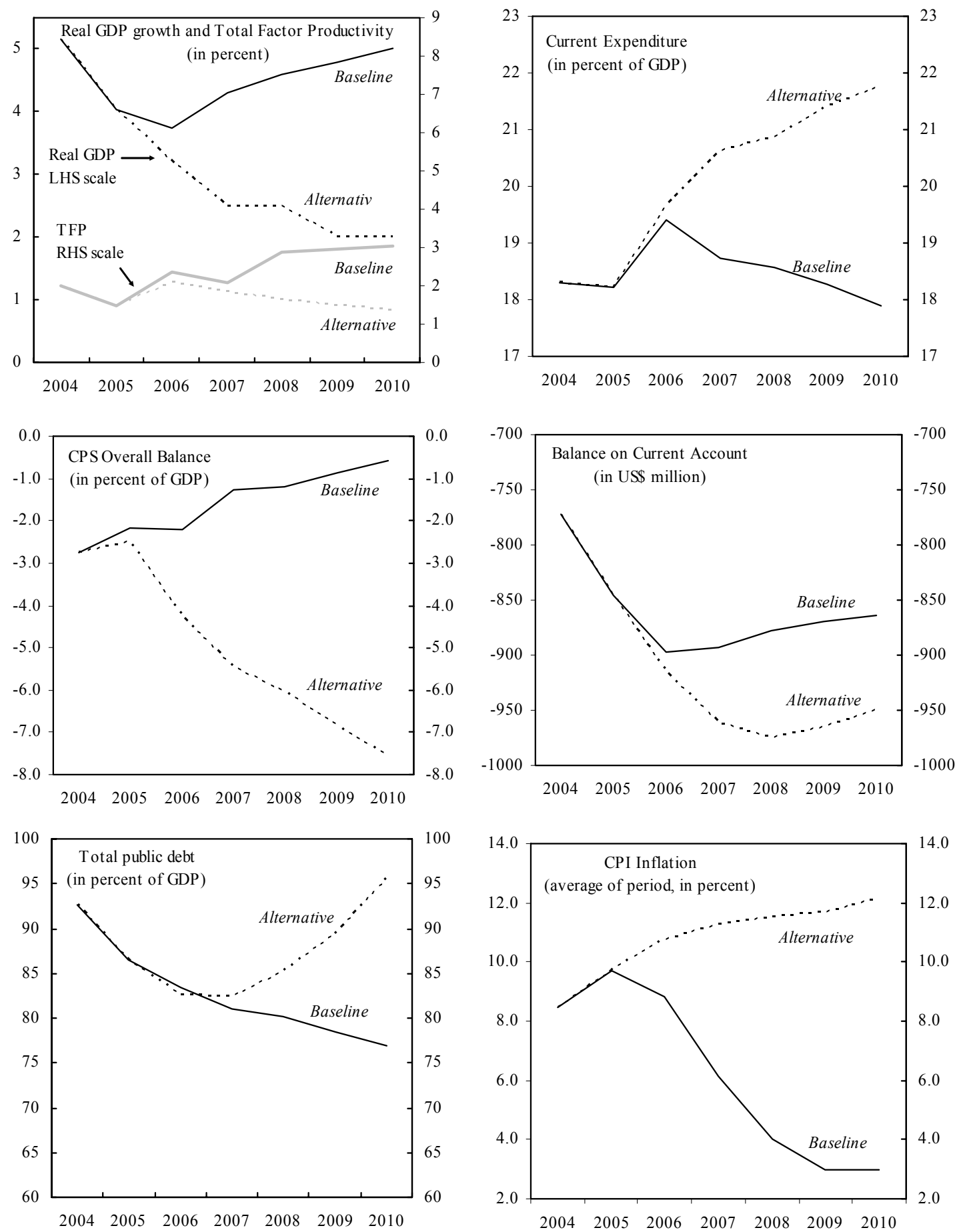

Source: Fund staff estimates 
overall expenditure ceilings, the budget builds in a reduction in capital spending of 1.5 percent of GDP, including on municipalities in line with the authorities' commitment to neutralize the fiscal impact of decentralization (0.5 percent of GDP). Additional fiscal space is provided by the somewhat lower public sector wage bill in the budget (0.2 percent of GDP lower than in 2005) as well as that electricity subsidies granted in 2005 (0.2 percent of GDP) are not expected to be repeated in 2006. However, the high election-

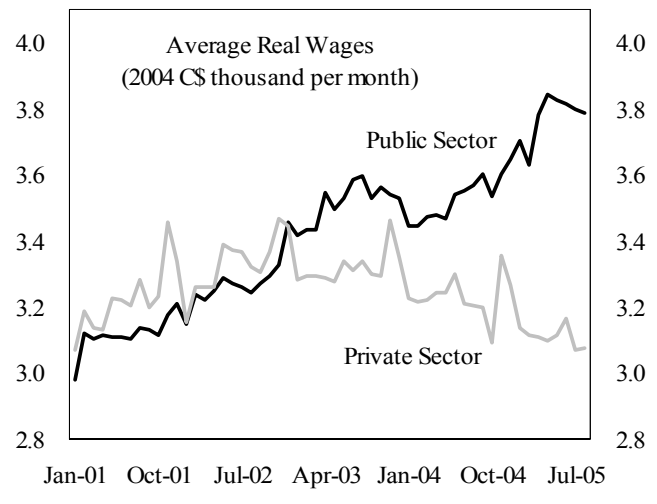
related costs and growing size of other constitutionally mandated transfers have squeezed the budget. ${ }^{5}$ Overall, the authorities believe that poverty-reducing spending in the 2006 budget will remain broadly unchanged relative to 2005 at about $12 \frac{1 / 2}{2}$ percent of GDP.

25. Public sector wages have grown rapidly in recent years. The wage bill, broadly defined, is now approaching as much as $8 \frac{1}{2}$ percent of GDP, at the high end of the distribution for Latin America. ${ }^{6}$ Available data suggest that public wages have risen well above private wages in real terms and there is a concern that continuation of this trend risks setting off a wage-price spiral and undermining competitiveness. In this context, rapid growth in the 2005 budgetary wage bill was a key issue delaying completion of the program review. Looking ahead, the mission stressed that ensuring that the wage bill rises no more than anticipated inflation would be crucial, and worked with the authorities to develop a measure of the central government wage bill that could be monitored and controlled as a new performance criterion under the program (MEFP $\mid 5)^{7}$

\section{The authorities are seeking to contain growth of the public sector wage bill in} line with expected inflation. Depending on the definition used, the wage bill in the budget proposed by the authorities was estimated to rise between $0.3-1.1$ percent $y / y$ in real terms as compared with the staff's recommended target of zero real growth. ${ }^{8}$ On top of this, higher

\footnotetext{
${ }^{5}$ Earmarked transfers to universities and the judiciary are set to grow by 0.3 percentage points of GDP in 2006 relative to the previous year.
}

${ }^{6}$ Chapter 2 of the accompanying Selected Issues Papers discusses issues regarding public sector wages, including how these compare with the private sector.

${ }^{7}$ Finding ways to measure the broader budgetary wage bill to be monitored under the program was a key topic for discussion with the authorities as spending on compensation of employees is much larger than wages and salaries reported in the economic classification of the budget (the latter accounted for about 4 percent of GDP in 2005).

${ }^{8}$ A broad definition of public sector wage expenditures that can be identified ex ante in the budget would rise by 0.1 percent $y / y$ in real terms. A narrower definition of the wage bill that 
spending proposed by the assembly would have increased wage bill growth to about 1.8-2.8 percent $y / y$ in real terms. Accordingly, the authorities took measures to bring the real wage bill growth implied by the budget passed by the assembly back down between 0.1-0.9 percent $y / y$. Corrective actions to keep the wage bill in check taken by the authorities include: (i) lowering compensation growth and eliminating vacancies in a number of government agencies; (ii) lowering wage payments to consultants under donor-funded projects (recorded under capital expenditures), and (iii) closing the defunct pension supervisory body. The mission cautioned with regards to cutting foreign funded consultants without careful study and coordination with donors. The authorities noted that there were large and well-known inefficiencies in this spending, which were, moreover, loan financedWorld Bank staff concurred with this assessment.

27. Electricity tariffs were increased by a cumulative 20 percent in 2005 , completing a key prior action for the program. In the absence of rate adjustments, quasi-fiscal losses had been estimated to reach at least 1 percent of GDP. The authorities want to minimize the social impact by gradually phasing in further rate increases. While clearly needed, their exact magnitude will depend on movements in international oil prices and other factors. The energy regulator has estimated that with present international prices, additional rate increases of $6 \frac{1}{2}$ percent during January-June 2006, should eliminate quasi-fiscal losses in the sector. The authorities have agreed to increase rates as needed by mid-2006 to eliminate losses, and the regulator will introduce an automatic adjustment mechanism in mid-2006 once the current round of rate adjustments has been completed.

\section{B. Monetary and Exchange Rate Policy}

\section{The case for tightening monetary policy was discussed in the context of high} inflation and strong credit growth. There was agreement that supply shocks were important drivers of both headline and core inflation. However, staff expressed a concern that rising core inflation also reflected second-round effects and demand pressures including from the impact of the public wage hikes and high credit growth. The authorities explained recent rapid credit growth in part as reflecting base effects after the banking crisis in 2000-01 that led to steep falls in credit during 2002-03, as well as normal financial deepening. The staff noted that real base money growth has been brisk while real lending rates and dollar interest differentials have fallen with credit now higher than pre-banking crisis levels, and in line with other Latin American countries.

29. The authorities intend to tighten liquidity conditions. While the independence of monetary policy is constrained by the crawling peg exchange rate, there is some scope for the

can be monitored ex post and controlled for the program performance criterion (accounting for about 90 percent of the wider budgetary wage bill) would rise by 0.9 percent $y / y$ in real terms. Further discussion of wage bill definitions is presented in Chapter 2 of the accompanying Selected Issues Paper. 
central bank to contain demand pressures by reducing liquidity in the system, given that capital mobility is not complete.

Accordingly, the program builds in action by the central bank to absorb liquidity through open market operations ${ }^{9}$ consistent with a program objective of significant reserve accumulation in the first half of the year, as well as concerns on inflation and maintaining stability (MEFP 97). However, the need for substantial monetary measures has been

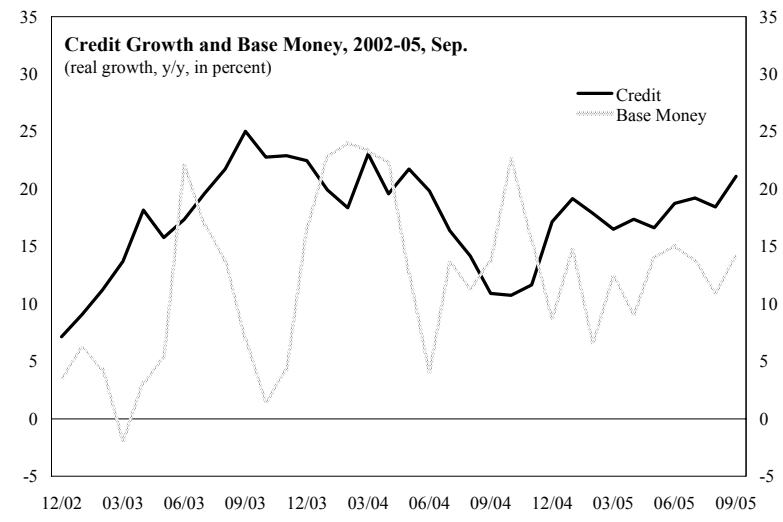
reduced by the supportive fiscal policy stance, which allows for a reduction in central bank credit to the government. For 2006, the program targets an increase in adjusted NIR of the central bank of US $\$ 85$ million, facilitated in part by substantial expected donor financing.

\section{The authorities have decided to keep the rate of crawl of the exchange rate peg} unchanged at 5 percent in 2006. In recent years, the authorities have gradually slowed the rate of crawl to reduce inflation (pass through is very high). However, they believe that lowering the crawl in an election year may not be credible and, in the face of the oil shock, could risk a loss of competitiveness. Adding in election-related uncertainties, the authorities and the mission agreed with keeping the rate of crawl unchanged in 2006 to buffer shocks.

\section{The authorities and staff discussed the pre-}

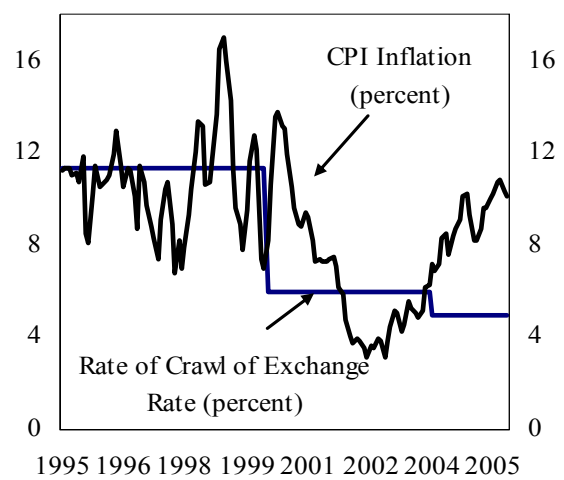

conditions for moving to a more flexible exchange regime over the medium term. There was agreement that the crawl has served well to anchor inflation expectations, but the staff noted that it reduces flexibility in dealing with unanticipated shocks, with vulnerabilities heightened in the context of a highly dollarized small open economy. The authorities and staff agreed that strengthening the regulatory framework and improving balance sheets (public and financial sectors), and better developing open market operations, will be among

\footnotetext{
${ }^{9}$ The central bank's options for tightening liquidity to banks are constrained by several factors, including the fact that most credit is dollar denominated. The mission discussed alternatives including increasing reserve requirements on both cordoba and dollar deposits (the latter could discourage dollarization of the banking system). However, the authorities and the mission were concerned about the distortionary impact of increasing reserve requirements and thus opted on balance to focus on open market operations.
} 
the preconditions for eventually moving to a more flexible exchange rate regime. ${ }^{10}$ Building on recent important financial sector reforms (\$39) will be crucial to facilitate this transition.

\section{Structural Agenda}

\section{Structural Fiscal Reforms}

32. Introducing a credible fiscal responsibility law (FRL) is a key post-election goal, and developing a road-map for moving in this direction is crucial. ${ }^{11}$ Approval of an FRL, a performance criterion under the program, was set aside in the past year given concerns over constitutionality and risks that such legislation would be weakened in the current political environment. Accordingly, the program sets as a performance criterion the development of a detailed road-map (MEFP $\$ 13$ ) on introducing an FRL, for consideration by the new government after the elections, including pre-conditions such as: (i) bringing extra-budgetary entities on-budget; (ii) setting spending ceilings early on in the budget process; and (iii) removing automatic transfers. The road-map will address whether these proposals will require amendments to the constitution and is to be prepared by a high-level group comprising representatives from the Ministry of Finance, Central Bank, and the Economic Commission of the National Assembly.

\section{A number of related reforms to strengthen the budgetary process and} framework have been passed in the context of the financial administration law (FAL). Pending additional steps towards an FRL, the authorities have moved ahead with the FAL as a prior action for the program. The law was passed in July 2005. As advised by Fund staff, the law provided for: (i) transfer to the ministry of finance of full control of the capital budget, greatly strengthening control over budget execution, and (ii) approval of all budgetary expenditures by the assembly (including any financed with concessional resources), thus increasing accountability. The law also requires sending budgets for all decentralized agencies to the assembly for information, though not for approval (deemed unconstitutional). However, the law also left the assembly free to increase spending if financing can be identified, and to change the composition of expenditures. Given constitutionality concerns, and pending a definitive resolution of this concern in the context of an FRL, the authorities further strengthened the FAL in November to set-up a consensusbuilding commission (with representation from the ministry of finance and the assembly), that will assess, inter alia, the realism of financing sources proposed by the assembly before the budget is approved.

${ }^{10}$ Chapter 3 of the Selected Issues Paper reviews the current monetary framework.

${ }^{11}$ An FRL would include fiscal rules for all levels of government, explicit transparency requirements to underpin the credibility of such rules, a comprehensive coverage of debt, and provide for an independent agency to monitor and enforce the framework. 
34. The authorities are trying to achieve effective decentralization. The program called for an incremental devolution of expenditure responsibilities equivalent to one-third of the government's revenue transfers to municipalities per annum, starting in 2005, such that by 2007 full fiscal neutrality would be achieved. However, devolution has been difficult, reflecting in part technical difficulties in matching devolved revenues and expenditures across municipalities as well as problems with the current legal framework. In this context, the President has issued a decree that aims to eliminate central government spending in areas that are considered the responsibility of municipalities, fulfilling a prior action for the program discussed in coordination with the World Bank (MEFP 111 ). In line with the decree, the 2006 budget cuts capital spending geared to municipalities by $1 / 2$ percent of GDP with respect to 2005 . These measures would devolve expenditures equivalent to more than $1 / 2$ of revenues transferred to municipalities in 2006.

\section{Achieving full decentralization will require revising the legal framework. In a}

first step, and another prior action for proceeding with the program, the assembly has passed a law delaying further increases in transfers to municipalities (they will now be increased from 7 to 10 percent of total revenues in 2010, not 2007). This will alleviate spending pressures when preparing the 2007 budget and allow time for further reform of the framework. The authorities noted that as part of the recent political accord, a broader agreement has been reached to change the laws underpinning the decentralization framework, to devolve clearly spending responsibilities to municipalities. As such, amendments to these laws would be submitted to the assembly by June 2006 (a benchmark in the MEFP, 110 ). In reforming the framework, it will be important to link explicitly the revenue transfers to municipalities embodied in the Municipal Transfers Law, with the devolution of spending responsibilities that should be more clearly defined in the Law on Municipalities. Moreover, effort will be required to resolve the technical difficulties in terms of matching revenues with decentralized expenditures. The mission stressed the importance of close collaboration with Fund and World Bank staff to ensure that the proposed reforms are in line with international best practices.

\section{The recently approved tax code has significant weaknesses that undermine the tax administration, raising risks for tax collection, and needs to be strengthened.} Introducing a tax code to strengthen tax administration, in line with international best practices, has been a key policy priority and was a program benchmark for October 2004. By contrast, the version of the tax code approved in October 2005 (and going into effect in April 2006) introduces significant weaknesses that need to be addressed urgently, including on the ability of the tax administration to collect information, conduct audits, as well as enforce its decisions. Moreover, the code includes an overly broad release of liability for tax payers who use authorized third parties (such as accountants) to prepare their returns and also gives the tax administration discretion to waive and reduce fines. These weaknesses risk undermining tax collection, even in the near term. The authorities indicated that they share these concerns and are in the process of preparing amendments to the law, which are being discussed with the private sector and political parties. Reflecting the authorities' request for more time to iron out remaining substantive issues on the amendments and build political consensus on the 
measure, the program includes passage of these amendments as an end-March 2006 performance criterion (MEFP \15).

\section{The authorities intend to prepare a reform strategy that puts the public pension} system on a sound financial footing, without relying on government subsidies. The pension system is actuarially insolvent, though its cash-flow position is not expected to deteriorate sharply over the next decade or so. A previous reform aimed at transiting to a funded pension system, but this plan was dropped when a re-assessment indicated that the transition costs would be prohibitively high. Following this, the assembly approved a social security law, subsequently vetoed by the President that essentially increased benefits without raising contributions in addition to weakening the system's governance structure. In the event, implementation of this law has been deferred until after the election as a prior action for the program, and next steps will be considered by the new government. Accordingly, the authorities have indicated their commitment, as a performance criterion (MEFP 914 ), to prepare a specific recommendation for reform of the system. The plan would build on the work of the previous presidential commission that examined options in this area, and be prepared by mid-2006. However, implementation will be left for the new government to avoid any possible dilution in an electoral environment.

\section{Other structural reforms}

38. Reforming the recently approved Energy Stability Law (ESL) will be crucial for attracting needed new investment into the sector. The authorities noted that ESL was approved quickly during a period of crisis in the sector (power blackouts were ongoing when the law was passed). While the law introduces an important change in allowing for monthly adjustments in tariffs (previously these could be changed only annually), and tougher actions against power theft, it also introduces distortionary interventions. In particular, it caps electricity spot market prices as defined mark-up's over long-run contract prices, disrupting the price signal in the market and reducing incentives for peak-power producers to enter into the market. Further, the law includes provisions for potentially capping retail gasoline prices and levying a fine on excess profits by distributors, which would be used to provide subsidies and set up a "transport fund." The authorities note there are failures in these markets, but agreed that they could be addressed through regulation as opposed to in the law. Accordingly, the program includes an August 2006 structural performance criterion (MEFP \16) on approval of legislation by the assembly eliminating these distortionary elements of the ESL, allowing time for consultation, including with the IADB and the World Bank, on how to proceed with further reforms.

\section{Significant strides have been made with advancing financial sector reforms in} line with key FSAP recommendations. As prior actions for the program, the authorities have successfully sought passage of, and subsequent amendments to, three crucial financial sector laws. These laws embody core FSAP recommendations such as incorporating predetermined triggers for the application of corrective measures when a bank's capital ratio falls below a certain level. Further, the independence of the bank superintendency has been strengthened by removing all politically connected persons from its Board of Directors 
(including the Minister of Finance). Moreover, the superintendency law has clarified that any judicial action against the assets of intervened banks should be stayed until the intervention process is completed. The approved Deposit Insurance Law (FOGADE) codifies the role and procedures for FOGADE including in the context of bank intervention. Also, regulations for consolidated supervision have been issued which strengthen the "ring-fencing" of operations of local banks involved in cross border activities. The staff welcomed these developments but cautioned that developing the implementing rules and regulations of the recently approved laws will be crucial to ensure their effectiveness and that further strengthening of the legal framework will be needed following successful initial implementation of the laws.

\section{However, some important FSAP recommendations will remain on the reform}

agenda. The Nicaraguan authorities, as is the case with many others in the region, have not been able to substantially strengthen legal protections for supervisors. Moreover, it will be important to increase the role of the superintendency in the surveillance of major acquisitions of financial institutions, and strengthen further regulations on "fit and proper" tests. Other recommendations on recapitalizing the central bank, strengthening the framework for monetary operations and on judicial reform have yet to progress. In this regard, the authorities have agreed to prepare an action plan, for consideration by the next government, on the next steps for implementing FSAP recommendations (MEFP 918 ). Nicaragua's AML/CFT framework was assessed in September 2004 and several weaknesses identified including with regards to criminalization of activities as well as a weak regulatory framework for the financial sector. The latter concern has been eased somewhat in principle, reflecting the revamped regulatory framework. However, additional steps are needed including action to pass the Anti-Drug law and the Anti-Terrorism Law.

\section{PRogram MOdALITIES AND RiskS}

41. It is proposed to maintain the level of access unchanged under the PRGF arrangement and rephase remaining purchases over the extended program.

The authorities inquired about the possibility of an augmentation of access in light of the oil shock. However, a detailed assessment of the associated balance of payments impact and financing outlook showed that these were manageable within existing program parameters.
Nicaragua: Proposed Phasing of Disbursements Under the Extended PRGF Arrangement (In millions of SDR)

\begin{tabular}{lccc}
\hline Reviews & Test date & $\begin{array}{c}\text { Disbursement } \\
\text { date }\end{array}$ & Amount \\
\hline \multicolumn{2}{l}{ Amount disbursed to date: } & & 55.72 \\
7th, 8th, \& & end-Jun. 04 & Jan. 06 & 13.93 \\
9th & end-Sep. 04 & & \\
& end-Dec. 04 & & \\
10th & end-Mar 06 & Jun. 06 & 13.93 \\
11th & end-Jun 06 & Sep. 06 & 13.92 \\
Total & & & 97.50 \\
\hline
\end{tabular}

\section{The main risk for the program continues to be the difficult political situation.}

While political tensions have eased recently, allowing for support of the core program elements, Nicaraguan politics has historically been marked by sudden reversals. This remains a central risk, especially going into an election year, and is a key factor driving the heavy reliance on prior actions. Other risks include a possible deterioration of fiscal performance, including from an inability to further raise power rates, from further wage increases, and 
from a deterioration in tax administration if the new tax code is not amended, as well as the continued fragilities implied by the highly dollarized financial system.

43. Program monitoring. Prior actions for the seventh, eighth and ninth reviews are summarized in Attachment II, Table 1. These have all been completed. Quarterly reviews are proposed for the remainder of the arrangement to contain further downside risks to the Fund, to be carried out by June and September 2006, based on the observance of the relevant quantitative and structural performance criteria. Quantitative targets are being proposed as PCs for end-March and end-June 2006. Reflecting the concerns over rapid wage growth and high losses in the power sector, two new PCs are proposed on the public sector wage bill and average electricity tariffs. New structural PCs are being proposed on the passage of a revised tax code (end-March), amendments to the ESL (end-August), preparation of roadmaps for the FRL (end-August) and pension reform (end-June) and benchmarks are being added on decentralization, plans for further financial sector reform, and strengthening fiscal accounting (Attachment II, Table 1).

\section{FINANCING ASSURANCES}

44. The program is fully financed for 2006. Multilateral and bilateral donors are expected to provide substantial BOP and budget support to Nicaragua in 2005-06 in the context of the Fund-supported arrangement.

Nicaragua: Program Financing, 2005-06

(Period flows, in millions of US dollars)

\begin{tabular}{|c|c|c|c|c|c|c|}
\hline & \multirow[t]{2}{*}{2005} & \multicolumn{5}{|c|}{2006} \\
\hline & & Q1 & Q2 & Q3 & Q4 & Total \\
\hline Total & 429.0 & 170.1 & 121.4 & 134.6 & 177.8 & 603.8 \\
\hline Grants & 190.3 & 44.0 & 50.7 & 59.1 & 47.8 & 201.6 \\
\hline Untied & 35.3 & 17.7 & 17.8 & 25.1 & 3.2 & 63.8 \\
\hline Of which: central government & 35.3 & 17.7 & 17.8 & 25.1 & 3.2 & 63.8 \\
\hline Tied & 155.0 & 26.3 & 32.9 & 34.0 & 44.6 & 137.8 \\
\hline Of which: central government & 143.4 & 23.6 & 29.5 & 30.5 & 37.1 & 120.7 \\
\hline Loans & 238.7 & 126.1 & 69.6 & 75.5 & 120.0 & 391.1 \\
\hline Untied & 0.0 & 85.3 & 10.0 & 20.3 & 44.1 & 159.6 \\
\hline IMF disbursments & 0.0 & 20.3 & 0.0 & 20.3 & 20.3 & 60.8 \\
\hline Other untied loans & 0.0 & 65.0 & 10.0 & 0.0 & 23.8 & 98.8 \\
\hline IDA & 0.0 & 35.0 & 0.0 & 0.0 & 20.0 & 55.0 \\
\hline Others multilaterals & 0.0 & 30.0 & 10.0 & 0.0 & 0.0 & 40.0 \\
\hline Paris Club & 0.0 & 0.0 & 0.0 & 0.0 & 3.8 & 3.8 \\
\hline Of which: central government & 0.0 & 65.0 & 10.0 & 0.0 & 23.8 & 98.8 \\
\hline Tied & 238.7 & 40.8 & 59.6 & 55.2 & 75.9 & 231.5 \\
\hline Of which: central government & 208.6 & 34.6 & 51.0 & 48.2 & 57.9 & 191.7 \\
\hline Privatization & 0.0 & 0.0 & 1.1 & 0.0 & 10.0 & 11.1 \\
\hline
\end{tabular}

Source: Central Bank of Nicaragua and staff's estimates. 
45. The authorities are making good faith efforts to resolve outstanding official and private debt issues, and some progress is being achieved. The authorities are continuing negotiations to obtain debt relief from non-Paris Club creditors, but progress has been slow as a number of creditors are unwilling to provide relief on Paris-Club comparable terms. Separately, the authorities have retained advisors as they seek to reach agreement with remaining commercial creditors in the context of the preparation of a World Bank-financed buy-back operation of commercial debt.

\section{The Executive Board has determined that Nicaragua meets the qualification} criteria for receiving debt relief under the MDRI. The Fund is prepared to approve MDRI relief for Nicaragua as soon as the remaining consents of the contributors to the PRGF Trust Subsidy Account have been received. The authorities are committed to use resources that could be freed up by the MDRI to increase poverty-reducing spending. Under current assumptions (implementation with effect from January 2006 for the Fund and July 2006 for the Bank) the savings in 2006 would be around US\$15 million (0.3 percent of GDP), backloaded in the second half of the year. Corresponding adjustors have been added to the program quantitative targets (TMU $\mid \mathrm{s} 20-24$ ). These adjustors will be revisited at the time of the next review, once the modalities and timing of the debt relief have been further clarified.

\section{OTHER ISSUES}

47. Nicaragua has taken significant steps to strengthen its economic statistics in recent years, but important weaknesses remain to be addressed. A recent ROSC data module found that while the existing legal framework is sufficient to provide the authority for the collection and compilation of statistics, there is a need to strengthen its capacity to obtain information from the private and public sector. Additionally, there is a need for further improvements in the methodological basis and source data, as well as in the release of advance publication calendars.

\section{StafF APPRAISAL}

48. The authorities have taken significant steps to reforge the domestic consensus for the reform agenda supported under the PRGF arrangement. After a period when structural reforms were halted, the recent political accord has fostered a productive legislative session in support of key measures envisaged under the program. This reflects the strong domestic support for the benefits engendered by the program, in terms of stability and poverty reduction.

49. The authorities have also been able to maintain a broadly stable macroeconomic framework. The economy has continued to grow and several poverty related indicators have improved. Meanwhile, the fiscal consolidation process has advanced and debt levels have fallen. However, inflation has picked up, reflecting in part the impact of higher oil prices.

50. The authorities' medium-term strategy seeks to enhance growth, promote stability and support achievement of the MDGs. Its prospects hinge on measures to boost 
investment and productivity while increasing anti-poverty spending and reducing large existing macro imbalances. This will require continued fiscal consolidation and reforms to strengthen the investment climate and regulatory framework to take full advantage of the opportunities offered by CAFTA-DR. Nicaragua's external competitiveness has improved in recent years, but containing wage pressures will be crucial going forward. The traded sector has expanded rapidly but debt-creating external financing remains sizeable and further reductions in the current account deficit will be crucial for assuring external sustainability.

\section{The fiscal strategy should focus on reducing debt levels while creating room for} poverty-reducing spending. With gradually paced fiscal consolidation adjustment made possible by the continued availability of high levels of grants and other concessional finance, debt levels would eventually start to decline and debt service levels remain manageable. It will be important to reduce the numerous rigidities - including earmarking of spending - that currently compress budget resources available for poverty-reducing spending. A first step would be raising public awareness by discussing the impact of these rigidities in the context of strengthening the fiscal responsibility framework (MEFP 99 ).

52. The fiscal policy stance embodied in the $\mathbf{2 0 0 6}$ budget will support stability in the run up to the elections later in the year. The budget implies tight control over primary nonpoverty reducing spending consistent with achieving the authorities' target of an unchanged fiscal balance in 2006. To cover risks and create space for poverty-reducing spending, it will be important to identify lower priority expenditures that could be cut, if necessary, to meet the fiscal target, as well as to consider phasing out tax exemptions and lowering deductions to mobilize additional resources.

53. Losses in the electricity sector need to be tackled urgently. Further rate increases should be implemented as soon as possible - while protecting the poor through continuing the subsidy to low-usage consumers - and a mechanism for automatic adjustment of tariffs with fluctuations in fuel costs should be put in place to prevent losses from occurring again in the future. It is also important to reform the ESL and eliminate distortionary interventions in the energy market, which could deter critically needed investment.

54. It will be crucial to contain public sector wage growth to no more than expected inflation. Given the large size of the public sector wage bill, and rapid increases of public sector average wages in recent years, it is hard to justify significant further increases in public sector wages at this time. Rapid wage bill growth raises risks for competitiveness, fiscal sustainability and poverty spending. The budget appropriately builds in wage restraint, but this will likely remain a key pressure point for the program in the 2006 election year.

\section{Action envisaged under the program by the central bank to tighten liquidity} conditions will help safeguard reserves and maintain stability. The supportive fiscal policy stance will facilitate the central banks efforts to tighten liquidity conditions to curb rapid real credit growth and maintain credibility before the elections. This will also help contain rising inflation that could reflect second-round effects of the oil shock and demand pressures including from the impact of the public wage hikes and high credit growth. 
Keeping unchanged the rate of crawl of the exchange rate peg in 2006 will appropriately balance stability and competitiveness. It will be important to consider moving to a more flexible exchange regime over the medium term.

\section{Early action to strengthen the tax code is crucial to safeguard the fiscal}

framework. Reforms to strengthen the tax administration have proven controversial in Nicaragua, reflecting in part opposition from strong vested interests as well as concerns over the possible use of the tax administration for political purposes. As such, the authorities' desire to build a broad consensus for the measure is understandable. However, the code approved significantly weakens the authority of the tax administration and raises risks that collection could fall even in the near term. It is critical that the law be strengthened early on, as envisaged under the program.

\section{It will be important to set the stage in the year ahead for advancing with} structural reforms to strengthen the fiscal framework at an early stage after the elections. Steps have been taken as prior actions to safeguard the fiscal framework, including approval of the FAL and deferral of the weak social security law. However, further actions are required. The program recognizes the political realities and risks involved with tackling difficult fiscal reforms in an election year. As such, key elements of the program in the year ahead will include developing a plan, to be implemented by the next administration, for introducing a credible FRL and for reforming the insolvent pension system. Moreover, the flawed decentralization process also needs to be addressed. Steps taken as prior actions under the program will mitigate fiscal pressures arising from the decentralization process.

However, a fundamental solution will require changing the laws underpinning the framework in tandem with capacity building at the municipal level over the medium term. The program benchmark on reforming the decentralization laws could constitute an important first step on this likely long journey.

58. The authorities have made commendable progress with strengthening the financial sector framework. The key laws passed this year embody many core FSAP recommendations. However, further work is needed to ensure smooth implementation of these laws and completing other FSAP recommendations. The program extension provides a valuable opportunity to take stock of the situation and policy requirements going forward following election of a new government in 2006.

\section{The staff recommends approval of the authorities' request for a waiver of} nonobservance of performance criteria, completion of the seventh, eighth and ninth reviews, rephasing of purchases, financing assurances review and an extension of the PRGF arrangement through December 12, 2006. This reflects the overall satisfactory macro-performance, the authorities' renewed commitment to the program, as evidenced by the completion of a whole set of prior actions, as well as the introduction of new quantitative PCs in areas that exhibited weaknesses in 2005 (wages and electricity tariffs). Satisfactory assurances of external financing are evidenced by recent pledges of budget support by donors, and the authorities' intent to use the IDA Debt Reduction Facility to resolve the commercial debt problem. Thus, the staff recommends completion of the financing 
assurances review. The staff supports the authorities' request for a waiver of the performance criterion on the central government balance after grants as the deviation was minor and the authorities are taking the necessary measures to keep the fiscal program on track. Staff also supports the authorities' request for a waiver of the structural PC on passing an FRL in light of the authorities' corrective actions, evidenced by the passage of the FAL and commitment to develop a plan for introducing an FRL. An extension of the program should help support the authorities' macro-economic framework in the run-up to next year's elections. It will be crucial to continue to build public support and ownership for the key program elements in the run-up to the elections to help shape the national dialogue.

60. It is expected that the next Article IV consultation with Nicaragua will be held on a standard 24-month cycle. 
Table 1. Nicaragua: Selected Economic Indicators

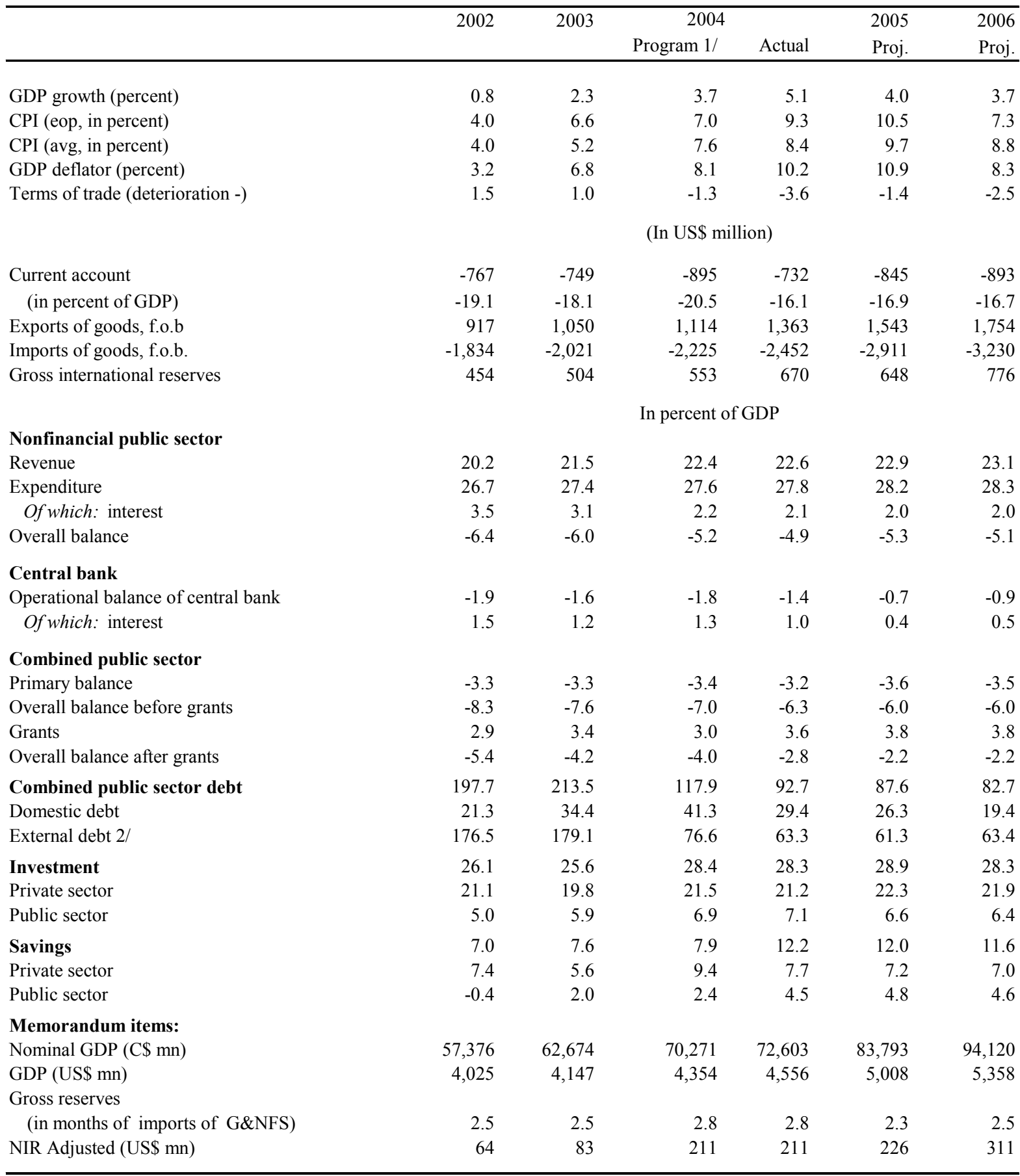

Sources: Central Bank of Nicaragua; Ministry of Finance; and Fund staff estimates/projections.

1/ As stated in Country Report No. 04/347

2/ After HIPC relief, assuming that negotiations with non-Paris Club and commercial creditors are completed by end-2005. Includes accrued interests on private debt in arrears. 
Table 2. Nicaragua: Operations of the Central Government (in percent of GDP)

\begin{tabular}{|c|c|c|c|c|c|c|}
\hline & \multirow[t]{2}{*}{2002} & \multirow[t]{2}{*}{2003} & \multicolumn{2}{|c|}{2004} & \multirow{2}{*}{$\begin{array}{r}2005 \\
\text { Proj. }\end{array}$} & \multirow{2}{*}{$\begin{array}{r}2006 \\
\text { Proj. }\end{array}$} \\
\hline & & & Program 1/ & Actual & & \\
\hline Total revenue & 15.0 & 16.2 & 16.8 & 16.9 & 17.6 & 17.6 \\
\hline Tax & 13.5 & 15.0 & 15.5 & 15.5 & 16.4 & 16.3 \\
\hline Nontax and current transfers & 1.5 & 1.2 & 1.2 & 1.4 & 1.2 & 1.3 \\
\hline Total expenditures & 21.4 & 22.3 & 21.6 & 22.3 & 22.9 & 22.7 \\
\hline Wages and salaries 2/ & 4.4 & 4.5 & 4.2 & 4.0 & 4.0 & 4.2 \\
\hline Goods and services & 2.4 & 2.1 & 2.0 & 2.1 & 2.1 & 2.6 \\
\hline Interest 3/ & 3.5 & 3.1 & 2.1 & 2.0 & 2.0 & 1.9 \\
\hline Current transfers & 4.3 & 4.2 & 4.3 & 4.6 & 5.2 & 5.8 \\
\hline Of which: Municipalities & 0.1 & 0.0 & 0.2 & 0.2 & 0.3 & 0.3 \\
\hline Capital expenditures & 4.3 & 5.5 & 5.9 & 5.9 & 5.6 & 4.8 \\
\hline Capital transfers & 2.6 & 3.0 & 3.0 & 3.7 & 4.1 & 3.4 \\
\hline Of which: Municipalities & 0.2 & 0.2 & 0.4 & 0.4 & 0.7 & 0.7 \\
\hline Overall balance (before grants) & -6.4 & -6.1 & -4.8 & -5.4 & -5.3 & -5.1 \\
\hline Primary balance (before grants) & -2.9 & -3.0 & -2.7 & -3.4 & -3.4 & -3.2 \\
\hline Grants & 2.5 & 2.9 & 2.7 & 3.3 & 3.6 & 3.5 \\
\hline Overall balance (after grants) & -3.9 & -3.2 & -2.1 & -2.2 & -1.7 & -1.7 \\
\hline Net financing & 3.9 & 3.2 & 2.1 & 2.2 & 1.7 & 1.7 \\
\hline External & 3.7 & 5.4 & 5.9 & 5.6 & 3.3 & 4.7 \\
\hline Amortization 3/ & -4.6 & -4.4 & -0.5 & -0.5 & -0.6 & -0.8 \\
\hline Disbursements & 4.3 & 5.9 & 6.4 & 6.1 & 4.0 & 5.4 \\
\hline Change in arrears & 4.0 & 3.9 & 0.0 & 0.0 & 0.0 & 0.0 \\
\hline Domestic & -0.2 & -2.5 & -5.2 & -4.9 & -1.8 & -3.2 \\
\hline Central bank & -2.4 & -1.6 & -4.2 & -4.4 & -0.9 & -2.1 \\
\hline Rest of financial system & 0.6 & 0.1 & -0.3 & -0.1 & -0.1 & -0.1 \\
\hline Other & 1.7 & -1.0 & -0.7 & -0.3 & -0.7 & -1.0 \\
\hline Privatization & 0.4 & 0.3 & 1.4 & 1.4 & 0.2 & 0.2 \\
\hline \multicolumn{7}{|l|}{ Memorandum item: } \\
\hline Total effective monitorable wage bill 4/ & $\ldots$ & $\ldots$. & $\ldots$ & $\ldots$ & 6.9 & 6.7 \\
\hline Total poverty related expenditures $5 / 6$ / & $\ldots$ & 10.9 & $\ldots$ & 12.3 & 12.5 & 12.4 \\
\hline Nominal GDP (millions of Cordobas) & 57,376 & 62,674 & 70,271 & 72,603 & 83,793 & 94,120 \\
\hline
\end{tabular}

Sources: Ministry of Finance of Nicaragua; Central Bank of Nicaragua; and Fund staff estimates/projections.

$1 /$ As stated in Country Report No. 04/347

2/ Total employee compensation is not entirely reflected in wages and salaries. Some employees obtain part of their salary through current transfers. In 2006, this figure includes salaries for temporary workers related to general elections of 0.2 percent of GDP.

3/ Measured on an accrual basis for 2002 and 2003

4/ Wages and salaries plus social security contributions and other benefits in personal services; plus current . transfers to autonomous educational institutions.

5/ Projected numbers from SECEP.

6/ Change in methodology starting in 2004 
Table 3. Nicaragua: Operations of the Combined Public Sector

\begin{tabular}{|c|c|c|c|c|c|c|}
\hline & \multirow[t]{2}{*}{2002} & \multirow[t]{2}{*}{2003} & \multicolumn{2}{|l|}{2004} & \multirow{2}{*}{$\begin{array}{c}2005 \\
\text { Proj. }\end{array}$} & \multirow{2}{*}{$\begin{array}{r}2006 \\
\text { Proj. }\end{array}$} \\
\hline & & & Program 1/ & Actual & & \\
\hline \multicolumn{7}{|l|}{ General government 2 / } \\
\hline Revenue & 20.0 & 21.4 & 22.0 & 22.3 & 22.8 & 22.8 \\
\hline Expenditure & 25.6 & 26.7 & 25.9 & 26.6 & 27.0 & 26.8 \\
\hline Noninterest & 22.0 & 23.6 & 23.8 & 24.5 & 25.0 & 24.9 \\
\hline Current & 15.0 & 14.8 & 14.6 & 14.7 & 15.2 & 16.4 \\
\hline Capital and net lending & 7.0 & 8.9 & 9.2 & 9.8 & 9.9 & 8.5 \\
\hline Interest 3/ & 3.5 & 3.1 & 2.1 & 2.0 & 2.0 & 1.9 \\
\hline Overall balance (before grants) & -5.6 & -5.3 & -4.0 & -4.3 & -4.3 & -4.1 \\
\hline Primary balance & -2.0 & -2.2 & -1.8 & -2.2 & -2.3 & -2.1 \\
\hline Overall balance of public enterprises (before grants) 4/ & -0.8 & -0.7 & -1.3 & -0.7 & -1.0 & -1.1 \\
\hline Current operating surplus of PE & 0.2 & 0.0 & 0.3 & 0.3 & 0.2 & 0.3 \\
\hline Fixed capital formation & -1.1 & -0.7 & -1.6 & -1.2 & -1.2 & -1.5 \\
\hline Interests & 0.0 & 0.0 & & 0.0 & -0.1 & 0.0 \\
\hline BCN operating balance & -1.9 & -1.6 & -1.8 & -1.4 & -0.7 & -0.9 \\
\hline Of which: Interest Payments & 1.5 & 1.2 & 1.3 & 1.0 & 0.4 & 0.5 \\
\hline Primary balance CPS (before grants) & -3.3 & -3.3 & -3.4 & -3.2 & -3.6 & -3.5 \\
\hline Overall balance CPS (before grants) & -8.3 & -7.6 & -7.0 & -6.3 & -6.0 & -6.0 \\
\hline Grants & 2.9 & 3.4 & 3.0 & 3.6 & 3.8 & 3.8 \\
\hline Overall balance CPS (after grants) & -5.4 & -4.2 & -4.0 & -2.8 & -2.2 & -2.2 \\
\hline Net Financing & 5.4 & 4.2 & 4.0 & 2.8 & 2.2 & 2.2 \\
\hline External & 4.2 & 5.6 & 6.6 & 6.0 & 3.7 & 5.4 \\
\hline Amortization 4/ & -4.6 & -4.4 & -0.5 & -0.5 & -0.6 & -0.8 \\
\hline Disbursements & 4.8 & 6.1 & 7.0 & 6.5 & 4.4 & 6.2 \\
\hline Change in Arrears & 4.0 & 3.9 & 0.0 & 0.0 & 0.0 & 0.0 \\
\hline Domestic & 0.8 & -1.7 & -4.0 & -4.7 & -1.8 & -3.4 \\
\hline Central bank & -2.6 & -2.2 & -4.5 & -4.8 & -1.1 & -2.1 \\
\hline Rest of financial system & -0.3 & -0.8 & -0.7 & -0.8 & -0.7 & -1.2 \\
\hline Other & 3.6 & 1.3 & 1.2 & 0.9 & 0.1 & -0.1 \\
\hline Privatization & 0.4 & 0.3 & 1.4 & 1.4 & 0.2 & 0.2 \\
\hline \multicolumn{7}{|l|}{ Memorandum items: } \\
\hline Total poverty related expenditures $5 / 6$ / & 10.2 & 11.4 & 11.4 & 13.2 & 13.4 & 13.5 \\
\hline Election expenditure & $\ldots$ & $\ldots$ & $\ldots$ & $\ldots$ & $\ldots$ & 0.9 \\
\hline Electricity subsidy $7 /$ & $\ldots$ & $\ldots$ & $\ldots$ & $\ldots$ & 0.6 & $\ldots$ \\
\hline Nominal GDP (millions of Cordobas) & 57,376 & 62,674 & 70,271 & 72,603 & 83,793 & 94,120 \\
\hline
\end{tabular}

Sources: Ministry of Finance of Nicaragua; Central Bank of Nicaragua; and Fund staff estimates/projections.

1/ As stated in Country Report No. 04/347

2/ Includes central government (CG), the municipality of Managua (ALMA) and the social security institute (INSS).

3/ For 2002 and 2003, includes domestic interest payments on accrual basis.

4/ For 2004-2006, consolidated public sector includes additional public enterprises: ENEL, TELCOR, and ENAP.

5 / Projected numbers from SECEP.

6/ Change in methodology starting in 2004

7/ Includes forgiveness of arrears from ENEL to UF of U\$18.6 mill. plus U\$17.6 mill. (U\$12 mill. of government subsidy

and U\$5.6 mill. of ENEL profits transferred to UF) to cover losses in electricity sector. 
Table 4: Operations of the Central Government (in millions of Cordobas)

\begin{tabular}{|c|c|c|c|c|c|c|c|c|c|c|}
\hline & \multicolumn{4}{|c|}{2005} & \multicolumn{6}{|c|}{2006} \\
\hline & Q1 & Q2 & Q3 & Q4 & & Q1 & Q2 & Q3 & Q4 & \\
\hline & & & & & Total & Proj. & Proj. & Proj. & Proj. & Total \\
\hline Total revenue & 3,556 & 3,542 & 3,810 & 3,816 & 14,723 & 3,964 & 4,046 & 4,350 & 4,210 & 16,570 \\
\hline Tax & 3,323 & 3,274 & 3,530 & 3,621 & 13,749 & 3,596 & 3,722 & 4,092 & 3,945 & 15,355 \\
\hline Nontax and current transfers & 233 & 268 & 279 & 195 & 974 & 368 & 324 & 258 & 265 & 1,215 \\
\hline Total expenditures & 3,811 & 4,633 & 4,263 & 6,465 & 19,172 & 4,778 & 5,177 & 5,465 & 5,958 & 21,378 \\
\hline Wages and salaries /1 & 675 & 834 & 804 & 1,056 & 3,369 & 898 & 919 & 931 & 1,228 & 3,975 \\
\hline Goods and services & 385 & 404 & 435 & 528 & 1,752 & 465 & 604 & 709 & 627 & 2,405 \\
\hline Interest & 430 & 278 & 460 & 474 & 1,642 & 550 & 310 & 548 & 398 & 1,806 \\
\hline Current transfers & 976 & 1,052 & 971 & 1,318 & 4,317 & 1,332 & 1,345 & 1,289 & 1,454 & 5,420 \\
\hline of which: Municipalities & 51 & 51 & 57 & 77 & 236 & 66 & 66 & 66 & 66 & 263 \\
\hline Capital expenditures and net lending & 723 & 1,279 & 865 & 1,808 & 4,674 & 777 & 1,186 & 1,081 & 1,482 & 4,527 \\
\hline Capital transfers & 622 & 786 & 728 & 1,282 & 3,418 & 757 & 814 & 907 & 768 & 3,245 \\
\hline of which: Municipalities & 165 & 64 & 207 & 134 & 570 & 215 & 262 & 215 & 0 & 692 \\
\hline Overall balance (before grants) & -256 & $-1,091$ & -454 & $-2,649$ & $-4,449$ & -813 & $-1,132$ & $-1,115$ & $-1,748$ & $-4,808$ \\
\hline Primary balance (before grants) & 174 & -813 & 7 & $-2,175$ & $-2,807$ & -264 & -821 & -568 & $-1,349$ & $-3,002$ \\
\hline Grants & 249 & 662 & 374 & 1,699 & 2,984 & 728 & 832 & 978 & 710 & 3,248 \\
\hline Overall balance (after grants) & -7 & -429 & -79 & -950 & $-1,465$ & -86 & -300 & -137 & $-1,037$ & $-1,560$ \\
\hline Net Financing & 7 & 429 & 79 & 950 & 1,465 & 86 & 300 & 137 & 1,037 & 1,560 \\
\hline External & 996 & 802 & 729 & 249 & 2,776 & 1,610 & 953 & 624 & 1,196 & 4,384 \\
\hline Amortization & -98 & -95 & -180 & -166 & -540 & -143 & -122 & -224 & -241 & -729 \\
\hline Disbursements & 1,094 & 897 & 909 & 415 & 3,316 & 1,753 & 1,074 & 848 & 1,437 & 5,113 \\
\hline Change in Arrears & 0 & 0 & 0 & 0 & 0 & 0 & 0 & 0 & 0 & 0 \\
\hline Domestic & -989 & -374 & -650 & 518 & $-1,496$ & $-1,525$ & -672 & -487 & -335 & $-3,018$ \\
\hline Central bank & -116 & -383 & -494 & 198 & -795 & -528 & -769 & -412 & -275 & $-1,984$ \\
\hline Rest of financial system & -58 & -7 & -46 & 10 & -102 & -17 & 0 & 0 & -90 & -107 \\
\hline Other & -815 & 16 & -110 & 310 & -599 & -980 & 98 & -75 & 31 & -927 \\
\hline Privatization & 0 & 1 & 0 & 184 & 185 & 0 & 19 & 0 & 176 & 195 \\
\hline \multicolumn{11}{|l|}{ Memorandum item } \\
\hline Nominal GDP (millions of Cordobas) & 83,793 & 83,793 & 83,793 & 83,793 & 83,793 & 94120 & 94120 & 94120 & 94120 & 94120 \\
\hline Transfers to municipalities & 215.6 & 115.0 & 201.4 & 273.6 & 805.5 & 280.7 & 328.1 & 280.7 & 65.7 & 955.2 \\
\hline
\end{tabular}

1/ Total employee compensation is not entirely reflected in wages and salaries. Some employees obtain part of their salary through current transfers. In 2006, this figure includes salaries for temporary workers related to general elections of 0.2 percent of GDP. 
Table 5: Operations of the Combined Public Sector

(in millions of Cordobas)

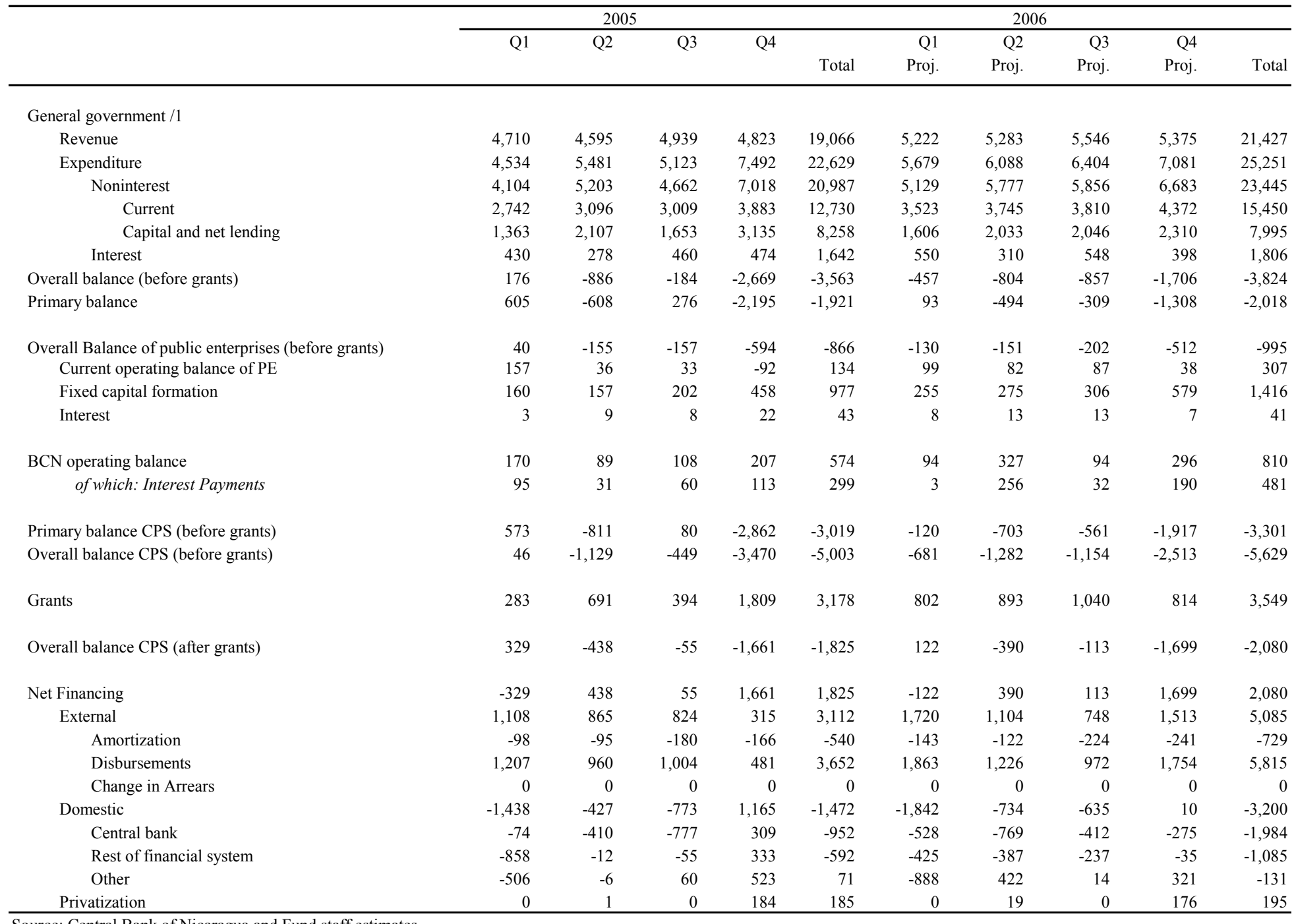

Source: Central Bank of Nicaragua and Fund staff estimates.

1/ Includes central government (CG), the municipality of Managua (ALMA) and the social security institute (INSS) 
Table 6. Nicaragua: Summary Accounts of the Central Bank

(Flows in millions of cordobas; unless otherwise stated)

\begin{tabular}{|c|c|c|c|c|c|c|}
\hline & \multirow[b]{2}{*}{2002} & \multirow[b]{2}{*}{2003} & \multicolumn{2}{|c|}{2004} & \multicolumn{2}{|c|}{ Projected } \\
\hline & & & Program 1/ & Actual & 2005 & 2006 \\
\hline Exchange rate (cordobas/US\$) & 14.3 & 15.1 & 15.9 & 15.9 & 16.7 & $\ldots$ \\
\hline Net international reserves (adjusted) 2/ & 692 & 277 & 318 & 2,043 & 250 & 1,496 \\
\hline (In millions of US\$) & 49 & 18 & 20 & 128 & 15 & 85 \\
\hline Net domestic assets & -555 & 144 & -91 & $-1,446$ & 290 & -974 \\
\hline Net credit to Public sector (NFPS) & $-1,329$ & $-1,682$ & $-3,455$ & $-3,569$ & -953 & $-1,984$ \\
\hline Deposits & $-1,209$ & $-1,378$ & $\ldots$ & $-2,568$ & -221 & $-1,120$ \\
\hline Net credit to the financial system & -696 & -600 & 22 & -457 & -354 & -387 \\
\hline Operational losses & 1,115 & 1,006 & 1,490 & 1,031 & 574 & 810 \\
\hline Central banks bonds 3 / & 407 & 1,719 & 1,358 & 1,501 & 951 & 579 \\
\hline Amortization banking bonds & 563 & 779 & $\ldots$ & 893 & 572 & 600 \\
\hline Net open market operations & -156 & 940 & $\ldots$ & 607 & 380 & -21 \\
\hline Medium- and long-term foreign liabilities & 143 & 237 & 427 & 165 & 164 & 213 \\
\hline Other & -194 & -536 & 68 & -117 & -92 & -206 \\
\hline Currency & 136 & 421 & 227 & 597 & 540 & 522 \\
\hline \multicolumn{7}{|l|}{ Memorandum items: } \\
\hline Currency (stock) & 2,086 & 2,506 & 2,734 & 3,103 & 3,643 & 4,165 \\
\hline Currency (annual change; in percent) & 7.0 & 20.2 & 9.1 & 23.8 & 17.4 & 14.3 \\
\hline Change in external assets & 86 & 69 & $\ldots$ & 166 & -22 & 128 \\
\hline \multicolumn{7}{|l|}{ Strengthening of $\mathrm{BCN}$ reserve position } \\
\hline (In millions of US\$) & 82 & 89 & 97 & 201 & 62 & 118 \\
\hline Net repayment of BCN domestic debt $(+)$ & 33 & 71 & 77 & 73 & 47 & 33 \\
\hline Increase in Adjusted NIR $(+)$ & 49 & 18 & 20 & 128 & 15 & 85 \\
\hline
\end{tabular}

Sources: Central Bank of Nicaragua; and Fund staff estimates/projections.

$1 /$ As stated in Country Report No. 04/347

$2 /$ Net international reserves less reserve requirements in foreign currency.

3/ Letras, Bonos en Moneda Extranjera (BOMEX), and Titulos Especiales de Liquidez (TEL's). 
Table 7. Nicaragua: Summary Accounts of the Central Bank-Quarterly

(Flows in millions of cordobas; unless otherwise stated)

\begin{tabular}{|c|c|c|c|c|c|c|c|c|c|c|}
\hline & \multicolumn{4}{|c|}{2005} & \multirow[t]{2}{*}{2005} & \multicolumn{4}{|c|}{2006} & \multirow[t]{2}{*}{2006} \\
\hline & $1 \mathrm{Q}$ & $2 \mathrm{Q}$ & $3 \mathrm{Q}$ & $4 \mathrm{QQ}$ & & $1 \mathrm{Q}$ & $2 \mathrm{Q}$ & $3 \mathrm{Q}$ & $4 \mathrm{Q}$ & \\
\hline Exchange rate (cordobas/US\$) & 16.7 & 16.7 & 16.7 & 16.7 & 16.7 & 17.6 & 17.6 & 17.6 & 17.6 & 17.6 \\
\hline Net international reserves (adjusted) 1/ & -294 & -185 & 257 & 473 & 250 & 704 & 484 & 5 & 303 & 1,496 \\
\hline (In millions of US\$) & -18 & -11 & 15 & 28 & 15 & 40 & 28 & 0 & 17 & 85 \\
\hline Net domestic assets & 67 & 196 & -196 & 224 & 290 & -838 & -667 & -41 & 572 & -974 \\
\hline Net credit to Public sector (NFPS) & -87 & -400 & -682 & 216 & -953 & -528 & -769 & -412 & -275 & $-1,984$ \\
\hline Deposits & -87 & -38 & -682 & 585 & -221 & -433 & -385 & -412 & 110 & $-1,120$ \\
\hline Net credit to the financial system & -248 & -156 & 305 & -256 & -354 & -344 & -121 & 58 & 21 & -387 \\
\hline Operational losses & 170 & 89 & 108 & 207 & 574 & 94 & 327 & 94 & 296 & 810 \\
\hline Central banks bonds $2 /$ & 290 & 571 & 148 & -58 & 951 & 32 & -172 & 262 & 458 & 579 \\
\hline Amortization banking bonds & 0 & 282 & 0 & 289 & 572 & 0 & 300 & 0 & 300 & 600 \\
\hline Net open market operations & 290 & 289 & 148 & -348 & 380 & 32 & -472 & 262 & 158 & -21 \\
\hline Medium- and long-term foreign liabilities & 76 & 10 & 70 & 9 & 164 & 73 & 32 & 73 & 34 & 213 \\
\hline Other & -135 & 82 & -145 & 106 & -92 & -165 & 36 & -115 & 38 & -206 \\
\hline Currency & -227 & 10 & 61 & 697 & 540 & -135 & -182 & -36 & 874 & 522 \\
\hline \multicolumn{11}{|l|}{ Memorandum items: } \\
\hline Currency (stock) & 2,876 & 2,886 & 2,947 & 3,643 & 3,643 & 3,509 & 3,326 & 3,291 & 4,165 & 4,165 \\
\hline Currency (annual change; in percent) & 20.8 & 24.6 & 23.0 & 17.4 & 17.4 & 22.0 & 15.3 & 11.7 & 14.3 & 14.3 \\
\hline Change in external assets & -15.6 & -21.8 & -1.7 & 16.9 & -22.1 & 50.0 & 28.7 & 7.0 & 42.5 & 128.2 \\
\hline \multicolumn{11}{|l|}{ Strengthening of $\mathrm{BCN}$ reserve position } \\
\hline (In millions of US\$) & 1 & 22 & 13 & 26 & 62 & 42 & 18 & 15 & 43 & 118 \\
\hline Net repayment of BCN domestic debt $(+)$ & 19 & 33 & -2 & -2 & 47 & 2 & -10 & 15 & 26 & 33 \\
\hline Increase in Adjusted NIR (+) & -18 & -11 & 15 & 28 & 15 & 40 & 28 & 0 & 17 & 85 \\
\hline
\end{tabular}

Sources: Central Bank of Nicaragua; and Fund staff estimates/projections.

$1 /$ Net international reserves less reserve requirements in foreign currency.

2/ Letras, Bonos en Moneda Extranjera (BOMEX), and Titulos Especiales de Liquidez (TEL's). 
Table 8. Nicaragua: Summary Accounts of the Deposit Banks and Financial Sector (Flows in millions of cordobas; unless otherwise stated)

\begin{tabular}{|c|c|c|c|c|c|c|}
\hline & \multirow{2}{*}{2002} & \multirow{2}{*}{2003} & \multicolumn{2}{|c|}{2004} & \multirow{2}{*}{$\begin{array}{l}2005 \\
\text { Proj. } \\
\end{array}$} & \multirow{2}{*}{$\begin{array}{r}2006 \\
\text { Proj } \\
\end{array}$} \\
\hline & & & Program 1/ & Actual & & \\
\hline \multicolumn{7}{|c|}{ Commercial banks $2 /$} \\
\hline NIR adjusted & 503 & 335 & 270 & 326 & 52 & 106 \\
\hline Adjusted NIR in US\$ millions & 37 & 23 & 17 & 22 & 4 & 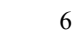 \\
\hline Net domestic assets & 850 & 1,293 & 1,803 & 2,258 & 2,827 & 1,482 \\
\hline Net credit to nonfinancial public sector & 480 & 697 & 1,055 & 1,155 & $-1,146$ & $-1,723$ \\
\hline Net credit to the financial system & 652 & 458 & 256 & 294 & 292 & 306 \\
\hline Net credit to the private sector & 807 & 2,245 & 2,967 & 3,134 & 4,000 & 3,167 \\
\hline Medium- and long-term foreign liabilities & -445 & 114 & -110 & -127 & -538 & -428 \\
\hline Other net assets & -645 & $-2,221$ & $-2,365$ & $-2,198$ & 219 & 161 \\
\hline Liabilities & 1,352 & 1,628 & 2,073 & 2,584 & 2,879 & 1,588 \\
\hline \multicolumn{7}{|c|}{ Financial Sector } \\
\hline NIR adjusted & 1,195 & 612 & 2,075 & 2,369 & 302 & 1,602 \\
\hline (In millions of US dollars) & 86 & 41 & 130 & 150 & 19 & 91 \\
\hline Net domestic assets & 294 & 1,437 & 859 & 812 & 3,117 & 508 \\
\hline Net credit to nonfinancial public sector & -849 & -985 & $-2,218$ & $-2,414$ & $-2,099$ & $-3,707$ \\
\hline Net credit to the private sector & 807 & 2,245 & 2,967 & 3,134 & 4,000 & 3,167 \\
\hline Medium- and long-term foreign liabilities & -303 & 351 & 35 & 38 & -374 & -215 \\
\hline Other net assets & 638 & -174 & 75 & 55 & 1,590 & 1,264 \\
\hline Liabilities to the private sector & 1,489 & 2,049 & 2,933 & 3,181 & 3,419 & 2,110 \\
\hline \multicolumn{7}{|l|}{ Memorandum items: } \\
\hline Credit to the private sector (in percent of GDP) & 19.4 & 22.5 & 23.7 & 24.8 & 27.4 & 28.9 \\
\hline Anunual growth rate & 14.4 & 26.6 & 27.1 & 27.6 & 27.6 & 18.5 \\
\hline
\end{tabular}

Sources: Central Bank of Nicaragua; and Fund staff estimates/projections.

1/ As stated in Country Report No. 04/347

2/ Includes Financiera Nicaraguense. 
Table 9. Nicaragua: Financial Soundness Indicators: Core and Encouraged Sets, and Structure and Performance (in percent)

\begin{tabular}{|c|c|c|c|c|}
\hline & 2002 & 2003 & 2004 & $20051 /$ \\
\hline \multicolumn{5}{|l|}{ I. Core Set (Deposit taking institutions) } \\
\hline \multicolumn{5}{|l|}{ Capital Adequacy } \\
\hline Regulatory capital to risk-weighted assets & 18.0 & 14.2 & 14.3 & 14.6 \\
\hline Regulatory Tier 1 capital to risk-weighted assets & 17.4 & 13.8 & 13.9 & 14.7 \\
\hline \multicolumn{5}{|l|}{ Asset Quality } \\
\hline Non performing loans to total gross loans & 3.4 & 2.7 & 2.2 & 4.3 \\
\hline Non performing loans to total gross loans $2 /$ & 12.6 & 12.7 & 9.3 & 8.0 \\
\hline Non performing loans net of provisions to capital & 37.1 & 44.9 & 31.2 & 21.2 \\
\hline \multicolumn{5}{|l|}{ Sectoral distribution of loans to total loans } \\
\hline Commercial & 26.3 & 25.3 & 28.8 & 26.8 \\
\hline Agricultural & 17.5 & 15.1 & 12.5 & 10.8 \\
\hline Consumer & 29.1 & 29.3 & 26.5 & 28.5 \\
\hline Construction & 9.2 & 10.4 & 12.4 & 13.0 \\
\hline Industrial & 11.4 & 11.8 & 10.5 & 10.2 \\
\hline Others & 6.4 & 8.2 & 9.3 & 10.7 \\
\hline \multicolumn{5}{|l|}{ Earnings and Profitability } \\
\hline Return on assets & 1.8 & 2.1 & 2.8 & 2.6 \\
\hline Return on equity & 23.9 & 29.2 & 34.9 & 29.5 \\
\hline Interest margin to assets & 8.6 & 9.1 & 8.4 & 7.9 \\
\hline Noninterest expenses to gross income & 48.9 & 47.6 & 66.6 & 69.0 \\
\hline \multicolumn{5}{|l|}{ Liquidity } \\
\hline Liquid assets to total assets & 19.9 & 21.1 & 20.6 & 19.9 \\
\hline Liquid assets to total short-term liabilities & 155.8 & 159.1 & 178.1 & 355.4 \\
\hline \multicolumn{5}{|l|}{ Exposure to FX risk } \\
\hline Net open position in foreign exchange to capital & 55.6 & 58.7 & 66.7 & 60.3 \\
\hline \multicolumn{5}{|l|}{ II. Encouraged Set (Deposit taking institutions) } \\
\hline Capital to assets & 55.6 & 58.7 & 66.7 & 60.3 \\
\hline Interest margin to total assets & 8.6 & 9.1 & 8.4 & 7.9 \\
\hline Foreign currency-denominated loans to total loans & 82.3 & 83.3 & 84.1 & 83.3 \\
\hline Foreign currency-denominated liabilities to total liabilities & 72.5 & 69.7 & 68.9 & 67.5 \\
\hline Foreign currency deposits (in percent of GIR) & 255.5 & 237.5 & 196.2 & 219.2 \\
\hline Ratio of real estate loans to total loans & 9.2 & 10.4 & 12.4 & 13.2 \\
\hline Large exposures to capital & 65.5 & 98.0 & 56.5 & 66.7 \\
\hline Personnel expenses to noninterest expenses & 37.5 & 37.8 & 41.7 & 41.9 \\
\hline Spread between reference lending and deposit rates & 12.7 & 12.7 & 13.4 & 13.3 \\
\hline Customer deposits to total (non-interbank) loans & 212.3 & 185.3 & 169.6 & 156.6 \\
\hline \multicolumn{5}{|l|}{ III. Structure and Performance of the Financial Sector } \\
\hline Number of institutions & 10 & 9 & 10 & 9 \\
\hline Total assets (in millions of cordobas) & 28,525 & 33,432 & 39,231 & 44,499 \\
\hline \multicolumn{5}{|l|}{ Bank concentration } \\
\hline \multicolumn{5}{|l|}{ Number of banks accounting for at least } \\
\hline 25 percent of total assets & 1 & 1 & 1 & 1 \\
\hline 75 percent of total assets & 9 & 8 & 9 & 8 \\
\hline \multicolumn{5}{|l|}{ Bank assets (percentage of GDP) } \\
\hline Private commercial & 50.0 & 54.0 & 54.0 & 53.8 \\
\hline Foreign banks & 0.0 & 0.0 & 0.2 & 0.3 \\
\hline \multicolumn{5}{|l|}{ Bank deposits (percentage of GDP) } \\
\hline Private commercial & 41.1 & 43.1 & 42.9 & 41.95 \\
\hline Foreign banks & $\ldots$ & $\ldots$ & $\ldots$ & 0.03 \\
\hline \multicolumn{5}{|l|}{ Dollarization and maturity structure } \\
\hline Banking system assets as percentage of GDP & 50.0 & 54.0 & 54.0 & 53.85 \\
\hline $\begin{array}{l}\text { Assets in foreign currency } \\
\text { (as percentage of banking system assets) }\end{array}$ & 49.3 & 52.5 & 56.7 & 60.2 \\
\hline \multicolumn{5}{|l|}{ Contingent and off-balance sheet accounts } \\
\hline (as percentage of total assets) & 6.5 & 8.2 & 9.1 & 10.2 \\
\hline
\end{tabular}


Table 10. Nicaragua: Balance of Payments

(In millions of U.S. dollars; unless otherwise indicated)

\begin{tabular}{|c|c|c|c|c|c|c|}
\hline & \multirow[t]{2}{*}{2002} & \multirow[t]{2}{*}{2003} & \multicolumn{2}{|l|}{$20041 /$} & \multirow{2}{*}{$\begin{array}{l}2005 \\
\text { Proj. }\end{array}$} & \multirow{2}{*}{$\begin{array}{l}2006 \\
\text { Proj. }\end{array}$} \\
\hline & & & Program 2/ & Actual & & \\
\hline Current account & -767 & -749 & -895 & -732 & -845 & -893 \\
\hline Trade balance & -918 & -972 & $-1,111$ & $-1,089$ & $-1,368$ & $-1,477$ \\
\hline Exports, f.o.b. & 917 & 1,050 & 1,114 & 1,363 & 1,543 & 1,754 \\
\hline Imports, f.o.b. & $-1,834$ & $-2,021$ & $-2,225$ & $-2,452$ & $-2,911$ & $-3,230$ \\
\hline Of which, oil imports & -253 & -328 & -380 & -426 & -615 & -717 \\
\hline Nonfactor services (net) & -112 & -106 & -100 & -110 & -130 & -135 \\
\hline Receipts & 226 & 258 & 270 & 290 & 330 & 370 \\
\hline Payments & -337 & -363 & -370 & -399 & -460 & -505 \\
\hline Official interest obligations 1 / & -138 & -121 & -119 & -122 & -46 & -65 \\
\hline Other current transactions (net) & 400 & 449 & 463 & 588 & 700 & 783 \\
\hline Factor services receipts & 9 & 7 & 8 & 9 & 19 & 28 \\
\hline Noninterest factor services payments & -71 & -77 & -80 & -80 & -82 & -85 \\
\hline Private transfers & 462 & 519 & 533 & 659 & 763 & 840 \\
\hline Of which: remittances & 377 & 439 & 489 & 519 & 623 & 700 \\
\hline Capital account & 575 & 575 & 704 & 651 & 823 & 1,021 \\
\hline Official (net) & 193 & 385 & 331 & 458 & 499 & 659 \\
\hline Official transfers & 248 & 286 & 261 & 307 & 310 & 320 \\
\hline Disbursements & 213 & 303 & 255 & 341 & 239 & 391 \\
\hline Amortization & -283 & -225 & -186 & -202 & -49 & -63 \\
\hline Other & 15 & 21 & 0 & 12 & -1 & 11 \\
\hline Other capital (private) & 383 & 190 & 373 & 193 & 324 & 362 \\
\hline Foreign direct investment & 220 & 213 & 261 & 250 & 229 & 279 \\
\hline Of which: privatization & 16 & 11 & 61 & 64 & 0 & 0 \\
\hline Financial system and other private capital flows & 163 & -23 & 112 & -57 & 95 & 84 \\
\hline Overall balance & -192 & -175 & -191 & -81 & -22 & 128 \\
\hline Change in external assets (- increase) & -85 & -69 & $\ldots$ & -166 & 22 & -128 \\
\hline Net change in arrears (decrease -) & -390 & 9 & $-1,442$ & $-1,402$ & $-1,416$ & 0 \\
\hline Exceptional financing & 667 & 235 & 1,653 & 1,649 & 1,416 & 0 \\
\hline \multicolumn{7}{|l|}{ Memorandum items: } \\
\hline Current account (in percent of GDP) & -19.1 & -18.1 & 20.5 & -16.1 & -16.9 & -16.7 \\
\hline Excluding interest obligations (in percent of GDP & -15.6 & -15.2 & -17.2 & -13.4 & -16 & -15 \\
\hline Non-oil, excluding interest (in percent of GDP) & -9.3 & -7.3 & $\ldots$ & -4.0 & -3.7 & -2.1 \\
\hline Gross reserves & 454 & 504 & 553 & 670 & 648 & 776 \\
\hline Gross reserves (in months of imports) & 2.8 & 2.1 & 2.8 & 2.8 & 2.3 & 2.5 \\
\hline Net international reserves (adjusted) & 64 & 83 & 102 & 211 & 226 & 311 \\
\hline Average oil price (US\$/bbl) & 25.0 & 28.9 & 34.5 & 37.8 & 54 & 62 \\
\hline GDP & 4,025 & 4,147 & 4,354 & 4,556 & 5,008 & 5,358 \\
\hline
\end{tabular}

Sources: Central Bank of Nicaragua; and Fund staff estimates/projections.

1/ Figures for 2004 and beyond reflect completion point under the HIPC initiative reached in January 2004.

2/ As stated in Country Report No. 04/347 
Table 11. Nicaragua: External Financing

(In millions of U.S. dollars)

\begin{tabular}{|c|c|c|c|c|c|c|c|}
\hline & \multirow[t]{2}{*}{2001} & \multirow[t]{2}{*}{2002} & \multirow[t]{2}{*}{2003} & \multicolumn{2}{|l|}{2004} & \multirow{2}{*}{$\begin{array}{l}2005 \\
\text { Prog. }\end{array}$} & \multirow{2}{*}{$\begin{array}{l}2006 \\
\text { Prog. }\end{array}$} \\
\hline & & & & Program 1/ & Actual & & \\
\hline Gross financing requirements & -826 & $-1,135$ & $-1,043$ & $-1,161$ & $-1,100$ & -872 & $-1,085$ \\
\hline Current account deficit (excluding official transfers) & -797 & -767 & -749 & -895 & -732 & -845 & -893 \\
\hline Debt amortization & -138 & -278 & -217 & -186 & -184 & -45 & -52 \\
\hline Net reserves accumulation, excluding IMF transactions & 114 & -85 & -69 & -73 & -166 & 22 & -128 \\
\hline IMF repurchases and repayments & -5 & -5 & -8 & -8 & -18 & -4 & -11 \\
\hline Gross financing sources & 826 & 1,135 & 1,043 & 1,161 & 1,100 & 872 & 1,085 \\
\hline Foreign direct investment (net) & 187 & 234 & 233 & 260 & 262 & 228 & 290 \\
\hline Debt financing from private creditors & -26 & 163 & -23 & 112 & -57 & 95 & 84 \\
\hline Financial system & 2 & -10 & -16 & 77 & -10 & 17 & 35 \\
\hline Portfolio investment (Cenis) & 14 & 1 & 0 & -44 & -1 & 1 & 0 \\
\hline Other net private capital flows & -42 & 172 & -7 & 79 & -47 & 78 & 49 \\
\hline Official transfers & 295 & 248 & 286 & 261 & 307 & 310 & 320 \\
\hline Disbursements (medium- and long-term loans) & 212 & 204 & 274 & 255 & 300 & 239 & 330 \\
\hline IMF disbursements & 0 & 9 & 29 & 61 & 41 & 0 & 61 \\
\hline Net change in arrears & -377 & -390 & 9 & $-1,442$ & $-1,402$ & $-1,416$ & 0 \\
\hline Exceptional financing & 535 & 667 & 235 & 1653.4 & 1,649 & 1,416 & 0 \\
\hline
\end{tabular}

Sources: Central Bank of Nicaragua; and Fund staff estimates/projections.

1/ As stated in Country Report No. 04/347 
Table 12. Nicaragua: Indicators of Fund Credit

(In units indicated)

\begin{tabular}{|c|c|c|c|c|c|c|c|c|c|}
\hline & 2001 & 2002 & 2003 & 2004 & 2005 & 2006 & 2007 & 2008 & 2009 \\
\hline \multicolumn{10}{|l|}{$\begin{array}{l}\text { Stock of existing credit and } \\
\text { prospective credit Fund credit 1/ }\end{array}$} \\
\hline In millions of SDRs & 125.33 & 128.291 & 143.5 & 159.5 & 140.5 & 117.4 & 94.4 & 70.2 & 50.0 \\
\hline In percent of quota & 96.4 & 98.7 & 110.4 & 122.7 & 108.1 & 90.3 & 72.6 & 54.0 & 38.5 \\
\hline In percent of exports of goods and services & 8.9 & 8.4 & 7.5 & 6.3 & 5.2 & 3.8 & 2.8 & 1.9 & 1.2 \\
\hline In percent of external debt & 1.4 & 1.3 & 1.3 & 3.6 & 3.1 & 2.4 & 1.8 & 1.2 & 0.8 \\
\hline In percent of gross reserves & 25.9 & 21.0 & 19.4 & 15.4 & 14.9 & 10.4 & 7.4 & 4.9 & 3.0 \\
\hline \multicolumn{10}{|l|}{$\begin{array}{l}\text { Obligations to the Fund from existing } \\
\text { and prospective Fund Arrangements }\end{array}$} \\
\hline In millions of SDRs & 4.6 & 4.6 & 6.4 & 12.6 & 19.4 & 8.9 & 11.6 & 13.2 & 15.5 \\
\hline In percent of quota & 3.6 & 3.6 & 4.9 & 9.7 & 14.9 & 6.8 & 8.9 & 10.2 & 11.9 \\
\hline In percent of exports of goods and services & 0.3 & 0.3 & 0.3 & 0.5 & 0.7 & 0.3 & 0.3 & 0.4 & 0.4 \\
\hline In percent of external debt & 0.1 & 0.0 & 0.1 & 0.3 & 0.4 & 0.2 & 0.2 & 0.2 & 0.3 \\
\hline In percent of gross reserves & 1.0 & 0.8 & 0.9 & 1.2 & 2.1 & 0.8 & 0.9 & 0.9 & 0.9 \\
\hline
\end{tabular}

Sources: IMF, Finance Department

1/ End of period 
Table 13. Nicaragua: Medium-term Macroeconomic Framework (Baseline)

\begin{tabular}{|c|c|c|c|c|c|c|c|}
\hline & \multirow[b]{2}{*}{2004} & \multicolumn{6}{|c|}{ Projected } \\
\hline & & 2005 & 2006 & 2007 & 2008 & 2009 & 2010 \\
\hline GDP growth (percent) & 5.1 & 4.0 & 3.7 & 4.3 & 4.6 & 4.8 & 5.0 \\
\hline CPI (eop, in percent) & 9.3 & 10.5 & 7.3 & 5.0 & 3.0 & 3.0 & 3.0 \\
\hline CPI (avg, in percent) & 8.5 & 9.7 & 8.8 & 6.2 & 4.0 & 3.0 & 3.0 \\
\hline GDP deflator (percent) & 10.2 & 10.9 & 8.3 & 5.0 & 3.0 & 2.5 & 2.5 \\
\hline \multirow[t]{2}{*}{ Terms of trade (deterioration -) } & -3.6 & -1.4 & -2.5 & -1.4 & -0.6 & -0.5 & -0.5 \\
\hline & \multicolumn{7}{|c|}{ (In millions of US\$) } \\
\hline Current account & -732 & -845 & -893 & -896 & -881 & -874 & -867 \\
\hline (in percent of GDP) & -16.1 & -16.9 & -16.7 & -16.0 & -15.2 & -14.5 & -13.7 \\
\hline Exports of goods, f.o.b & 1,363 & 1,543 & 1,754 & 1,915 & 2,080 & 2,261 & 2,468 \\
\hline Imports of goods, f.o.b. & $-2,452$ & $-2,911$ & $-3,230$ & $-3,419$ & $-3,611$ & $-3,834$ & $-4,080$ \\
\hline \multirow[t]{2}{*}{ Gross international reserves } & 670 & 648 & 776 & 875 & 987 & 1,142 & 1,316 \\
\hline & \multicolumn{7}{|c|}{ (In percent of GDP) } \\
\hline \multicolumn{8}{|l|}{ Combined public sector } \\
\hline Revenue & 22.6 & 22.9 & 23.1 & 23.1 & 23.2 & 23.3 & 23.4 \\
\hline Expenditure & 27.8 & 28.2 & 28.3 & 27.5 & 27.5 & 27.2 & 26.9 \\
\hline \multicolumn{8}{|l|}{ Of which: } \\
\hline Interest & 2.1 & 2.0 & 2.0 & 2.0 & 2.0 & 1.8 & 1.5 \\
\hline Operational balance of central bank & -1.4 & -0.7 & -0.9 & -0.7 & -0.6 & -0.6 & -0.5 \\
\hline Primary balance & -3.2 & -3.6 & -3.5 & -2.8 & -2.6 & -2.4 & -2.3 \\
\hline Overall balance before grants & -6.3 & -6.0 & -6.0 & -5.2 & -4.9 & -4.5 & -4.1 \\
\hline Grants & 3.6 & 3.8 & 3.8 & 3.8 & 3.7 & 3.6 & 3.5 \\
\hline Overall balance after grants & -2.8 & -2.2 & -2.2 & -1.3 & -1.2 & -0.9 & -0.6 \\
\hline Combined public sector debt $\mathbf{1}$ / & 92.7 & 86.5 & 83.4 & 81.1 & 80.1 & 78.5 & 76.9 \\
\hline Domestic debt & 29.4 & 25.2 & 20.0 & 15.2 & 11.7 & 8.3 & 5.6 \\
\hline External debt & 63.3 & 61.3 & 63.4 & 65.9 & 68.3 & 70.2 & 71.3 \\
\hline Investment & 28.3 & 28.9 & 28.3 & 28.5 & 28.8 & 29.0 & 29.2 \\
\hline Private sector & 21.2 & 22.3 & 21.9 & 22.1 & 22.5 & 22.7 & 23.1 \\
\hline Public sector & 7.1 & 6.6 & 6.4 & 6.4 & 6.3 & 6.3 & 6.1 \\
\hline Savings & 12.2 & 12.0 & 11.6 & 12.5 & 13.6 & 14.5 & 15.5 \\
\hline Private sector & 7.7 & 7.2 & 7.0 & 7.1 & 8.3 & 8.8 & 9.6 \\
\hline Public sector & 4.5 & 4.8 & 4.6 & 5.4 & 5.3 & 5.7 & 5.9 \\
\hline \multicolumn{8}{|l|}{ Memorandum items: } \\
\hline Nominal GDP (C\$ mn) & 72,603 & 83,793 & 94,120 & 103,075 & 111,051 & 119,291 & 128,387 \\
\hline GDP (US\$ mn) & 4,556 & 5,008 & 5,358 & 5,587 & 5,789 & 6,037 & 6,308 \\
\hline \multicolumn{8}{|l|}{ Gross reserves } \\
\hline (in months of imports of G\&NFS) & 2.8 & 2.3 & 2.5 & 2.7 & 2.8 & 3.1 & 3.3 \\
\hline NIR (adjusted) & 211 & 226 & 311 & 381 & 451 & 536 & 626 \\
\hline
\end{tabular}

Sources: Central Bank of Nicaragua; Ministry of Finance; and Fund staff estimates/projections.

1/ Assuming full delivery of full HIPC relief for 2004. Measured at face value. 
Table 14. Nicaragua: Medium-term Macroeconomic Framework (Alternative)

\begin{tabular}{|c|c|c|c|c|c|c|c|}
\hline & & & & Proje & ted & & \\
\hline & 2004 & 2005 & 2006 & 2007 & 2008 & 2009 & 2010 \\
\hline GDP growth (percent) & 5.1 & 4.0 & 3.2 & 2.5 & 2.5 & 2.0 & 2.0 \\
\hline CPI (eop, in percent) & 9.3 & 10.5 & 11.0 & 11.5 & 11.5 & 11.8 & 12.5 \\
\hline CPI (avg, in percent) & 8.5 & 9.7 & 10.8 & 11.3 & 11.5 & 11.7 & 12.2 \\
\hline GDP deflator (percent) & 10.2 & 10.9 & 10.6 & 11.1 & 11.3 & 11.5 & 12.0 \\
\hline Terms of trade (deterioration -) & -3.6 & -1.4 & -2.5 & -1.4 & -0.6 & -0.5 & -0.5 \\
\hline Current account & -732 & -845 & -916 & -961 & -975 & -966 & -951 \\
\hline (in percent of GDP) & -16.1 & -16.9 & -16.8 & -16.6 & -16.2 & -15.4 & -14.6 \\
\hline Exports of goods, f.o.b & 1,363 & 1,543 & 1,732 & 1,867 & 2,002 & 2,149 & 2,316 \\
\hline Imports of goods, f.o.b. & $-2,452$ & $-2,911$ & $-3,221$ & $-3,415$ & $-3,600$ & $-3,790$ & $-3,993$ \\
\hline Gross international reserves & 670 & 648 & 641 & 546 & 459 & 409 & 371 \\
\hline Combined public sector & & & & & & & \\
\hline Revenue & 22.6 & 22.9 & 22.7 & 22.7 & 22.4 & 22.2 & 22.0 \\
\hline Expenditure & 27.8 & 28.2 & 29.9 & 30.3 & 30.2 & 30.5 & 30.8 \\
\hline Of which: & & & & & & & \\
\hline Interest & 2.1 & 2.0 & 1.9 & 3.7 & 3.7 & 4.0 & 4.4 \\
\hline Operational balance of central bank & -1.4 & -0.7 & -0.9 & -1.2 & -1.4 & -1.6 & -1.7 \\
\hline Primary balance & -3.2 & -3.6 & -5.5 & -4.2 & -4.3 & -4.6 & -4.7 \\
\hline Overall balance before grants & -6.3 & -6.0 & -8.0 & -8.7 & -9.0 & -9.7 & -10.3 \\
\hline Grants & 3.6 & 3.8 & 3.7 & 3.1 & 3.0 & 2.9 & 2.8 \\
\hline Overall balance after grants & -2.8 & -2.2 & -4.3 & -5.5 & -6.0 & -6.8 & -7.5 \\
\hline Combined public sector debt 1 / & 92.7 & 84.7 & 81.5 & 81.7 & 84.4 & 88.9 & 94.9 \\
\hline Domestic debt & 29.4 & 23.3 & 20.8 & 21.3 & 23.5 & 27.2 & 33.0 \\
\hline External debt & 63.3 & 61.3 & 60.7 & 60.4 & 61.0 & 61.7 & 62.0 \\
\hline Investment & 28.3 & 28.9 & 28.2 & 26.8 & 26.0 & 24.5 & 23.3 \\
\hline Private sector & 21.2 & 22.3 & 20.8 & 19.7 & 18.9 & 17.4 & 16.1 \\
\hline Public sector & 7.1 & 6.6 & 7.4 & 7.1 & 7.1 & 7.1 & 7.1 \\
\hline Savings & 12.2 & 12.0 & 11.3 & 10.2 & 9.9 & 9.1 & 8.7 \\
\hline Private sector & 7.7 & 7.2 & 8.0 & 8.0 & 8.0 & 8.0 & 8.0 \\
\hline Public sector & 4.5 & 4.8 & 3.3 & 2.2 & 1.8 & 1.1 & 0.6 \\
\hline Memorandum items: & & & & & & & \\
\hline Nominal GDP (C\$ mn) & 72,603 & 83,793 & 95,641 & 108,913 & 124,251 & 141,311 & 161,433 \\
\hline GDP (US\$ mn) & 4,556 & 5,008 & 5,442 & 5,442 & 5,781 & 6,033 & 6,268 \\
\hline Gross reserves & & & & & & & \\
\hline (in months of imports of G\&NFS) & 2.8 & 2.3 & 2.0 & 1.6 & 1.3 & 1.1 & 1.0 \\
\hline NIR (adjusted) & 211 & 226 & 210 & 139 & 50 & -3 & -77 \\
\hline
\end{tabular}

Sources: Central Bank of Nicaragua; Ministry of Finance; and Fund staff estimates/projections.

$1 /$ Measured at face value. 
Table 15. Nicaragua: Millennium Development Goals 1/

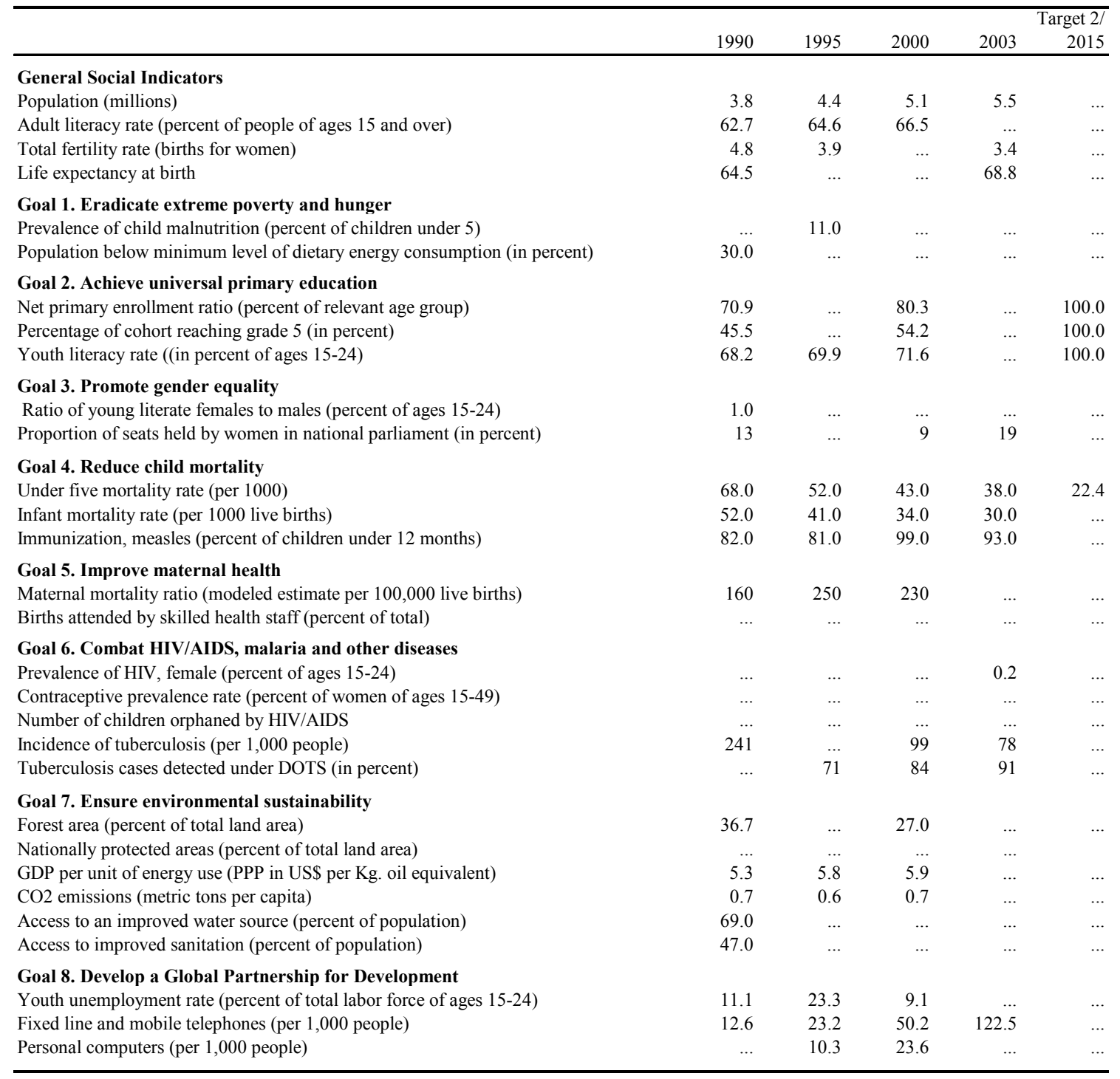

Source: World Development Indicators database, December 2005.

$1 /$ Includes only indicators for which data is available for any given year.

2/ Targets are indicated quantitatively, wherever possible, but specifics are described in the goals sections.

Goal 1 target: Halve between 1990 and 2015, the proportion of people who suffer from hunger.

Goal 2 target: Ensure that, by 2015, children everywhere will be able to complete a full course of primary schooling.

Goal 3 target: Eliminate gender disparity, in primary and secondary education preferably by 2005 and to all

levels of education no later than 2015 .

Goal 4 target: Reduce by two-thirds, between 1990 and 2015, the under-five mortality rate.

Goal 5 target: Reduce by three quarters, between 1990 and 2015, the maternal mortality ratio.

Goal 6 targets: Have halted by 2015, and begun to reverse, the spread of HIV/AIDS. Have halted by 2015, and begun

to reverse, the incidence of malaria and other major diseases.

Goal 7 targets: Integrate the principles of sustainable development into country policies and programs and reverse the loss

of environmental resources. Halve by 2015 , the proportion of people without sustainable access to safe drinking water.

Goal 8 targets: Develop further an open rule-based, predictable, non-discriminatory trading and financial system. Address the special needs of the least developed countries and landlocked countries and small islands developing states. Deal comprehensively with the debt problems of developing countriesthrough national and international measures in order to make debt sustainable work for youth. In cooperation with the private sector, make available the benefits of new technologies, in the long term. In cooperation with developing countries, develop and implement strategies for decent and productive specially information and communications. 
NiCARAGUA-Fund RELATIONS

(As of November 30, 2005)

I. Membership Status: Joined: 03/14/1946; Article VIII since 7/30/1964.

II. General Resources Account:

SDR Million

Quota

Fund Holdings of Currency

III. SDR Department:

Net cumulative allocation Holdings

SDR Million

19.48

0.08

130.00

130.01

Percent

of Quota

100.00

100.01

Percent

of Allocation

100.00

0.40

IV. Outstanding Purchases and Loans:

ESAF/PRGF arrangements

SDR Million

140.48

Percent of Quota

108.06

V. Financial Arrangements:

$\begin{array}{lrrrr}\text { Type } & \begin{array}{r}\text { Approval } \\ \text { Date }\end{array} & \begin{array}{r}\text { Expiration } \\ \text { Date }\end{array} & \begin{array}{r}\text { Amount } \\ \text { Approved } \\ \text { (SDR Million) }\end{array} & \begin{array}{r}\text { Amount } \\ \text { Drawn } \\ \text { (SDR Million) }\end{array} \\ \text { PRGF } & 12 / 13 / 2002 & 12 / 12 / 2005 & 97.50 & 55.72 \\ \text { ESAF/PRGF } & 03 / 18 / 1998 & 03 / 17 / 2002 & 148.96 & 115.32 \\ \text { ESAF } & 06 / 24 / 1994 & 06 / 23 / 1997 & 120.12 & 20.02\end{array}$

VI. Projected Payments to Fund (with Board-approved HIPC Assistance):

(SDR million; based on existing use of resources and present holdings of SDRs)

Forthcoming

\begin{tabular}{rrrrr}
\hline $\mathbf{2 0 0 5}$ & $\mathbf{2 0 0 6}$ & $\mathbf{2 0 0 7}$ & $\mathbf{2 0 0 8}$ & $\mathbf{2 0 0 9}$ \\
& 23.06 & 23.06 & 24.17 & 20.18 \\
$\underline{0.36}$ & $\underline{1.22}$ & $\underline{1.11}$ & $\underline{1.00}$ & $\underline{0.88}$ \\
$\underline{0.36}$ & $\underline{8.71}$ & $\underline{11.14}$ & $\underline{12.78}$ & $\underline{15.05}$
\end{tabular}




\section{Implementation of HIPC Initiative:}

\section{Enhanced \\ Framework}

Commitment of HIPC assistance

Decision point date

December 2000

Assistance committed

by all creditors (US\$ million) ${ }^{1}$

Of which: IMF assistance (US\$ million)

82.20

(SDR equivalent in millions)

63.54

Completion point date

January 2004

Disbursement of IMF assistance (SDR million)

Assistance disbursed to the member

Interim assistance

Completion point balance

60.99

Additional disbursement of interest income ${ }^{2}$

Total Disbursements

71.16

\section{Safeguards Assessments:}

The updated assessment of the BCN, which was completed on August 29, 2003, found that it continues to maintain strong safeguards and has taken steps to implement the recommendations made in the 2001 safeguards assessment. The main recommendations of the 2003 safeguards assessment and included the adoption of International Accounting Standards (IAS). A task force has been established by the BCN to ensure adequate training for the transition to full IAS. The updated assessment's recommendations have been implemented, with the exception of the adoption of full IAS, which is planned for the 2004 financial statements.

\section{Exchange Rate Arrangements:}

In December 1995, the Monetary Board of the central bank approved the unification of the exchange rate system effective January 1, 1996. With the unification of the exchange rate, all previous exchange restrictions on payments and transfers for current international transactions and multiple currency practices were eliminated. The central bank buys/sells any

\footnotetext{
${ }^{1}$ Assistance committed under the original framework is expressed in net present value (NPV) terms at the completion point, and assistance committed under the enhanced framework is expressed in NPV terms at the decision point.

${ }^{2}$ Under the enhanced framework, an additional disbursement is made at the completion point corresponding to interest income earned on the amount committed at the decision point but not disbursed during the interim period.
} 
amount of foreign currency from/to financial institutions at the official exchange rate, and implements a crawling peg system. The rate of crawl was reduced from an annual rate of 6 percent in 2003 to 5 percent in 2004 and has been maintained at this level since.

As of October 31, 2005, the exchange rate in the official market was C $\$ 17.00$ per U.S. dollar.

\section{Article IV Consultation:}

The last consultation was completed by the Executive Board on November 19, 2002 (IMF Country Report No. 03/24). It is expected that the next Article IV consultation with Nicaragua will be held on a standard 24-month cycle subject to the provisions of the decision on consultation cycles approved by the Board on July 15, 2002.

\section{Technical Assistance:}

\section{Dept. $\quad$ Purpose}

FAD TA mission on revenue administration

FAD/LEG TA mission on fiscal responsibility legislation

FAD Tax administration expert in Managua

FAD Tax administration

FAD Tax reform

FAD ROSC fiscal transparency module

FAD Mission to review energy taxation and advise on the system of exemptions, exonerations, tax holidays, and other incentives with regard to the major indirect taxes major indirect taxes

\section{LEG Banking resolution}

MFD Banking legislation and banking supervision

MFD Banking supervision

MFD Banking restructuring

MFD Assessing CBN's debt sustainability and streamline its open market operations, with special focus on providing liquidity to CBN's securities and increase their marketability

MFD Workshop on payments system

MFD Consultancy on introducing an exchange rate band

OIA Mission to assess the management, organizational structure, and internal control systems and procedures of the Superintendency of Banks and Other Financial Institutions

\author{
Time of Delivery \\ November 2005 \\ September 2004 \\ April 2004-2006 \\ October 2003 \\ March 2003 \\ November 2001 \\ January 2000
}

July 2004

September 2003

October 2002

November 2001

July 2001

January 27-29, 1999

October 1999

February 2000 
Dept. Purpose

STA ROSC Data Module

STA Monetary and finance statistics

STA National accounts

STA Monetary and finance statistics

STA Monetary and finance statistics

STA Mission on money and banking statistics
Time of Delivery

January 2005

November 2003

November 2001

November 2001

September 2001

June-July 1999

\section{Resident Representative:}

Mr. Humberto Arbulú-Neira assumed the position of resident representative in Nicaragua in August 2004. 
NiCARAGUA-RELATIONS With THE WORLd BANK GROUP

(As of October 31, 2005)

I. Financial Relations

A. Bank Loans and IDA Credits

(In millions of U.S. dollars)

\section{IBRD IDA Total}

$\begin{array}{lrrr}\text { Fully disbursed loans and credits } & 229.6 & 1,133.0 & 1,362.6 \\ \text { Credits/loans currently undisbursed } & 0.0 & 131.0 & 131.0\end{array}$

\begin{tabular}{lrrr} 
Total (net of cancellations) & $\mathbf{2 2 9 . 6}$ & $\mathbf{1 , 2 6 4 . 0}$ & $\mathbf{1 , 4 9 3 . 6}$ \\
Of which & & & \\
Repaid & 223.9 & 39.8 & 263.7 \\
Borrower obligations & 0.0 & $1,142.6$ & $1,142.6$ \\
\hline
\end{tabular}

\section{B. World Bank/IDA Loan Commitments and Disbursements}

1. As of October 31, 2005, total loans/credits disbursed and undisbursed from the Bank/IDA amounted to US\$1,493.6 million. The currently active portfolio consists of 14 projects for a total commitment of US\$373.2 million, of which US\$131 million remain to be disbursed. The World Bank Board of Directors is expected to approve the Second Agricultural Technology Project at the end of November 2005, for US\$12 million. The project's principal objective is to provide rural households and communities with broader access to sustainable agricultural, forestry and natural resource management services and innovations, thereby stimulating higher agricultural productivity in Nicaragua.

\section{Plans for the NeXt 12 Months}

2. IDA completed a new Interim Strategy Note (ISN) in July 2005, which proposes an extension to the program implemented in the last CAS (2003-2005). This two-year period will allow for the continuation of successful operations that support the Government's emphasis on growth to address poverty and, in tandem, bring the CAS in-line with Nicaragua's election cycle. In terms of future lending, the IDA allocation for FY06 is SDR 40 million (US\$58.5 million at current exchange rates), and a similar amount is foreseen for FY07, provided that there are no major changes in policy stance and performance. In alignment with the priorities identified in the Government's National Development Plan (which replaces the earlier PRSP), the ISN envisages projects in rural infrastructure, competitiveness-strengthening and health. Further budget support would be provided only if key measures agreed to in the PRSC policy matrix are implemented. 
NICARAGUA-RELATIONS WITH THE INTER-AMERICAN DEVELOPMENT BANK

(As of November 30, 2005)

I. Financial Relations

A. Statement of IDB Loans

(In millions of U.S. dollars)

\begin{tabular}{llr}
\hline Year & Purpose & Amount \\
\hline 2004 & Plan Puebla-Panama roads program for competitiveness & 40.0 \\
& Roads Program for Competitiveness II & 40.0 \\
& Support to MIFAMILIA & 3.0 \\
& Support to SECEP & 7.0 \\
& Citizen's security & 7.2 \\
& Population and housing Census & 6.6 \\
& Education for children and adults & 10.0 \\
& Mother and child health & 30.0 \\
& & \\
(Programming) & 30.0 \\
& Programa sectorial social de apoyo a la ERCERP & 45.0 \\
& Programa de Inversión Social - FISE & 40.1 \\
\hline
\end{tabular}

\section{B. IDB Loan Commitments and Disbursements}

As of November 30, 2005, there are 39 projects in the Bank's portfolio for US\$803.1 million, with an undisbursed balance of US\$399.6 million. During the SFO (Special Fund Operations) allocation period 2004-2005, Nicaragua received US\$220.0 million, including US\$40.0 million of the re-allocation exercise. For the SFO allocation period 2006-2007, the original assignation is estimated in US\$189.0 million.

The total HIPC debt relief from the IDB to Nicaragua reaches US\$723.8 million. For 2005, relief of US\$34.9 million is projected.

\section{Recent Technical Assistance}

As of November 30, 2005, there are 30 nonreimbursable technical cooperation in execution for US $\$ 8.1$ million. The Bank's program for 2005-06 also includes new nonreimbursable technical cooperation projects for US\$2.1 million.

\section{RECENT AgREEMENTS}

Nicaragua's country strategy update for 2005 was approved by the Board in May. A new country strategy will be prepared in 2007. 


\section{NiCARAGUA-STATISTICAL ISSUES}

\section{Introduction}

1. Nicaragua's economic data reported to the Fund are generally adequate for surveillance purposes. There are some statistical shortcomings in all sectors, which are being addressed with technical assistance from the Fund, IDA, IDB, and USAID. The authorities are cooperative in providing data to the Fund in a timely fashion, and in some cases, on a daily basis. The Central Bank of Nicaragua $(\mathrm{BCN})$ produces a monthly bulletin and an annual report covering developments in the monetary, fiscal, external, and real sectors. The $\mathrm{BCN}$ provides statistical information to the general public through the Internet. Among other data the BCN has in its site the RED tables in agreement with Fund standard and a Debt report.

2. However, there are still problems of consistency among sectors, particularly with respect to the fiscal deficit financing. Additionally, adequate monetary statistics are not fully in use yet notwithstanding a long and intense TA to make them available for surveillance and program purposes.

3. The Nicaraguan authorities participated in a ROSC data module (January 2005), signaled their interest in participating in the General Data Dissemination System (GDDS), and formally began participation in February 2005. It is hoped that participation will spur strengthening of the country's statistical system, and provide a framework for channeling technical assistance resources optimally.

\section{Real Sector}

4. Real sector statistics have improved substantially and GDP quarterly statistics are about to be made available.

- $\quad$ The national accounts estimates were revised and adopted in March 2004 The revised accounts allow a better assessment of economic developments and prospects, although there remain certain deficiencies in the coverage of services.

- $\quad$ National Accounts: The Central Bank of Nicaragua $(\mathrm{BCN})$ provides annual data by sectors on national accounts in current and constant (1994) prices (with a 10-month lag). The authorities make the first data revision in the second quarter of the following year.

- $\quad$ The consumer price index (CPI) with expenditure weights derived from a (1998/99) household expenditure survey was introduced in 2001. The CPI covers Managua and eight other cities. Expenditures (weights) and prices in rural areas are excluded.

- Low response rates to price surveys for the CPI and the treatment of missing values and quality changes require review. 
- The consumer price index (CPI) is reported on a regular and timely basis. The $\mathrm{BCN}$ publishes monthly data on $C P I$ on the website www.ben.gob.ni with $1 \frac{1}{2}$ weeks lag.

- $\quad$ Exchange Rates: The $\mathrm{BCN}$ publishes monthly exchange rate data on the website www.ben.gob.ni.

\section{Monetary accounts}

5. Monetary accounts are generally adequate and have benefited TA. However, there are problems of consistency with respect to other sectors and particularly with the fiscal sector. In this respect, the deficit financing is particularly a problem.

- $\quad$ The monetary sector covers the accounts of the central bank $(\mathrm{BCN})$, the commercial banks (6), and the Financiera Nicaraguense de Inversiones (FNI, a second tier bank). These data are compiled by the BCN (Economic Studies Department).

- The commercial bank sector is comprised by: Banco de la Producción (BANPRO), Banco de Crédito Centroamericano (BANCENTRO), Banco de América Central (BAC), Banco de Finanzas (BDF), and Banco de la Exportación (BANEXPO).

- There are six other very small financial institutions that are not included in the coverage of the financial sector statistics.

- Daily information on the BCN accounts is reported by e-mail (one-day lag). However, the end of month information can be revised and the lag can be three to five days. Monthly information on the commercial banks and FNI accounts are reported on a monthly basis (two to three months lag).

- Data on the financial system accounts are prepared by the BCN (two to three months lag). Information on the $\mathrm{BCN}$ accounts can be found at the $\mathrm{BCN}$ internet website: www.ben.gob.ni.

\section{Balance of payments}

6. Balance of payments statistics are compiled in broad conformity with the fifth edition of the Balance of Payments Manual (BPM5) since 1995, within the limits set by the availability of information sources. Nicaragua sent methodology notes describing the compiling methods for balance of payments statistics which were included in Part 3 of the 2002 Balance of Payments Statistics Yearbook.

- Data covers Nicaragua's Balance of Payments statistics and various statistics related to the external debt. 
- With few exceptions, all data are provided quarterly. Monthly updates on exports and imports and condensed BOP tables are available from the BCN website (www.ben.gob.ni), with varying lags. Debt data are updated continuously at the $\mathrm{BCN}$ and are regularly available.

- $\quad$ Balance of payments statistics provided by the Department for International Studies at the Central Bank of Nicaragua.

- $\quad$ Servicably external debt statistics are provided by the Administration for External Liabilities at the CBN. Improvement of coverage is needed for external debt of public enterprises, of banks, and of the private sector.

- Nicaragua started compiling International Investment Position in 2005. Series for the period 2001-2004 are available on the CBN website.

\section{Government finance}

7. The Ministry of Finance (MoF) disseminates government finance statistics (GFS) covering only the central administration. The MoF also compiles annual GFS for the nonfinancial public sector (NFPS) for internal use and for reporting to the Western Hemisphere Department (WHD). The Central Bank of Nicaragua (CBN) does report budgetary central government data, although with considerable delay, for publication in the International Financial Statistics (IFS). Neither the MoF nor the CBH has reported GFS data for the Government Finance Statistics Yearbook (GFSY) recently.

8. The fiscal ROSC mission in 2002 and the data ROSC mission in 2005 both found that fiscal data in Nicaragua have serious weaknesses. The GFS issues related to coverage and sectorization can be explained to some extent by the Public Administration Law, which excludes the judicial and legislative branches from the data coverage of the central administration. The fiscal data also present large discrepancies between the overall balance compiled by the $\mathrm{MoF}$ and the financing data compiled by the $\mathrm{CBH}$. Therefore, stronger collaboration is needed between the MoF and the central bank to derive accurate and timely estimates of external financing of the nonfinancial public sector. In general, these data are not fully aligned with international standards, and there is no plan to migrate to the Government Finance Statistics Manual 2001 (GFSM 2001). The July 28-August 14, 2004 GFS mission produced a plan of action to improve fiscal data and proposed the creation of a working group for GFS compilation to implement that plan. The mission also recommended that the envisaged Integrated System of Financial Management be made to support the compilation of GFS data and gradual migration to the GFSM 2001. 
NICARAGUA: TABLE OF COMMON INDICATORS REQUIRED FOR SURVEILLANCE

(As OF DECEMBER 19, 2005)

\begin{tabular}{|c|c|c|c|c|c|c|c|}
\hline & \multirow{2}{*}{$\begin{array}{c}\text { Date of } \\
\text { latest } \\
\text { observation }\end{array}$} & \multirow{2}{*}{$\begin{array}{l}\text { Date } \\
\text { received }\end{array}$} & \multirow{2}{*}{$\begin{array}{c}\text { Frequency } \\
\text { of } \\
\text { Data }^{6}\end{array}$} & \multirow{2}{*}{$\begin{array}{l}\text { Frequency } \\
\quad \text { of } \\
\text { Reporting }^{6}\end{array}$} & \multirow{2}{*}{$\begin{array}{c}\text { Frequency } \\
\text { of } \\
\text { publication }\end{array}$} & \multicolumn{2}{|c|}{ Memo Items: } \\
\hline & & & & & & $\begin{array}{c}\text { Data Quality - } \\
\text { Methodological } \\
\text { soundness }\end{array}$ & $\begin{array}{l}\text { Data Quality - } \\
\text { Accuracy and } \\
\text { reliability }\end{array}$ \\
\hline Exchange Rates & $12 / 15 / 05$ & $12 / 16 / 05$ & $\mathrm{D}$ & $\mathrm{D}$ & $\mathrm{D}$ & & \\
\hline $\begin{array}{l}\text { International Reserve Assets and Reserve Liabilities } \\
\text { of the Monetary Authorities } 1\end{array}$ & $12 / 15 / 05$ & $12 / 16 / 05$ & $\mathrm{D}$ & $\mathrm{D}$ & $\mathrm{D}$ & & \\
\hline Reserve/Base Money & $12 / 15 / 05$ & $12 / 16 / 05$ & $\mathrm{D}$ & $\mathrm{D}$ & $\mathrm{D}$ & \multirow{4}{*}{$\mathrm{O}, \mathrm{LO}, \mathrm{LO}, \mathrm{LO}$} & \multirow{4}{*}{ LO, O, LO, LO, LO } \\
\hline Broad Money & $12 / 9 / 05$ & $12 / 16 / 05$ & $\mathrm{D}$ & $\mathrm{W}$ & $\mathrm{W}$ & & \\
\hline Central Bank Balance Sheet & $12 / 15 / 05$ & $12 / 16 / 05$ & $\mathrm{D}$ & $\mathrm{D}$ & $\mathrm{D}$ & & \\
\hline Consolidated Balance Sheet of the Banking System & $12 / 12 / 05$ & $12 / 12 / 05$ & Q & Q & $\mathrm{Q}$ & & \\
\hline Interest Rates ${ }^{2}$ & $12 / 9 / 05$ & $12 / 16 / 05$ & W & W & W & & \\
\hline Consumer Price Index & $10 / 05$ & $11 / 7 / 05$ & M & M & $\mathrm{M}$ & $\mathrm{O}, \mathrm{LO}, \mathrm{LO}, \mathrm{LO}$ & $\mathrm{LO}, \mathrm{LO}, \mathrm{LO}, \mathrm{O}, \mathrm{LO}$ \\
\hline $\begin{array}{l}\text { Revenue, Expenditure, Balance and Composition of } \\
\text { Financing }{ }^{3} \text { - General Government }\end{array}$ & $10 / 30 / 05$ & $10 / 10 / 05$ & M & M & $\mathrm{M}$ & \multirow[t]{2}{*}{ LO, LNO, LNO, LO } & \multirow[t]{2}{*}{$\mathrm{O}, \mathrm{O}, \mathrm{O}, \mathrm{O}, \mathrm{LO}$} \\
\hline $\begin{array}{l}\text { Revenue, Expenditure, Balance and Composition of } \\
\text { Financing }{ }^{3} \text { - Central Government }\end{array}$ & $10 / 30 / 05$ & $10 / 10 / 05$ & M & M & M & & \\
\hline $\begin{array}{l}\text { Stocks of Central Government and Central } \\
\text { Government-Guaranteed Debt }\end{array}$ & $6 / 30 / 05$ & $9 / 15 / 05$ & Q & Q & Q & & \\
\hline External Current Account Balance & $12 / 04$ & $2 / 05$ & A & A & A & \multirow[t]{2}{*}{ LO, LO, LNO, LO } & \multirow[t]{2}{*}{$\mathrm{LO}, \mathrm{O}, \mathrm{LO}, \mathrm{LO}, \mathrm{LO}$} \\
\hline Exports and Imports of Goods and Services & $12 / 04$ & $2 / 05$ & A & A & A & & \\
\hline GDP/GNP & 2004 & $3 / 05$ & A & A & A & $\mathrm{O}, \mathrm{O}, \mathrm{O}, \mathrm{LO}$ & $\mathrm{LO}, \mathrm{O}, \mathrm{LO}, \mathrm{O}, \mathrm{LNO}$ \\
\hline Gross External Debt & $6 / 31 / 05$ & $9 / 15 / 04$ & $\mathrm{Q}$ & $\mathrm{Q}$ & $\mathrm{Q}$ & & \\
\hline
\end{tabular}

${ }^{1}$ Includes reserve assets pledged or otherwise encumbered as well as net derivative positions.

${ }^{2}$ Both market-based and officially-determined, including discount rates, money market rates, rates on treasury bills, notes and bonds.

${ }^{3}$ Foreign, domestic bank, and domestic nonbank financing.

${ }^{4}$ The general government consists of the central government (budgetary funds, extra budgetary funds, and social security funds) and state and local governments.

${ }^{5}$ Including currency and maturity composition.

${ }^{6}$ Daily (D), Weekly (W), Monthly (M), Quarterly (Q), Annually (A), Irregular (I); Not Available (NA).

${ }^{7}$ Reflects the assessment provided in the data ROSC published on December 8, 2005, and based on the findings of the mission that took place during January 11-26, 2005) for the dataset corresponding to the variable in each row. The assessment indicates whether international standards concerning concepts and definitions, scope, classification/sectorization, and basis for recording are fully observed (O), largely observed (LO), largely not observed (LNO), or not observed (NO).

${ }^{8}$ Same as footnote 7 , except referring to international standards concerning source data, statistical techniques, assessment and validation of source data, assessment and validation of intermediate data and statistical outputs, and revision studies. 


\section{NiCARAGUA: DebT SUSTAINABILITY ANALYSIS ${ }^{1,2}$}

While Nicaragua's debt burden has been substantially reduced thanks to the HIPC initiative, debt levels remain elevated and subject to a moderate risk of distress. Maintaining this riskclassification will be contingent on the continued reduction of the high level of domestic debt and the realization of the growth prospects assumed in this analysis. Long-term debt sustainability will continue to require the support of sound macroeconomic policies, including pursued fiscal consolidation. Full delivery of expected HIPC debt relief is key to reduce the risk of debt distress. The MDRI will contribute to lower debt-related vulnerability.

1. Nicaragua has made substantial progress in reducing its external debt burden in the context of the HIPC initiative (Table 1 and Figure 1). Since reaching completion point in January 2004, Nicaragua signed debt relief agreements with almost all its multilateral and all its ParisClub creditors, as well as a number of nonParis Club creditors. As of end-October 2005, total relief already committed amounted to US\$ 3.8 billion in nominal terms (76 percent of GDP). ${ }^{3}$

\section{Nevertheless, negotiations have} proven to be protracted with a number of creditors. Negotiations have stalled with several of Nicaragua's major non-Paris Club creditors, but some progress was made in recent months in the negotiations with private creditors. Nicaragua retained in January 2005 the services of financial and legal advisors, and several meetings have subsequently taken place between the creditors and Nicaragua and/or its advisors, with the aim of reconciling the amounts of debt outstanding and agree on

\footnotetext{
${ }^{1}$ Prepared jointly by IMF and World Bank staff.

2 This analysis focuses here on public debt only as comprehensive and reliable data on private external debt is not available. An indication of the possible magnitude of private external debt can be gleaned from BIS data. As of end-June 2004, this shows reporting banks' claims on the private sector in Nicaragua amounting to US\$ 244 million (5.4 percent of GDP).

${ }^{3}$ Including debt relief delivered under traditional mechanisms and additional debt relief beyond HIPC.
} 
the terms of debt reduction. The goal is to proceed with a buyback operation, financed by the World Bank's Debt Reduction Facility (DRF). As of October 2005, around US\$ 0.9 billion in NPV terms (18 percent of GDP) of HIPC debt relief was still uncommitted. Its delivery, assumed in this analysis, is key to reduce current vulnerabilities.

Table 1. Delivery of Expected HIPC Relief

\begin{tabular}{|c|c|c|c|c|c|c|c|}
\hline & \multirow{3}{*}{$\begin{array}{c}\text { HIPC debt relief } \\
\text { expected at } \\
\text { completion } \\
\text { point } \\
\mathrm{NPV}^{2 /}\end{array}$} & \multirow{2}{*}{\multicolumn{2}{|c|}{$\begin{array}{l}\text { HIPC debt relief } \\
\text { delivered } \\
\text { 31-Oct-05 }\end{array}$}} & \multirow{2}{*}{\multicolumn{2}{|c|}{$\begin{array}{l}\text { HIPC Debt relief still } \\
\text { expected }\end{array}$}} & \multirow{3}{*}{$\begin{array}{l}\text { Other debt } \\
\text { relief } \\
\text { received }\end{array}$} & \multirow{3}{*}{$\begin{array}{c}\begin{array}{c}\text { Total debt } \\
\text { relief } \\
\text { received }\end{array} \\
\mathrm{NPV}^{2 /}\end{array}$} \\
\hline & & & & & & & \\
\hline & & $\mathrm{NPV}^{2 /}$ & $\begin{array}{c}\text { In percent of } \\
\text { expected } \\
\text { relief }\end{array}$ & $\mathrm{NPV}^{2 /}$ & $\begin{array}{c}\text { In percent of } \\
\text { expected } \\
\text { relief }\end{array}$ & & \\
\hline Total & 3,308 & 2,433 & 74 & 876 & 26 & 730 & 3,162 \\
\hline Multilateral creditors & 1,134 & 1,124 & 99 & 10 & 1 & - & 1,124 \\
\hline Bilateral, Paris Club & 836 & 836 & 100 & - & - & 403 & 1,239 \\
\hline $\begin{array}{l}\text { Bilateral Non-Paris Club } \\
\text { and Private Creditors }\end{array}$ & 1,339 & 473 & 35 & 866 & 65 & 327 & 799 \\
\hline
\end{tabular}

Source: BCN and Fund staff estimates.

1/ Includes debt relief delivered under traditional mechanisms, and additional debt relief (beyond HIPC).

2/ NPV as of December 31, 1999.

3. Domestic public debt increased in 2000-01 in the context of a banking crisis and the settlement of claims arising from the expropriation of property, but has since fallen with the pursuit of fiscal consolidation. As of end-2004, it amounted to about 30 percent of GDP. At this point, more than $2 / 3$ of the domestic debt comprises property indemnization bonds (BPIs), issued by the government to resolve land disputes arising from expropriation of property under the former Sandinista regime. Most of the rest comprises central bank paper, issued on behalf of the government, to recapitalize intervened banks during the financial crisis of the early 2000's. About 4/5 of the stock of bonds at end-2004 had a remaining maturity of longer than one year. Domestic debt has fallen since 2003 in the context of shrinking fiscal deficits and substantial net external financing that has facilitated a substitution of domestic market debt with concessional external debt. This has also led to a reduction in the net present value of total debt. However, gross financing requirements on domestic debt in the next few years are expected to remain large, reflecting upcoming maturities of BPIs, highlighting the need for cautious liquidity management and moving forward with the fiscal consolidation effort. 


\section{Baseline scenario}

4. The baseline scenario for the debt sustainability analysis assumes that sound policies sustain improving macroeconomic conditions over the medium-term. ${ }^{4}$ In such a scenario, consistent with the authorities' PRSP, investment in human capital and infrastructure, financial sector development, and governance improvements boost total factor productivity, allowing a rate of GDP growth of about 5 percent per year. As the impact of the current oil shock is assumed to wane, inflation gradually decreases to around 3 percent annually. Fiscal consolidation is pursued: a primary surplus is achieved by 2007 and maintained thereafter. The current account improves gradually as exports benefit from continued investment in the tradable sector and rising volumes of traditional exports, while tourism activity converges to regional levels. Foreign direct investment is boosted by CAFTA-DR and the improvement in business conditions. Despite a gradual reduction in official financing to very small amounts, the coverage of net international reserves is expected to improve and reach about 4 months of imports by the end of the projection period.

\section{CAFTA-DR is expected to enhance the growth performance of the whole}

Central American region including Nicaragua. The main effects are likely to be a rapid increase in trade flows with the United States, increased diversification of production by the traded sector, a pickup in FDI inflows, and reduced macroeconomic volatility. Of all the signatory countries, Nicaragua is expected to face the smallest fiscal impact, mainly owing to a favorable schedule of tariff reductions. Sustained structural reforms, including further strengthening of the business environment and regulatory framework, would help Nicaragua leverage the full benefits of the agreement. ${ }^{5}$

\section{The debt-burden thresholds used for the analysis are those applying to strong} performers in terms of policies and institution quality, as measured by the World Bank's Country Policy and Institutional Assessment Index (CPIA). However, Nicaragua was only recently reclassified into this stronger category, and that by a narrow margin. ${ }^{6}$ In this context, debt indicators close to the thresholds reflect a vulnerable situation.

\footnotetext{
${ }^{4}$ The baseline scenario does not consider the implementation of the MDRI. The impact of this initiative is discussed in paragraph 10.

${ }^{5}$ The implications of CAFTA-DR for Nicaragua are discussed in Chapter 1 of the accompanying Selected Issues.

${ }^{6}$ In 2003, Nicaragua was classified a medium performer.
} 
Table 2. External Debt Burden Indicators

\begin{tabular}{|c|c|c|c|c|}
\hline & \multirow{2}{*}{ Thresholds } & \multicolumn{3}{|c|}{ Nicaragua's ratios } \\
\hline & & 2005 & 2015 & 2025 \\
\hline \multicolumn{5}{|c|}{ NPV of debt in percent of: } \\
\hline GDP & 50 & 40 & 49 & 22 \\
\hline Exports & 200 & 107 & 93 & 37 \\
\hline Revenues & 300 & 152 & 182 & 89 \\
\hline \multicolumn{5}{|c|}{ Debt service in percent: } \\
\hline Exports & 25 & 5 & 8 & 5 \\
\hline Revenues & 35 & 11 & 24 & 17 \\
\hline
\end{tabular}

Source: BCN and staff's estimates

1/ Based on Nicaragua's 2004 classification as a strong performer.

7. Under the favorable performance of the baseline scenario, Nicaragua's external public debt would still be high and remain a source of vulnerability for the next decade or so, before falling well below the thresholds (Table 3). Even assuming full delivery of HIPC relief by all creditors by end-2006, the net present value (NPV) of external public debt would increase from 40 percent of GDP in 2005 to 53 percent of GDP in 2011, reflecting continued heavy reliance on external financing of the public investment program. External debt would only decrease below the 50 percent threshold after 2014. Debt as a share of exports, however, would remain below the thresholds for the whole projection period, reflecting the relative openness of Nicaragua's economy. ${ }^{7}$ During the projection period, the external debt service-to-export ratio would also remain well below thresholds owing to the relative front loading of HIPC relief and the long grace periods granted by multilateral creditors.

8. Total public debt would show a similar path (Table 5). Under the baseline scenario, fiscal consolidation would facilitate continuing the process of substituting expensive domestic debt for external concessional debt for some time. Consequently, domestic debt would continue to decline gradually. As such, given the high proportion of external debt, the overall debt dynamics are dominated by developments of external debt.

\section{Sensitivity analysis}

9. Even though the baseline scenario points to Nicaragua's risk of debt distress being reduced over time, the debt still remains vulnerable to shocks. Stress tests illustrate the vulnerability of Nicaragua's debt situation. Under the standardized bound tests provided by the LIC-DSA external template, which simulate the impact on the baseline scenario of a series of shocks to real GDP growth, export growth, GDP deflator, the amount of transfers and FDI, and exchange rate, the external debt-to-GDP ratio increases rapidly above

\footnotetext{
${ }^{7}$ Even measuring exports net of maquila imports (the completion point methodology), debtto-export ratios would remain below the 200 percent threshold.
} 
70 percent (Table 4). In the most extreme stress test, the external debt ratio would not come back below the 50 percent threshold before 2021. In that scenario, total public debt would increase dramatically to over 90 percent and remain above 70 percent of GDP until 2015, even assuming that the fiscal consolidation effort is maintained through time (Table 6).

\section{The implementation of the Multilateral Debt Relief Initiative (MDRI) would} help reduce Nicaragua debt's vulnerability. The initiative would provide debt relief to Nicaragua equivalent to about 8 percent of GDP, of which 2 percent for the Fund and 6 percent for the Bank. ${ }^{8}$ With the implementation of the MDRI, all indicators of external debt sustainability would remain below thresholds for the whole projection period. The savings on debt service should be used to increase poverty reducing spending without generating any new debt burden. The dynamics of the external debt are mirrored by total public debt, given that the MDRI does not have an effect on domestic debt.

\section{Conclusion}

11. Nicaragua's debt is subject to a moderate risk of distress, but can be managed with the support of sound macroeconomic policies. Nicaragua's risk classification will remain contingent on the materialization of the growth prospects expected in the baseline scenario and on the sustained quality of economic policies and institutions. While most ratios remain below their thresholds in the baseline scenario, the threshold is breached in the case of the external-debt-to-GDP ratio for several years. In addition, the high level of domestic debt, if not successfully reduced, could pose a significant risk of debt distress in the medium term. While full delivery of expected debt relief is essential to lowering debt stocks, and delivery of relief under the MDRI would further reduce risks, reducing the probability of debt distress in the medium and long-term will continue to require sound macroeconomic policies, among which fiscal discipline is key.

12. The authorities broadly shared staff's assessment. Their own DSA is in line with staff's results. They agree that careful macroeconomic management is needed to ensure longterm debt sustainability, as recognized in the PRSP. The authorities also stressed that they have one of the largest share of non-multilateral non-Paris Club debt in their total debt among all HIPCs, and that this explains why progress in achieving the reduction of their debt expected at completion point has been slower. Finally, the authorities welcomed the MDRI and looked forward to benefiting from it as early as possible.

\footnotetext{
${ }^{8}$ Assuming a cancellation in January and July 2006 by the Fund and IDA respectively of all debt outstanding and disbursed as of end-2004 for the Fund and end-2003 for IDA.
} 


\section{Box 1. Change in the NPV of Debt-to-Exports Ratio from Completion Point}

Nicaragua reached the completion point under the HIPC Initiative with a projected NPV-of-debt-toexports ratio of 168 percent at end-2004. Using the methodology of the Low Income Countries DSA framework (DSF), this ratio as of end-2004 is now estimated at 110 percent, 58 percentage points lower. This decrease is mainly explained by the changes in methodology, but also in part by unanticipated changes in the variables used to calculate the ratio. The factors underlying the decrease in the ratio are the following:

1. Changes in methodology. The bulk of the decrease in the NPV-of-debt-to-exports ratio (53 percent) is explained by the change in the methodology used to calculate Nicaragua's debt indicators, including changes in:

a. The definition of exports: The DSF methodology uses a gross definition of the maquila sector, while the completion point definition included maquila exports net of imports. In addition, the DSF uses same-year exports, as opposed to the 3-year backward average used for the completion point.

b. The discount rate used to calculate the NPV of debt: the DSF methodology uses of a fixed 5 percent rate compared to the currency-specific discount rates under the HIPC methodology.

c. Exchange rates: Debt service is projected using WEO assumptions in the DSF, as opposed to fixed (end-2002) exchanges rates used for the completion point.

2. Unanticipated changes in the variables used for the projection, including stronger-thananticipated export performance and slightly higher-than-anticipated new disbursements.

Factors Undelying Changes in NPV of Debt-to-Exports Ratio After the Completion Point

\begin{tabular}{lrr}
\hline & $\begin{array}{r}\text { Percentage } \\
\text { Points }\end{array}$ & $\begin{array}{r}\text { Percent of } \\
\text { Total }\end{array}$ \\
\hline Projected NPV of debt-to-exports ratio (HIPC methodology) 1/ & 168.1 \\
Actual NPV of debt-to-annual exports ratio (LIC DSA Framework) 2/ & 110.0 \\
Total change & -58.1 & $100 \%$ \\
Due to change in methodology & -53.1 & $91 \%$ \\
1. From CIRR to 5\% discount rate & -3.5 & $6 \%$ \\
2. From fixed exchange rate to WEO projections & 6.8 & $-12 \%$ \\
3. From net to gross maquila exports & -34.2 & $59 \%$ \\
4. From three-year average to same-year exports & -22.3 & $38 \%$ \\
Due to unanticipated changes & -5.0 & $9 \%$ \\
4. Higher exports & -14.4 & $25 \%$ \\
5. New Borrowing & 0.4 & $-1 \%$ \\
Of which: Higher-than-anticipated disbursements & 0.6 & -0.2 \\
$\quad$ Higher-than-anticipated grant element & 9.0 & $-15 \%$ \\
6. Other factors 3/ & &
\end{tabular}

Source: Staff estimates.

1/ NPV of debt-to-exports ratio under assumption of full delivery of HIPC assistance.

2/ See "Operational Framework for Debt Sustainability Assessments in Low-Income Countries - Further Considerations", April 2005.

3/ Other factors capture non-delivery of HIPC assistance as estimated in the completion point or changes in the time and profile of assistance. 
Table 3. Nicaragua: External Debt Sustainability Framework, Baseline Scenario, 2002-25 1/ (In percent of GDP, unless otherwise indicated)

\begin{tabular}{|c|c|c|c|c|c|c|c|c|c|c|c|c|c|c|c|}
\hline & \multicolumn{3}{|c|}{ Actual } & \multirow{2}{*}{$\begin{array}{l}\text { Historical } \\
\text { Average 6/ }\end{array}$} & \multirow{2}{*}{$\begin{array}{c}\text { Standard } \\
\text { Deviation 6/ }\end{array}$} & \multirow{2}{*}{$\begin{array}{r}\text { Estimate } \\
2005 \\
\end{array}$} & \multicolumn{8}{|c|}{ Projections } & \multirow[b]{2}{*}{$\begin{array}{l}2011 . \\
\text { Aver: }\end{array}$} \\
\hline & 2002 & 2003 & 2004 & & & & 2006 & 2007 & 2008 & 2009 & 2010 & $\begin{array}{l}2005-10 \\
\text { Average }\end{array}$ & 2015 & 2025 & \\
\hline External debt (nominal) 1/ & 176.5 & 179.1 & 63.3 & & & 61.3 & 63.4 & 65.9 & 68.3 & 70.2 & 71.3 & & 62.8 & 27.3 & \\
\hline Change in external debt & 5.1 & 2.6 & -115.8 & & & -1.9 & 2.1 & 2.5 & 2.5 & 1.8 & 1.1 & & -2.7 & -3.5 & \\
\hline Non-interest current account deficit and official transfers & 12.0 & 10.3 & 8.7 & 12.1 & 2.9 & 9.8 & 9.5 & 9.0 & 8.3 & 7.8 & 7.3 & & 5.8 & 3.6 & \\
\hline Deficit in balance of goods and services & 25.6 & 26.0 & 26.3 & & & 29.9 & 30.1 & 29.1 & 28.2 & 27.5 & 26.6 & & 21.6 & 11.6 & \\
\hline Exports & 28.4 & 31.5 & 36.3 & & & 37.4 & 39.6 & 41.7 & 43.9 & 45.9 & 48.1 & & 52.4 & 61.0 & \\
\hline Imports & 54.0 & 57.5 & 62.6 & & & 67.3 & 69.7 & 70.8 & 72.1 & 73.4 & 74.7 & & 74.0 & 72.6 & \\
\hline Net current and capital transfers (negative $=$ inflow) & -17.7 & -19.4 & -21.2 & -16.8 & 4.1 & -21.4 & -21.7 & -21.4 & -21.2 & -20.9 & -20.6 & & -16.5 & -8.3 & \\
\hline $\mathrm{o} / \mathrm{w}$ official & -6.2 & -6.9 & -6.7 & & & -6.2 & -6.0 & -5.8 & -5.6 & -5.4 & -5.1 & & -3.6 & -0.5 & \\
\hline Net FDI (negative $=$ inflow) & -5.8 & -5.6 & -5.8 & -5.5 & 2.5 & -4.6 & -5.4 & -5.9 & -6.2 & -6.4 & -6.6 & & -6.8 & -7.3 & \\
\hline Endogenous debt dynamics $2 /$ & 4.2 & -4.4 & -15.5 & & & -1.4 & -0.9 & -1.4 & -1.6 & -1.9 & -2.0 & & -1.7 & -0.8 & \\
\hline Contribution from nominal interest rate & 0.9 & 0.8 & 0.6 & & & 0.9 & 1.2 & 1.3 & 1.4 & 1.3 & 1.3 & & 1.3 & 0.7 & \\
\hline Contribution from real GDP growth & -1.3 & -3.9 & -8.4 & & & -2.3 & -2.1 & -2.6 & -2.9 & -3.1 & -3.4 & & -3.1 & -1.4 & \\
\hline Contribution from price and exchange rate changes & 4.6 & -1.3 & -7.7 & & & & & & & & $\ldots$ & & & & \\
\hline Residual (3-4) 3/ & -5.3 & 2.3 & -103.3 & & & -5.7 & -1.0 & 0.7 & 1.9 & 2.3 & 2.4 & & 0.0 & 0.9 & \\
\hline $\mathrm{o} / \mathrm{w}$ exceptional financing & -16.6 & -5.7 & -36.2 & & & -28.3 & 0.0 & 0.0 & 0.0 & 0.0 & 0.0 & & 0.0 & 0.0 & \\
\hline NPV of PPG external debt & ... & ... & 40.0 & & & 40.0 & 42.1 & 44.8 & 47.5 & 49.9 & 51.7 & & 48.6 & 22.4 & \\
\hline In percent of exports & & & 110.3 & & & 106.9 & 106.3 & 107.6 & 108.3 & 108.7 & 107.6 & & 92.7 & 36.8 & \\
\hline PPG debt service-to-exports ratio (in percent) & 13.8 & 7.5 & 4.6 & & & 5.1 & 6.0 & 5.7 & 5.8 & 5.1 & 5.5 & & 7.6 & 5.4 & \\
\hline Total gross financing need (billions of U.S. dollars) & 405.3 & 293.9 & 211.5 & & & 356.0 & 346.7 & 304.1 & 267.7 & 227.6 & 211.5 & & 258.2 & -57.8 & \\
\hline \multicolumn{16}{|l|}{ Key macroeconomic assumptions } \\
\hline Real GDP growth (in percent) & 0.8 & 2.3 & 5.1 & 4.2 & 1.9 & 4.0 & 3.7 & 4.3 & 4.6 & 4.8 & 5.0 & 4.4 & 5.0 & 5.0 & \\
\hline GDP deflator in US dollar terms (change in percent) & -2.6 & 0.8 & 4.5 & 0.2 & 2.3 & 5.6 & 3.1 & 0.0 & -0.9 & -0.5 & -0.5 & 1.1 & 1.5 & 1.5 & \\
\hline Effective interest rate (percent) $5 /$ & 0.5 & 0.5 & 0.4 & 0.9 & 0.5 & 1.6 & 2.1 & 2.1 & 2.1 & 1.9 & 2.0 & 2.0 & 2.2 & 2.3 & \\
\hline Growth of exports of G\&S (US dollar terms, in percent) & 2.1 & 14.4 & 26.4 & 13.5 & 11.9 & 13.3 & 13.4 & 9.6 & 9.1 & 9.1 & 9.5 & 10.7 & 8.3 & 8.1 & \\
\hline Growth of imports of G\&S (US dollar terms, in percent) & 0.7 & 9.8 & 19.6 & 11.7 & 9.9 & 18.2 & 10.8 & 5.9 & 5.6 & 6.1 & 6.4 & 8.8 & 6.4 & 6.4 & \\
\hline Grant element of new public sector borrowing (in percent) & $\ldots$ & $\ldots$ & $\ldots$ & $\ldots$ & $\ldots$ & 25.8 & 27.5 & 22.9 & 22.4 & 22.4 & 22.6 & 23.9 & 21.9 & 14.3 & \\
\hline \multicolumn{16}{|l|}{ Memorandum item: } \\
\hline Nominal GDP (billions of US dollars) & 4025 & 4147 & 4556 & & & 5008 & 5358 & 5587 & 5789 & 6037 & 6308 & & 8541 & 16123 & \\
\hline
\end{tabular}

$1 /$ Includes only public sector external debt.

2/ Derived as $[\mathrm{r}-\mathrm{g}-\rho(1+\mathrm{g})](1+\mathrm{g}+\rho+\mathrm{g} \rho)$ times previous period debt ratio, with $\mathrm{r}=$ nominal interest rate; $\mathrm{g}=$ real GDP growth rate, and $\rho=$ growth rate of GDP deflator in U.S. dollar terms

3/ Includes exceptional financing (i.e., changes in arrears and debt relief); changes in gross foreign assets; and valuation adjustments. For projections also includes contribution from price and exchange rate changes.

4/ Assumes that NPV of private sector debt is equivalent to its face value.
5/Current-year interest payments devided by previous period debt stock.

6/ Historical averages and standard deviations are generally derived over the past 10 years, subject to data availability. 
Table 4. Nicaragua: Sensitivity Analyses for Key Indicators of Public and Publicly Guaranteed External Debt, 2005-25 (In percent)

\begin{tabular}{|c|c|c|c|c|c|c|c|c|}
\hline & \multirow{2}{*}{$\begin{array}{r}\text { Estimate } \\
2005\end{array}$} & \multicolumn{7}{|c|}{ Projections } \\
\hline & & 2006 & 2007 & 2008 & 2009 & 2010 & 2015 & 2025 \\
\hline \multicolumn{9}{|c|}{ NPV of debt-to-GDP ratio } \\
\hline Baseline & 40 & 42 & 45 & 47 & 50 & 52 & 49 & 22 \\
\hline \multicolumn{9}{|l|}{ A. Alternative Scenarios } \\
\hline A1. New public sector loans on less favorable terms in 2006-25 1/ & 40 & 44 & 47 & 51 & 55 & 57 & 58 & 34 \\
\hline \multicolumn{9}{|l|}{ B. Bound Tests } \\
\hline B1. Real GDP growth at historical average minus one standard deviation in 2006-07 & 40 & 43 & 46 & 49 & 52 & 53 & 50 & 23 \\
\hline B2. Export value growth at historical average minus one standard deviation in 2006-07 2/ & 40 & 45 & 54 & 57 & 59 & 61 & 54 & 23 \\
\hline B3. US dollar GDP deflator at historical average minus one standard deviation in 2006-07 & 40 & 44 & 48 & 51 & 54 & 56 & 52 & 24 \\
\hline B4. Net non-debt creating flows at historical average minus one standard deviation in 2006-073/ & 40 & 51 & 62 & 65 & 68 & 69 & 59 & 24 \\
\hline B5. Combination of B1-B4 using one-half standard deviation shocks & 40 & 52 & 65 & 68 & 70 & 72 & 62 & 25 \\
\hline B6. One-time 30 percent nominal depreciation relative to the baseline in 20064 / & 40 & 59 & 63 & 67 & 70 & 73 & 68 & 32 \\
\hline
\end{tabular}

\section{NPV of debt-to-exports ratio}

\section{Baseline}

$\begin{array}{rrrrrrrr}107 & 106 & 108 & 108 & 109 & 108 & \mathbf{9 3} & 37 \\ 107 & 110 & 114 & 117 & 119 & 119 & \mathbf{1 1 1} & 56\end{array}$

A. Alternative Scenarios
A1. New public sector loans on less favorable terms in 2006-25 1/

B. Bound Tests

B1. Real GDP growth at historical average minus one standard deviation in 2006-07

B2. Export value growth at historical average minus one standard deviation in 2006-07 2/

B3. US dollar GDP deflator at historical average minus one standard deviation in 2006-07

B4. Net non-debt creating flows at historical average minus one standard deviation in 2006-073/

B5. Combination of B1-B4 using one-half standard deviation shocks

B6. One-time 30 percent nominal depreciation relative to the baseline in 20064 /

$\begin{array}{llllllrl}107 & 106 & 108 & 108 & 109 & 108 & \mathbf{9 3} & 37 \\ 107 & 128 & 155 & 155 & 155 & 152 & \mathbf{1 2 5} & 45 \\ 107 & 106 & 108 & 108 & 109 & 108 & \mathbf{9 3} & 37 \\ 107 & 128 & 150 & 149 & 147 & 144 & \mathbf{1 1 3} & 39 \\ 107 & 132 & 157 & 156 & 154 & 151 & \mathbf{1 2 0} & 41 \\ 107 & 106 & 108 & 108 & 109 & 108 & \mathbf{9 3} & 37\end{array}$

\section{Debt service ratio}

\section{Baseline}

\section{A. Alternative Scenarios}

A1. New public sector loans on less favorable terms in 2006-25 1/

\section{B. Bound Tests}

B1. Real GDP growth at historical average minus one standard deviation in 2006-07

B2. Export value growth at historical average minus one standard deviation in 2006-07 2/

B3. US dollar GDP deflator at historical average minus one standard deviation in 2006-07

B4. Net non-debt creating flows at historical average minus one standard deviation in 2006-073/

B5. Combination of B1-B4 using one-half standard deviation shocks

B6. One-time 30 percent nominal depreciation relative to the baseline in 20064

Memorandum item:

Grant element assumed on residual financing (i.e., financing required above baseline) 6/

Source: Staff projections and simulations.

1/ Assumes that the interest rate on new borrowing is by 2 percentage points higher than in the baseline., while grace and maturity periods are the same as in the baseline.

2/ Exports values are assumed to remain permanently at the lower level, but the current account as a share of GDP is assumed to return to its baseline level after the shock (implicitly assuming an offsetting adjustment in import levels).

3/ Includes official and private transfers and FDI.

4/ Depreciation is defined as percentage decline in dollar/local currency rate, such that it never exceeds 100 percent.

5/ Applies to all stress scenarios except for A2 (less favorable financing) in which the terms on all new financing are as specified in footnote 1. 
Figure 2. Nicaragua: Indicators of Public and Publicly Guaranteed External Debt Under Alternative Scenarios, 2005-25

(In percent)

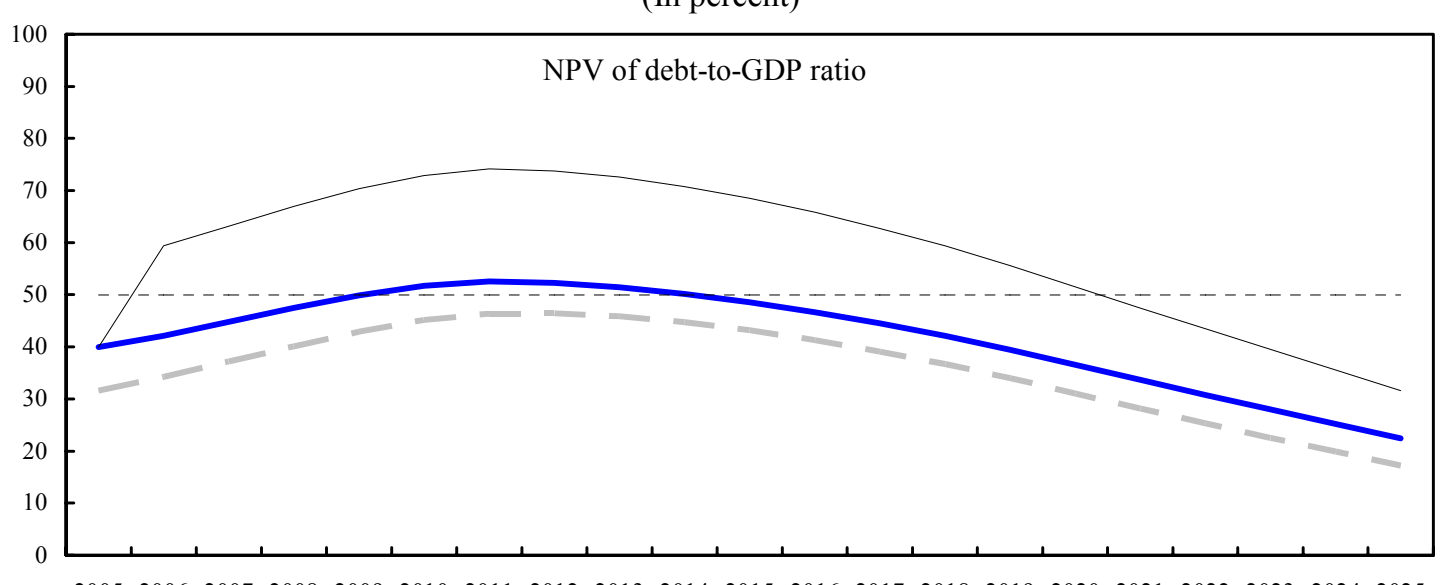

200520062007200820092010201120122013201420152016201720182019202020212022202320242025
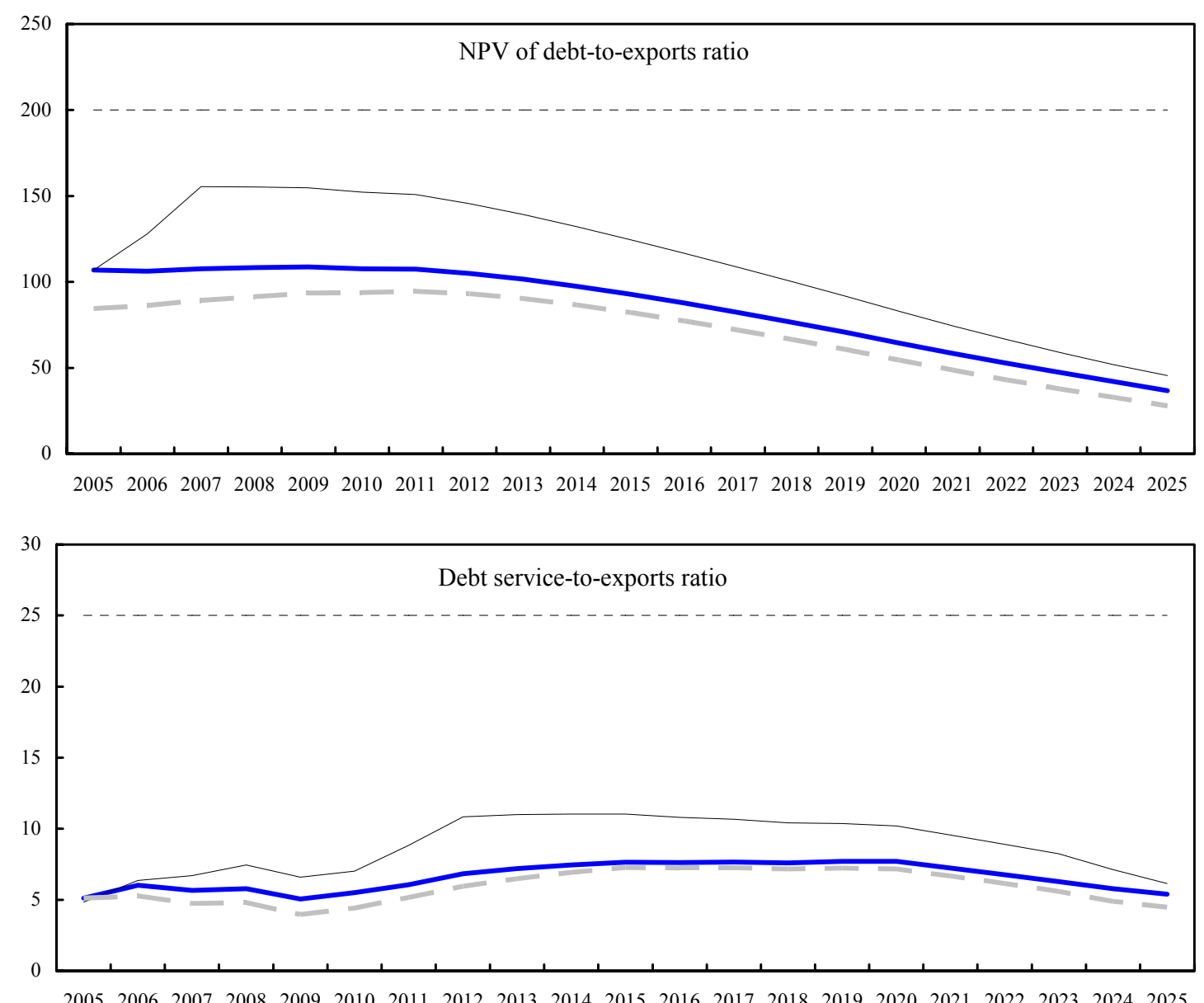

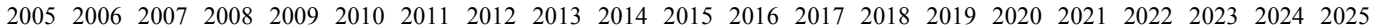

Baseline $\longrightarrow$ Most extreme stress test ---- Threshold $=$ With MDRI

Source: Staff projections and simulations. 
Table 5. Nicaragua: Public Sector Debt Sustainability Framework, Baseline Scenario, 2002-25

(In percent of GDP, unless otherwise indicated)

\begin{tabular}{|c|c|c|c|c|c|c|c|c|c|c|c|c|c|c|c|}
\hline & \multicolumn{3}{|c|}{ Actual } & \multirow[b]{2}{*}{$\begin{array}{l}\text { Historical } \\
\text { Average 5/ }\end{array}$} & \multirow[b]{2}{*}{$\begin{array}{l}\text { Standard } \\
\text { Deviation 5/ }\end{array}$} & \multicolumn{5}{|l|}{ Estimate } & \multicolumn{5}{|c|}{ Projections } \\
\hline & 2002 & 2003 & 2004 & & & 2005 & 2006 & 2007 & 2008 & 2009 & 2010 & $\begin{array}{l}2005-10 \\
\text { Average }\end{array}$ & 2015 & 2025 & $\begin{array}{l}2011-25 \\
\text { Average }\end{array}$ \\
\hline $\begin{array}{l}\text { Public sector debt } 1 / \\
\mathrm{o} / \mathrm{w} \text { foreign-currency denominated }\end{array}$ & $\begin{array}{l}197.7 \\
197.7\end{array}$ & $\begin{array}{l}213.4 \\
213.4\end{array}$ & $\begin{array}{l}92.7 \\
92.7\end{array}$ & & & $\begin{array}{l}87.6 \\
87.6\end{array}$ & $\begin{array}{l}82.7 \\
82.7\end{array}$ & $\begin{array}{l}80.9 \\
80.9\end{array}$ & $\begin{array}{l}80.3 \\
80.3\end{array}$ & $\begin{array}{l}79.2 \\
79.2\end{array}$ & $\begin{array}{l}78.1 \\
78.1\end{array}$ & & $\begin{array}{l}62.7 \\
61.8\end{array}$ & $\begin{array}{l}27.5 \\
27.3\end{array}$ & \\
\hline Change in public sector debt & 4.2 & 15.7 & -120.7 & & & -5.0 & -5.0 & -1.8 & -0.5 & -1.1 & -1.2 & & -2.9 & -3.5 & \\
\hline Identified debt-creating flows & 12.5 & -1.1 & -18.5 & & & -6.3 & -3.6 & -2.0 & -1.8 & -1.9 & -2.3 & & -4.6 & -3.2 & \\
\hline Primary deficit & 2.5 & 1.8 & 0.7 & 1.2 & 1.4 & 0.2 & 0.2 & -0.7 & -0.9 & -1.0 & -1.0 & -0.5 & -1.9 & -2.0 & -2.0 \\
\hline Revenue and grants & 22.4 & 24.2 & 26.4 & & & 26.8 & 27.0 & 27.1 & 27.1 & 27.0 & 27.0 & & 26.7 & 25.4 & \\
\hline of which: grants & 2.9 & 3.4 & 3.6 & & & 3.8 & 3.8 & 3.8 & 3.7 & 3.6 & 3.5 & & 2.7 & 0.5 & \\
\hline Primary (noninterest) expenditure & 25.0 & 26.0 & 27.0 & & & 27.0 & 27.2 & 26.4 & 26.2 & 26.1 & 26.0 & & 24.8 & 23.4 & \\
\hline Automatic debt dynamics & 10.4 & -2.6 & -17.8 & & & -6.2 & -3.7 & -1.3 & -1.0 & -0.9 & -1.3 & & -2.7 & -1.2 & \\
\hline Contribution from interest rate/growth differential & 1.0 & -5.6 & -10.5 & & & -2.7 & -2.1 & -2.7 & -2.6 & -2.9 & -3.3 & & -3.0 & -1.4 & \\
\hline of which : contribution from average real interest rate & 2.5 & -1.3 & 0.0 & & & 0.9 & 1.1 & 0.7 & 1.0 & 0.8 & 0.5 & & 0.1 & 0.1 & \\
\hline of which: contribution from real GDP growth & -1.4 & -4.4 & -10.4 & & & -3.6 & -3.2 & -3.4 & -3.6 & -3.7 & -3.8 & & -3.1 & -1.5 & \\
\hline Contribution from real exchange rate depreciation & 9.4 & 3.0 & -7.3 & & & -3.6 & -1.6 & 1.4 & 1.6 & 2.0 & 2.0 & & $\ldots$ & $\ldots$ & \\
\hline Other identified debt-creating flows & -0.4 & -0.3 & -1.4 & & & -0.2 & -0.2 & 0.0 & 0.0 & 0.0 & 0.0 & & 0.0 & 0.0 & \\
\hline Privatization receipts (negative) & -0.4 & -0.3 & -1.4 & & & -0.2 & -0.2 & 0.0 & 0.0 & 0.0 & 0.0 & & 0.0 & 0.0 & \\
\hline Recognition of implicit or contingent liabilities & 0.0 & 0.0 & 0.0 & & & 0.0 & 0.0 & 0.0 & 0.0 & 0.0 & 0.0 & & 0.0 & 0.0 & \\
\hline Debt relief (HIPC and other) & 0.0 & 0.0 & 0.0 & & & 0.0 & 0.0 & 0.0 & 0.0 & 0.0 & 0.0 & & 0.0 & 0.0 & \\
\hline Other (specify, e.g. bank recapitalization) & 0.0 & 0.0 & 0.0 & & & 0.0 & 0.0 & 0.0 & 0.0 & 0.0 & 0.0 & & 0.0 & 0.0 & \\
\hline Residual, including asset changes & -8.3 & 16.7 & -102.2 & & & 1.3 & -1.4 & 0.2 & 1.3 & 0.7 & 1.1 & & 1.7 & -0.3 & \\
\hline NPV of public sector debt & 160.6 & 173.5 & 69.4 & & & 65.9 & 61.2 & 59.6 & 59.3 & 58.8 & 58.3 & & 48.4 & 22.5 & \\
\hline $\mathrm{o} / \mathrm{w}$ foreign-currency denominated & 160.6 & 173.5 & 69.4 & & & 65.9 & 61.2 & 59.6 & 59.3 & 58.8 & 58.3 & & 47.5 & 22.3 & \\
\hline $\mathrm{o} / \mathrm{w}$ external & 139.3 & 139.2 & 40.0 & & & 40.3 & 41.8 & 44.5 & 47.1 & 49.5 & 51.3 & & 48.4 & 22.5 & \\
\hline NPV of contingent liabilities (not included in public sector debt) & $\ldots$ & & $\ldots$ & & & $\ldots$ & $\ldots$ & & $\ldots$ & $\ldots$ & $\ldots$ & & $\ldots$ & $\ldots$ & \\
\hline Gross financing need $2 /$ & 11.9 & 10.3 & 14.7 & & & 3.2 & 6.8 & 4.9 & 4.7 & 4.5 & 4.0 & & 3.1 & 1.3 & \\
\hline $\mathrm{NPV}$ of public sector debt-to-revenue ratio (in percent) $3 /$ & 715.5 & 717.2 & 263.3 & & & 245.8 & 227.0 & 220.0 & 219.3 & 217.5 & 215.9 & & 180.9 & 88.9 & \\
\hline o/w external & 620.5 & 575.3 & 151.8 & & & 150.3 & 155.0 & 164.0 & 174.1 & 183.1 & 189.9 & & 180.9 & 88.9 & \\
\hline Debt service-to-revenue ratio (in percent) $3 / 4 /$ & 41.7 & 35.1 & 53.2 & & & 11.2 & 24.3 & 20.8 & 20.5 & 20.3 & 18.4 & & 19.0 & 13.0 & \\
\hline Primary deficit that stabilizes the debt-to-GDP ratio & -1.7 & -13.8 & 121.4 & & & 5.2 & 5.2 & 1.1 & -0.3 & 0.1 & 0.2 & & 1.0 & 1.5 & \\
\hline \multicolumn{16}{|l|}{ Key macroeconomic and fiscal assumptions } \\
\hline Real GDP growth (in percent) & 0.8 & 2.3 & 5.1 & 4.2 & 1.9 & 4.0 & 3.7 & 4.3 & 4.6 & 4.8 & 5.0 & 4.4 & 5.0 & 5.0 & 5.0 \\
\hline Average nominal interest rate on forex debt (in percent) & 0.0 & 0.0 & 1.1 & 0.1 & 0.4 & 2.5 & 2.5 & 2.6 & 3.4 & 3.1 & 2.8 & 2.8 & 2.2 & 2.4 & 2.4 \\
\hline Real exchange rate depreciation (in percent, + indicates depreciation) & 4.8 & 1.6 & -3.6 & 1.6 & 2.6 & -4.0 & -1.9 & 1.7 & 2.1 & 2.6 & 2.6 & 0.5 & 0.5 & 0.5 & 0.5 \\
\hline Inflation rate (GDP deflator, in percent) & 3.2 & 6.8 & 10.2 & 9.2 & 3.1 & 10.9 & 8.3 & 5.0 & 3.0 & 2.5 & 2.5 & 5.4 & 2.5 & 2.5 & 2.5 \\
\hline Growth of real primary spending (deflated by GDP deflator, in percent) & -3.6 & 6.7 & 9.2 & 6.4 & 10.8 & 3.7 & 4.7 & 1.1 & 3.9 & 4.2 & 4.9 & 3.8 & 4.2 & 4.5 & 4.2 \\
\hline Grant element of new external borrowing (in percent) & $\ldots$ & & 29.8 & 29.8 & 0.0 & 29.8 & 27.4 & 23.1 & 22.6 & 22.6 & 22.9 & 24.7 & 22.2 & 14.6 & \\
\hline
\end{tabular}

Sources: Country authorities; and Fund staff estimates and projections.

2/ Gross financing need is defined as the primary deficit plus debt service plus the stock of short-term debt at the end of the last period.

$3 /$ Revenues including grants.

/ Debt service is defined as the sum of interest and amortization of medium and long-term debt.

5 / Historical averages and standard deviations are generally derived over the past 10 years, subject to data availability. 


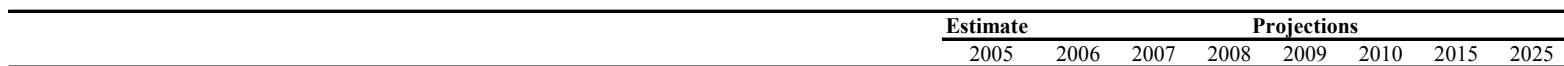

NPV of Debt-to-GDP Ratio

\section{Baseline}

\section{A. Alternative scenarios}

A1. Primary balance is unchanged from 2004

A2. Permanently lower GDP growth 1/

\section{B. Bound tests}

B1. Primary balance is at historical average minus one standard deviations in 2006-2007

B2. Combination of B1-B2 using one half standard deviation shocks

B3. One-time 30 percent real depreciation in 2006

B4. 10 percent of GDP increase in other debt-creating flows in 2006

$\begin{array}{llllllll}66 & 61 & 60 & 59 & 59 & 58 & 48 & 23 \\ & & & & & & & \\ 66 & 62 & 61 & 62 & 63 & 64 & 61 & 51 \\ 66 & 62 & 60 & 61 & 61 & 61 & 54 & 39 \\ & & & & & & & \\ 66 & 63 & 64 & 64 & 63 & 62 & 52 & 25 \\ 66 & 63 & 64 & 63 & 63 & 62 & 52 & 24 \\ 66 & 91 & 88 & 87 & 86 & 86 & 72 & 40 \\ 66 & 69 & 67 & 67 & 66 & 66 & 55 & 27\end{array}$

NPV of Debt-to-Revenue Ratio 2/

\section{Baseline}

A. Alternative scenarios

A1. Primary balance is unchanged from 2004

A2. Permanently lower GDP growth $1 /$

$\begin{array}{llllllll}246 & 227 & 220 & 219 & 218 & 216 & 181 & 89\end{array}$

\section{B. Bound tests}

B1. Primary balance is at historical average minus one standard deviations in 2006-2007

B2. Combination of B1-B2 using one half standard deviation shocks

B3. One-time 30 percent real depreciation in 2006

B4. 10 percent of GDP increase in other debt-creating flows in 2006

\section{Debt Service-to-Revenue Ratio 2/}

\section{Baseline}

\section{A. Alternative scenarios}

A1. Primary balance is unchanged from 2004

A2. Permanently lower GDP growth $1 /$

$\begin{array}{rrrrrrrr}246 & 234 & 236 & 235 & 233 & 231 & 194 & 98 \\ 246 & 233 & 235 & 234 & 232 & 230 & 193 & 96 \\ 246 & 336 & 325 & 322 & 320 & 317 & 268 & 158 \\ 246 & 256 & 248 & 247 & 245 & 243 & 205 & 105\end{array}$

\section{B. Bound tests}

B1. Primary balance is at historical average minus one standard deviations in 2006-2007

B2. Combination of B1-B2 using one half standard deviation shocks

B3. One-time 30 percent real depreciation in 2006

B4. 10 percent of GDP increase in other debt-creating flows in 2006

Sources: Country authorities; and Fund staff estimates and projections.

1/ Assumes that real GDP growth is at baseline minus one standard deviation divided by the square root of 20 (i.e., the length of the projection period).

2/ Revenues are defined inclusive of grants. 
Figure 3. Nicaragua: Indicators of Public Debt Under Alternative Scenarios, 2005-25 1/

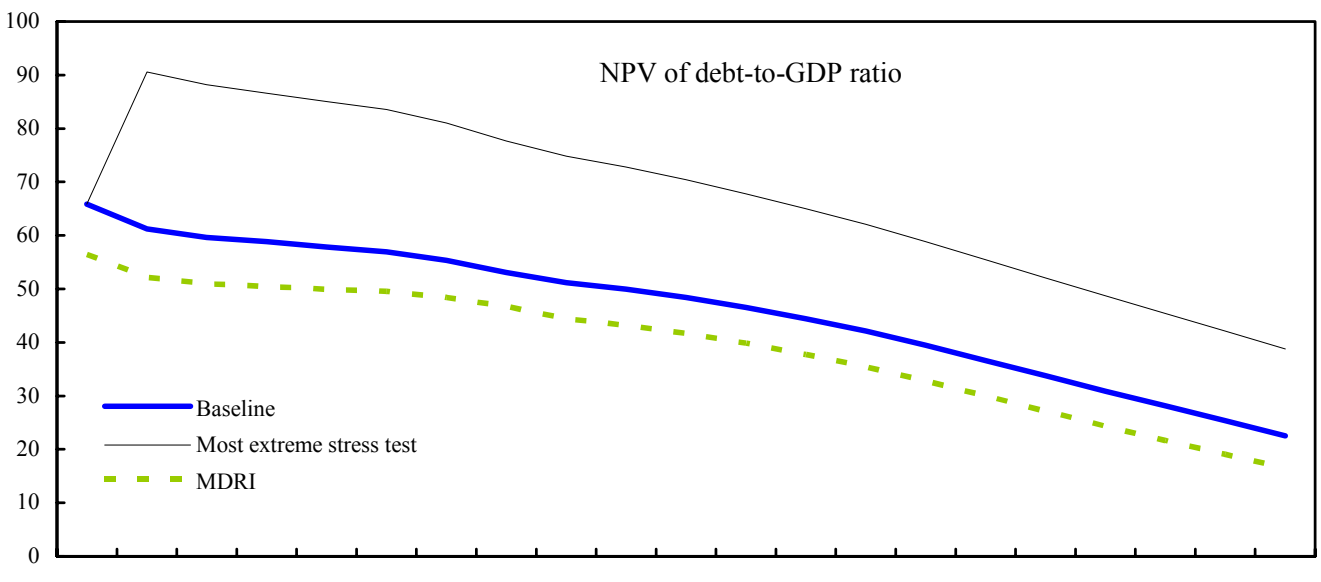

200520062007200820092010201120122013201420152016201720182019202020212022202320242025

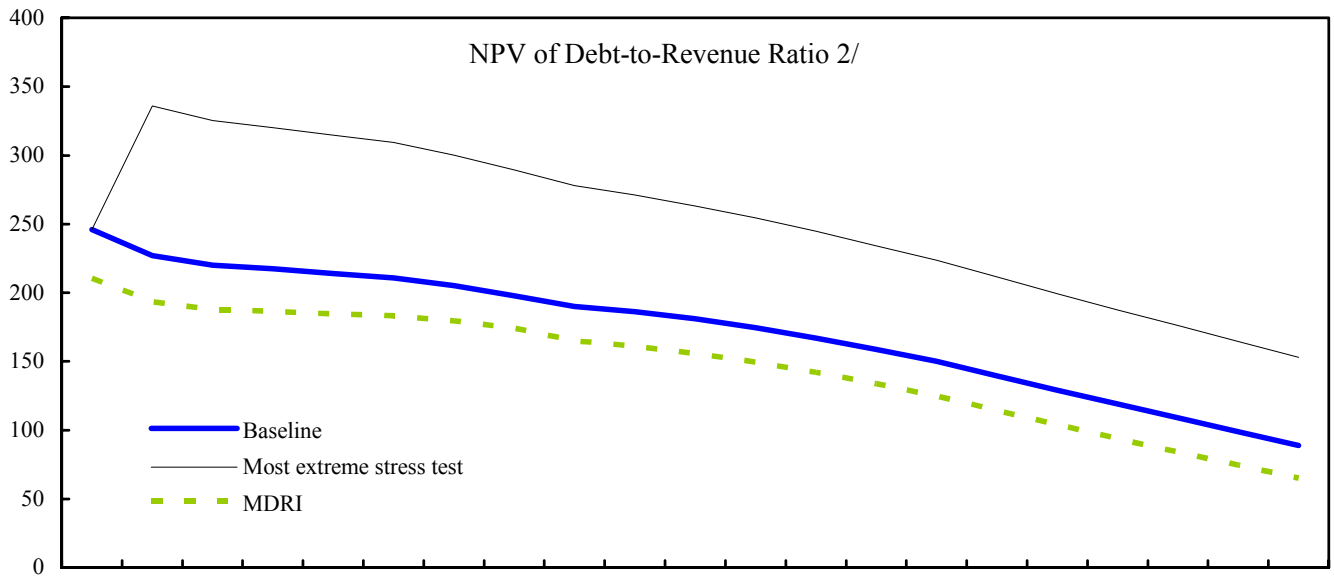

200520062007200820092010201120122013201420152016201720182019202020212022202320242025

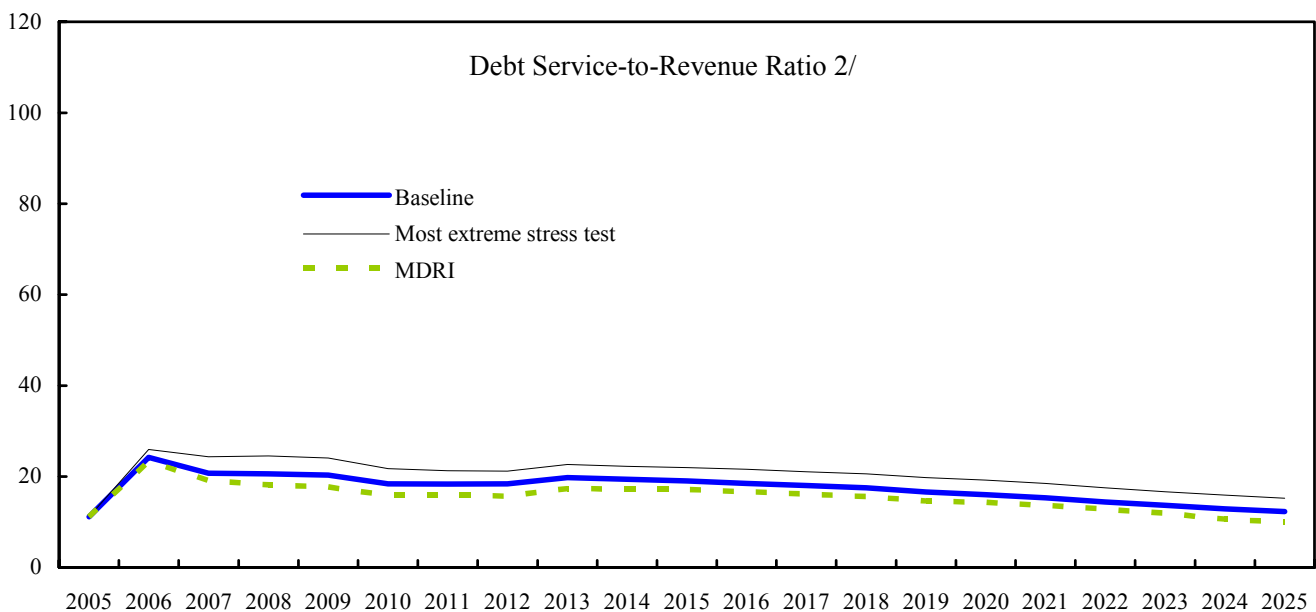

Source: Staff projections and simulations.

1/ Most extreme stress test is test that yields highest ratio in 2015.

2/ Revenue including grants. 
Managua, December 27, 2005

Mr. Rodrigo de Rato

Managing Director

International Monetary Fund

Washington, D.C. 20431

Dear Mr. de Rato:

We reaffirm our strong commitment to our poverty reduction strategy and the program supported by the Poverty Reduction and Growth Facility (PRGF). We would like to ask for a completion of the pending reviews under the program, and that the PRGF arrangement be extended through December 12, 2006. This will help support our macroeconomic policy framework in the run-up to the November 2006 elections. The attached Supplementary Memorandum of Economic and Financial Policies (SMEFP) outlines the economic policies and objectives of the Government of Nicaragua for the year 2006. Also attached is a Technical Memorandum of Understanding (TMU).

Macroeconomic developments in 2004 were positive. Growth accelerated and inflation remained in single digits, while most key program quantitative targets were met. Nicaragua also reached the HIPC completion point in January 2004. The $5^{\text {th }}$ and $6^{\text {th }}$ reviews under the PRGF were completed in September 2004.

In 2005, Nicaragua's macroeconomic framework has been broadly stable, but has come under pressure. This reflects the substantial challenges presented by higher international oil prices, but also delays in the structural reform agenda. Combined with approval of a 2005 budget that widened the deficit relative to the executive's proposal and included significant public sector wage increases, this has prevented completion of program reviews in the past year. Accordingly, we have taken steps to strengthen the 2005 fiscal framework. In the context of a renewed national dialogue involving all political parties, we have also reinvigorated our structural reform agenda through the passage of several key laws. With these measures, we are confident that the economy will continue to grow, that inflation will gradually subside, and that the fiscal program will remain on track. New performance criteria are being established to help maintain stability, and set a roadmap for carrying the reform agenda forward.

We have continued to maintain a close policy dialogue with the Fund in the past year. With regards program performance in 2004 (no performance criteria have been established for 2005), we have met all quantitative performance criteria for end-June and end-September but missed the performance criteria on the central government overall balance (after grants) for end-December by a narrow margin. We have also been unable to submit a fiscal responsibility law to the National Assembly by October 15, 2004, but propose corrective 
action in the attached memorandum ( $₫ 12-13)$. We therefore, request waivers for nonobservance of these two performance criteria and the completion of the $7^{\text {th }}, 8^{\text {th }}$, and $9^{\text {th }}$ reviews under the program, rephasing of amounts committed, and an extension of the arrangement through December 12, 2006. To ensure continued good macroeconomic performance, the national assembly has approved a 2006 budget consistent with our PRGFsupported program.

We would like to take this opportunity to mention that even after reaching the HIPC completion point, Nicaragua's debt obligations remain large. Participation in the Multilateral Debt Reduction Initiative (MDRI) is very important for Nicaragua, as this additional relief would release resources for poverty reducing spending supporting our efforts to meet the Millennium Development Goals. We welcome this initiative and look forward to benefit from it at an early point.

The request for completion of the financing assurances review is based on satisfactory assurances of external financing evidenced by recent pledges of budget support by donors, and on our intent to use the IDA Debt Reduction Facility to resolve our outstanding obligations to commercial creditors. We are committed to continue good faith negotiations with all non-Paris Club official and private creditors to seek debt relief in line with the principle of equitable burden sharing among creditors under the enhanced HIPC Initiative.

We propose that the Fund carry out program reviews by June 2006 and September 2006, based on the observance, respectively, of end-March 2006, and end-June 2006 quantitative and structural performance criteria, as well as end-August structural performance criteria established in Tables 1 and 3 of the attached memorandum.

The government of Nicaragua remains fully committed to the implementation of the Fund supported program and is confident that the policies and measures set forth in the attached memorandum are adequate to achieve the program's objectives under the PRGF arrangement. Nevertheless, we stand ready to take, in consultation with Fund staff, any additional steps that may be needed to keep our program on track. Recognizing the need for transparency, we intend to publish the staff report and to continue to periodically inform the public on progress under the program through various channels.

Sincerely yours,

$/ \mathrm{s} /$

Mario B. Alonso I.

President, Central Bank of Nicaragua
$/ \mathrm{s} /$

Mario Arana S.

Minister of Finance 


\section{SUPPLEMENTARY MEMORANDUM OF ECONOMIC AND FINANCIAL POLICIES}

\section{The Macroeconomic Policy Framework}

1. Macroeconomic developments in 2004 were positive. Real GDP growth accelerated to 5.1 percent driven by a strong recovery in exports, higher commodity prices and booming remittances. Inflation remained in single digits. Nicaragua reached the HIPC completion point in January 2004, leading to external debt relief of about US\$ $4 \frac{1}{2}$ billions in NPV terms.

2. The macroeconomic framework in $\mathbf{2 0 0 5}$ has been broadly stable, but has come under pressure, reflecting in part the impact of higher oil prices. The economy is expanding but at a slower pace reflecting weaker external demand and higher oil prices. We expect real GDP growth in 2005 to moderate to 4 percent and believe this pace of growth would slow further to $3 \frac{3}{4}$ percent in 2006. Inflation is expected to reach $10 \frac{1}{2}$ percent $y / y$ at end2005 reflecting mainly higher oil prices. We are committed to fighting the second-round impact of these supply shocks and anticipate our policy efforts will

Nicaragua: Key Macroeconomic Objectives, 2004-2006 (annual percent change, unless otherwise indicated)

\begin{tabular}{lcrr}
\hline \multicolumn{4}{c}{ (annual percent change, unless otherwise indicated) } \\
& 2004 & 2005 & 2006 \\
& & Proj. & Proj. \\
\hline Real GDP growth & 5.1 & 4.0 & 3.7 \\
Inflation (eop) & 9.3 & 10.5 & 7.3 \\
Gross international reserves (US\$ millions) & 670 & 648 & 776 \\
Net international reserves (US\$ millions) & 211 & 226 & 311 \\
CPS balance after grants (in percent of GDP) & -2.8 & -2.2 & -2.2 \\
\hline Sources: Central Bank of Nicaragua; Ministry of Finance; and Fund staff estimates/projections
\end{tabular}
guide inflation down towards 71/4 percent by end-2006.

\section{Fiscal Policy}

3. We have taken steps to strengthen the fiscal policy framework following passage of the weakened 2005 budget late last year. The executive's proposal targeted a reduction in the CPS deficit relative to the expected 2004 outcome. However, the budget approved by the National Assembly implied instead a smaller adjustment, and included an increase in the total wage bill of some 21 percent. Most of this wage increase was received by health workers and teachers. Accordingly, we have implemented revenue measures expected to yield about $1 / 2$ percent of GDP on a full year basis to bring the fiscal program back on track. As a result, revenue growth this year has been strong, also reflecting continued improvements in tax administration and a surge in taxes on imports. Combined with higherthan-originally-budgeted foreign grants, this has facilitated approval of a revised budget increasing capital spending consistent with a projected CPS deficit of 2.2 percent of GDP in 2005.

\section{The 2006 budget approved by the National Assembly targets a CPS deficit (after} grants) of 2.2 percent of GDP, unchanged with respect to the estimate for 2005 . However, the underlying fiscal position would improve still further as the 2006 budget includes one-time costs of about 1 percent of GDP related to the national and regional elections. The underlying fiscal adjustment is consistent with our longstanding policy of steadily increasing domestic savings and reducing the high public debt. The budget envisages that tax revenues will be maintained at 17.6 percent of GDP. We remain committed to 
avoiding any increases in tax exemptions, and to lowering these over the medium term, to support our efforts in increasing poverty reduction spending. The budget prioritizes outlays in a manner that protects crucial spending on human and physical capital accumulation. As a result, despite additional one-time expenses on elections, we are maintaining povertyreducing spending at the 2005 level of 13.4 percent of GDP.

\section{The government sought in the $\mathbf{2 0 0 6}$ budget to hold the increase in the wage bill} to no more than expected inflation to protect poverty-reducing spending and

competitiveness. Total central government compensation in 2005 is approaching 7 percent of GDP and accounts for more than 1/3 of primary spending. Moreover, real public wages are increasing faster than in the private sector. We are concerned that continuation of rapid wage increases in the public sector will put pressures on private sector wages and ultimately on inflation and competitiveness. However, we are committed to preserving the fiscal space for poverty reducing programs. Hence, the budgetary wage bill has been increased by 9.7 percent $\mathrm{y} / \mathrm{y}$, slightly higher than expected 2006 inflation of 8.8 percent $\mathrm{y} / \mathrm{y}$. Indeed, in support of our efforts to control the wage bill the program is establishing a quantitative performance criterion on wage expenditures, comprising the bulk of the budgetary wage bill that can be readily monitored and directly controlled. ${ }^{22}$

6. We have begun increasing electricity rates to eliminate quasi-fiscal losses in the sector. Oil fuelled plants account for about 80 percent of electricity generated in Nicaragua, and the sector has been heavily affected by rising international petroleum prices. To begin the process of eliminating these losses, we have increased rates by about 20 percent between July and December 2005. We are committed to further price adjustments by June 2006 required in order to eliminate quasi-fiscal losses in the sector by December 2006. To support achieving these goals, the program includes a performance criterion on further increases in average tariff prices. In line with this, we have estimated that average tariff prices will need to be raised by an additional $6 \frac{1}{2}$ percent before June next year, to reach a level of 0.1588 US $\$ / \mathrm{KWh}$. We will review in coordination with the energy regulator, the need for action depending upon actual developments in real input costs. Moreover, we intend to introduce by June 2006 a mechanism for automatic adjustment of tariffs with fluctuations with real input costs to avoid a repetition of the recent crisis in the sector. We will continue the policy of targeted subsidies to protect low usage consumers from tariff increases.

\section{Monetary and Exchange rate policies}

\section{We are tightening monetary conditions to signal our determination to protect} reserves, support the crawling peg and help keep inflation under control. After overperforming in 2004, international reserves have been broadly in line with our 2005 monetary program despite delays in disbursements of external funds. However, we are concerned that

\footnotetext{
${ }^{22}$ See 99 of the attached Technical Memorandum of Understanding (TMU) for definitions of the wage bill that will be monitored under our program.
} 
the increase in inflation could reflect second-round effects of high oil prices and demand pressures that may negatively affect international reserves. Accordingly, in an early move, we started tightening monetary policy in November this year. Furthermore, we will continue supporting the monetary stance by increasing central government deposits at the central bank in 2006. As such, we are targeting a reduction in NDA of C\$974 million and an increase in NIR of US\$85 million in 2006.

8. Keeping the rate of crawl of the exchange rate peg unchanged at 5 percent in 2006 will appropriately balance stability and competitiveness. In recent years, a key objective of our program has been to gradually slow the rate of crawl to help to reduce inflation, reflecting the high pass through of the exchange rate to prices. However, given election related uncertainties, keeping the rate of crawl unchanged in 2006 will buffer shocks and will help protect competitiveness.

\section{Structural policies}

\section{We are committed to further strengthening the fiscal framework including by} reducing budget rigidities, which are creating significant problems for fiscal management. Significant earmarking of public spending is a key source of pressure on the budget, crowding out poverty reducing spending, and distorting incentives. The government is constitutionally required to transfer 6 percent of expenditures to universities and 4 percent of expenditures to the judiciary. Combined with transfers to municipalities within the current decentralization framework, they hamper fiscal management. We will seek to raise public awareness of these constraints, and their implications for sustaining poverty reducing spending, as we develop our plans to strengthen the fiscal framework that are outlined in the next paragraphs.

10. The government remains committed to achieving effective decentralization. It has proven difficult to match devolved revenues and expenditures across municipalities. Under the current legal framework, revenue transfers to municipalities are not linked to expenditure responsibilities. As such, achieving effective decentralization will require changing the municipal transfer law, the municipality law and other related laws. To accomplish this, we have reached an understanding with the political parties to amend the municipal transfer and municipality laws next year, to devolve expenditure responsibilities to municipalities in line with revenues transferred to them and make other associated changes to the overall decentralization framework. We are committed to these reforms and the program establishes as a structural benchmark that revisions of the concerned laws be submitted to the National Assembly by June 2006 ( $\mid 28$ of the TMU).

\section{We have taken measures to achieve some devolution in the $\mathbf{2 0 0 6}$ budget and} delay increases in transfers to municipalities. To achieve some devolution of spending responsibilities, and to protect fiscal neutrality, the 2006 budget cuts capital spending on municipalities by the equivalent of half of revenue transfers. To support implementation of this budgetary provision, we have also issued a decree that curtails central government spending in areas that are the responsibility of municipalities. The World Bank is providing 
technical assistance to design appropriate incentive systems to ensure that expenditures at the local level are consistent with national priorities. We are also working in partnership with decentralized agencies to use existing central government budget execution mechanisms to undertake projects on behalf of the municipalities. The 2006 budget maintains the transfers to municipalities at 6 percent of government's revenues and the assembly has amended the transfer law such that the previously legislated increase in transfers to 10 percent of government revenues in 2007 will be delayed. Instead, transfers will be increased to 7 percent of revenues in 2007, and another percentage point each year until reaching 10 percent of revenue in 2010 (however, transfers can be increased to 10 percent as soon as laws referred to in $\uparrow 10$ are passed consistent with the devolution of spending responsibilities corresponding to the envisaged rise in transfers).

\section{Passage of a fiscal responsibility law (FRL) has been delayed but we have} approved a financial administration law (FAL) to strengthen the budget framework. Approval of an FRL was a structural performance criterion for October 15, 2004. We prepared a preliminary draft FRL that aimed to facilitate a sustained improvement of the fiscal position, reduce the public debt, and increase transparency and accountability. However, international experience indicates that FRLs have typically been successful where they are accompanied by a national consensus on both their importance and their content. We believe that we will need more time to build such a consensus before submitting the FRL to the national assembly. Instead, we proceeded with the FAL that seeks to address concerns regarding the budget process and framework. It provides for: (i) strengthening the monitoring and control systems of the public sector; (ii) approval of all budgetary expenditures by the assembly (including any financed with concessional resources); (iii) more clearly identifying the roles of the ministry of finance and other government agencies in preparing the capital expenditure budget of the public sector; (iv) establishment of a consensus-building committee comprising representatives from the National Assembly and Ministry of Finance to assess the feasibility of financing intended increases in overall budgetary expenditures; and (v) placing time-limits on the assembly's review of the budget.

\section{Developing a road-map for moving in the direction of introducing an FRL and} strengthening further the FAL is crucial. As such, the program introduces a structural performance criterion on preparing a roadmap to strengthen the fiscal responsibility framework ( $₫ 29$ of the TMU) by August 2006, for consideration by the administration that would assume office in January 2007. Such a road-map should aim to facilitate a sustained improvement of the fiscal position, reduce the public debt, and increase transparency and accountability. The proposal will also seek to expand the coverage of the budget to the entire non-financial public sector and constrain the use of escape clauses to emergency situations only ( $\mid 29$ item 4 in the TMU). The road-map should include an evaluation of any constitutional amendments that may be needed to achieve these reforms and recommend a strategy moving forward.

14. Reforming the pension system is also a key policy priority. A thorough revision of the framework is needed to solve the actuarial insolvency of the current pay-as-you-go pension system, which will begin to incur significant cash deficits in the medium term. A 
high-level, presidentially-appointed commission had worked on a revised strategy for pension reform. Recognizing that our original reform strategy, of moving to a fully funded system, would have been prohibitively costly, the commission studied different options and had open discussions with a broad segment of society and international specialists to arrive at a concrete proposal. It is clear that difficult decisions will need to be made to make the pension system sustainable. However, the National Assembly approved a reform of the social security system on May 2005 that, if implemented, would accelerate the onset of the pension system's cash-flow problems and weaken the institutional framework for the system. As part of a process of developing internal consensus for reforms, we reached agreement with the political parties to postpone implementation of this law until after January 2007. This gives us time to prepare a detailed roadmap spelling out how to bring Nicaragua's pension system back into actuarial solvency without relying on government financing beyond the coverage of transitional costs. A structural performance criterion has been established under the program to have this plan ( $\$ 30$ of the TMU) prepared by June 2006 for discussion with interested parties and consideration by the government after the elections.

\section{A new tax code was approved in October 2005, but with significant weaknesses}

that we intend to address. Introducing a tax code to strengthen tax administration in line with international best practices has been a key policy priority, with particular emphasis on auditing, payment enforcement and sanctions. However, the version of the law that has been passed has a number of crucial weaknesses that need to be addressed urgently. These included: (i) limitations on the capacity of the tax administration (DGI) to request information from tax payers, (ii) excessive discretion for the DGI to waive sanctions, (iii) an overly time consuming system of appeals against the DGI's findings on tax liabilities, (iv) a tax audit system that in practice would prevent the DGI from conducting "desk audits," (v) introduction of limitations on tax payers' liability in cases where returns are audited by third parties ("dictamen fiscal"), (vi) inclusion of a "positive silence rule" together with a relatively short statutory period for DGI's rulings, (vii) lack of penalties for filing amended tax returns when this is done within a 30-day period, and (viii) too rigid a system for dealing with delays in the collection of tax liabilities ("efectos de mora"). Given the risks to the continued effectiveness of the DGI, we intend to move quickly to strengthen the law. The program includes an end-March 2006 performance criterion that the tax code be amended by the National Assembly to address the concerns discussed here (TMU 127). These amendments are crucial to give the tax administration the powers it needs to administer effectively the tax system and to help raise taxpayers' compliance levels.

\section{We are committed to reform the framework for the energy sector and} strengthen the recently approved Energy Stability Law (ESL). Encouraging investment in the power sector to develop alternative energy sources and foster competition are key elements of our strategy. In response to the crisis in the power sector, the ESL was approved in September 2005, but, however, needs strengthening. The ESL provides the basis for the regulator to adjust electricity rates on a high frequency basis (the previous framework allowed adjustments only once per year). However, this law includes the capping of electricity spot market prices and interventions in the market for petroleum products. There are reasons for concern that these measures might create disincentives for future investment 
and there is a need to review their potential distortionary effects. However, we need time to conduct a thorough assessment of the options for further reform of the sector. As a first step in this direction, the program will introduce as a structural performance criterion for endAugust 2006 that the ESL be amended to eliminate distortions ( $₫ 32$ in the TMU).

\section{We have made substantial progress in strengthening the financial sector} framework in line with FSAP recommendations. The national assembly this year approved a new banking law, and laws for the superintendency of banks and deposit insurance scheme (FOGADE). Together, these laws embody several key reforms, including: (i) strengthening the independence of the Superintendency; (ii) strengthening the legal framework for consolidated supervision; (iii) improving banking resolution procedures; (iv) enhancing the deposit insurance scheme; and, (v) reducing excessive scope for banking secrecy. We have made further amendments to these laws to strengthen the intervention process and increase safeguards against political interference in the day-to-day operations of the superintendency.

\section{Following on this, we intend to prepare a roadmap for further financial sector} reform for consideration by the next government. Core elements of this plan will be to advance on the remaining key FSAP recommendations and especially to develop steps for supporting the development of the domestic capital markets. Important outstanding FSAP recommendations that the roadmap will cover include: strengthening the independence and financial position of the central bank, continuing reforms of the judicial framework for the financial sector, strengthening the framework for management of land titles, and eliminating maximum lending interest rates of micro-finance companies. Advancing in these areas will require legislative measures including passage of the Law's on Capital Markets, Microfinance, Warehouse Deposits as well as reforms of the laws on the Central Bank and Insurance. The program includes a structural benchmark on presentation of the roadmap to the economic cabinet by August 2006 ( $\{31$ of the TMU).

\section{A key area for future reform will be strengthening legal protection afforded to} bank supervisors, which is currently insufficient. After a comprehensive review of the legal options to extend the protection of bank supervisors to include criminal liability, we have found the avenues for progress in this area to be limited by constitutional considerations. We intend, however, to continue to work on this issue, in order to identify concrete measures to protect bank supervisors from criminal suits for actions undertaken in the course of their duties and will prepare options for consideration by the new government after the elections in the context of the roadmap for financial sector reform.

20. Poverty reduction remains a critical and central element of our policy platform. We have prepared a document to implement the Government's National Development Plan (PRSP-II), which undertakes a major review of our first Poverty Reduction Strategy Paper (PRSP-I). The PRSP-II emerged from a broad participatory process comprising the poverty reduction plans at the sub-national level. Critical to our policy platform are the objectives of poverty reduction and achievement of the Millennium Development Goals through economic growth, employment generation, increased investment and export promotion. Additional 
strategic areas emphasized in the PRSP-II are: human capital development and social protection, productive and social public infrastructure, and good governance and state reforms. The government will sustain poverty spending at 13.4 percent of GDP in the 2005 budget and a similar percentage for 2006 .

\section{Other Issues}

\section{The government is committed to strengthening debt management to support} long term fiscal sustainability. In addition to the implementation of sound macroeconomic policies, including fiscal consolidation as described above, we have continued active negotiations for debt relief, in good faith, with all our creditors in the context of the HIPC initiative. Negotiations have been completed with all our Paris-Club and almost all our multilateral creditors, as well as a number of non-Paris Club creditors. However, negotiations have proven difficult with several other non-Paris Club creditors. We have hired financial and legal advisors to help us negotiate debt relief from our commercial creditors, with whom we aim to settle claims through the IDA Debt Reduction Facility. Even after full delivery by all creditors of all expected HIPC relief, our debt level will remain above internationally recognized sustainability thresholds. In that context, we welcome the recent Multilateral Debt Relief Initiative (MDRI) to provide further relief on debt outstanding to the Fund and IDA, and we look forward to benefiting from it at an early point. Finally, we also enhanced our debt monitoring system by publishing a quarterly report on external and domestic debt.

22. We plan to further strengthen the monitoring of fiscal performance. We are working to shift the fiscal accounts (including debt service) to a modified accrual basis. We will begin to monitor central government transactions on an accrual budgetary basis (defined under the FAL) from January 2006. In order to eventually move toward accrual accounting, we will prepare by June 2006, a budgetary classification manual of the nonfinancial public sector. We also plan to strengthen our capacity to monitor the fiscal accounts from the financing side to ensure consistency of financial data with the fiscal statistics derived from the CPS data. The program introduces structural benchmarks on both these measures ( $₫$ 's 33 and 34 of the TMU).

\section{Program Issues}

23. We are requesting a simplification of the quantitative program conditionality for 2006 to improve program monitoring, eliminate redundancies and increase transparency. We believe that the performance criteria on the central government overall balance (after grants) and on repayment of BCN and central government debt are no longer necessary, given the broader fiscal target on the combined public sector. However, given recent challenges, new performance criteria on the central government wage bill and the level of electricity tariffs are being introduced. We would like to make the primary balance of the central government a new indicative target, to maintain the focus on the central government's medium-term debt dynamics. We believe also that the indicative targets on primary spending of the central government, net domestic financing to the nonfinancial public sector, savings 
of the combined public sector, and the overall balance of the combined public sector (before grants) are no longer needed.

\section{We believe that a number of definitions of program targets should be changed.} In that context we are requesting that the fiscal program targets be defined on a basis that is consistent with our budget presentation. We therefore request that the past program convention of including HIPC relief from multilaterals in the fiscal accounts as grants be discontinued. Program fiscal targets for 2006 should be set based on this revised treatment. Also, we are considering for future programs strengthening the definition of adjusted NIR by not counting foreign currency reserves of the deposit insurance fund that are maintained at the central bank and currently added to adjusted NIR.

25. We also request that the program quantitative targets be adjusted once we are able to receive relief under the MDRI to: (i) allow an increase in poverty-reducing spending by the amount of the debt service that would not be made as a result of the implementation of the MDRI (the fiscal deficit targets would be relaxed accordingly by the amount of debt relief which applies to principal payments); and (ii) account for the change in $\mathrm{BCN}$ short term external liabilities resulting from any write off of the stock of debt to the Fund.

\section{Implementation of the 2006 program under the PRGF arrangement will be} monitored through quarterly reviews based on the observance of quarterly quantitative performance criteria, indicative targets and benchmarks (end-March 2006 and end-June 2006) as well as relevant structural performance criteria for end-March 2006 and end-August 2006. Quantitative and structural performance criteria are presented in Tables 1 and 2, and defined in the attached Technical Memorandum of Understanding. 
Table 1. Nicaragua_Prior Actions, Structural Performance Criteria, and Benchmarks for Completion of Reviews

\begin{tabular}{|l|l|l}
\hline & Date of & on
\end{tabular}

\section{Prior Actions for Completion of Reviews}

- $\quad$ Passage of 2006 budget consistent with the program including a CPS deficit (after grants) of 2.2 percentage points of GDP.

Done.

November 2005

Wage bill grows slightly above expected average inflation.

Done. Implementation

Done. Law was amended to strengthen

Done.

Done. Law was amended to strengthen

Done. Law was amended to strengthen

Done.

Done.

November 2005

November 2005

August 2005

November 2005

November 2005

November 2005

October 2005

October-December
- 2006 budgetary wage bill consistent with expected average inflation.

- Decentralization - devolution of expenditures equivalent to half of revenue transfer to municipalities

- $\quad$ Passage of a satisfactory law on financial administration (FAL)

- $\quad$ Passage of a satisfactory banking law

- $\quad$ Passage of a satisfactory deposit insurance law.

- $\quad$ Passage of satisfactory superintendency law

- Defer implementation of social security law pending for review by new government after election

- $\quad$ Electricity tariff adjustment of at least 10 percent 2005

March 31, 2006

June 30, 2006
- Preparation of a detailed strategy and
implementation plan on pension reform (TMU

- Preparation of a detailed strategy and
implementation plan on pension reform (TMU 30)

- Publication of a detailed implementation plan
spelling out the roadmap toward adoption of a

- $\quad$ Publication of a detailed implementation plan
spelling out the roadmap toward adoption of a Fiscal Responsibility Law in 2007 (TMU $\mid 29)$.

- $\quad$ Energy stability law amended to eliminate

distortions (TMU $\mid 32$ )

Passage of a satisfactory tax code, that strengthens administration, including auditing, payment enforcement and sanctions (TMU $\$ 27)$. 
Table 1. Nicaragua-Prior Actions, Structural Performance Criteria, and Benchmarks for Completion of Reviews

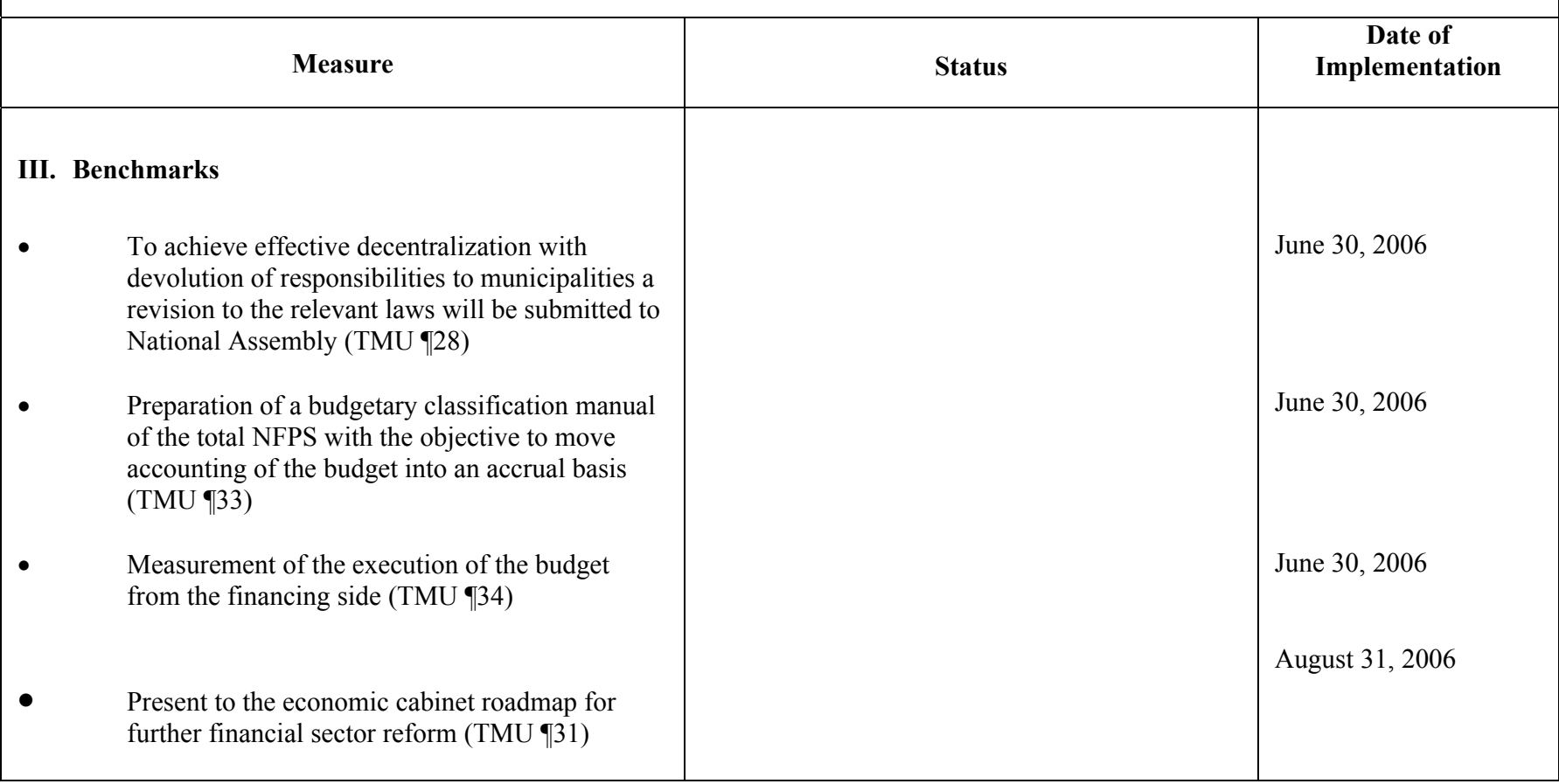

1/ The specific requirements for the implementation of these measures are specified in the TMU. 
Table 2. Nicaragua: Quantitative Performance Criteria

\begin{tabular}{|c|c|c|c|c|c|}
\hline \multicolumn{6}{|c|}{2004} \\
\hline end- & & end-Sep & nber & end-Dec & aber \\
\hline Program & Actual & Program & Actual & Program & Actual \\
\hline
\end{tabular}

(In millions of cordobas)

\section{Performance Criteria}

Net domestic financing of the combined public sector (ceiling)

Savings of the combined public sector (floor)

Net domestic assets of the central bank (ceiling)

Central government overall balance, after grants (floor) $2 /$

Combined public sector overall balance, after grants (floor) 2/

Net international reserves of the central bank (floor)

Net repayment of public domestic debt $(+)$ (floor) 3/

Disbursements of nonconcessional external debt contracted

or guaranteed by the public sector (ceiling) $1 /$

Stock of external payments arrears (ceiling) 1/

\section{Indicative targets}

Savings of the combined public sector (floor)

Tax revenue of the central government (floor)

Total primary expenditure of the central government (ceiling) 2/

Overall balance of the combined public sector, before grants (floor) 2/

Net domestic financing of the nonfinancial public sector (ceiling) 2/

\section{Memorandum items (millions of US\$):}

Privatization

BOP support

WB-IDB project disbursements

$\begin{array}{rrrrrr}-1,146 & -3,067 & -2,636 & -2,836 & -2,884 & -3,297 \\ 1,199 & 1,753 & \ldots & \ldots & \ldots & \ldots \\ -308 & -1,800 & -867 & -1,289 & -91 & -1,446 \\ \ldots & \ldots & -581 & -499 & -572 & -1,060 \\ \ldots & \ldots & -1,517 & -797 & -2,087 & -1,591\end{array}$

(In millions of U.S. dollars)

$\begin{array}{rrrrrr}5 & 101 & 37 & 73 & 20 & 128 \\ 47 & 48 & 64 & 64 & -9 & 101 \\ & & & & & \\ 0 & 0 & 0 & 0 & 0 & 0 \\ 0 & 0 & 0 & 0 & 0 & 0\end{array}$

(In millions of cordobas)

$\begin{array}{rrrrrr}\ldots & \ldots & 1,415 & 2,030 & 1,645 & 2,523 \\ 5,412 & 5,624 & 8,511 & 8,648 & 11,416 & 11,798 \\ 6,109 & 6,232 & 10,207 & 9,935 & 13,676 & 14,721 \\ -2,018 & -1,373 & -4,186 & -2,965 & -5,758 & -5,204 \\ -1,884 & -3,697 & -3,712 & -3,699 & -4,374 & -4,329\end{array}$

$\begin{array}{llllll}51 & 50 & 51 & 51 & 61 & 64\end{array}$

$\begin{array}{llllll}50 & \ldots & 65 & 50 & 80 & 95\end{array}$

$\begin{array}{llllll}102 & \ldots & 727 & 135 & 125 & 227\end{array}$

\footnotetext{
Sources: Central Bank of Nicaragua; Ministry of Finance; and Fund staff estimates/projections.

1/ Continuous performance criteria.

2/ Includes WB/IDB investment adjustor for C\$611 and C\$886 million for September and December of 2004, respectively.

3/ Includes adjustor for US\$123 in 2004, as a result of accumulatring NIR and BOP support disbursements higher than program targets.
} 
Table 3. Nicaragua: Quantitative Performance Criteria, 2006

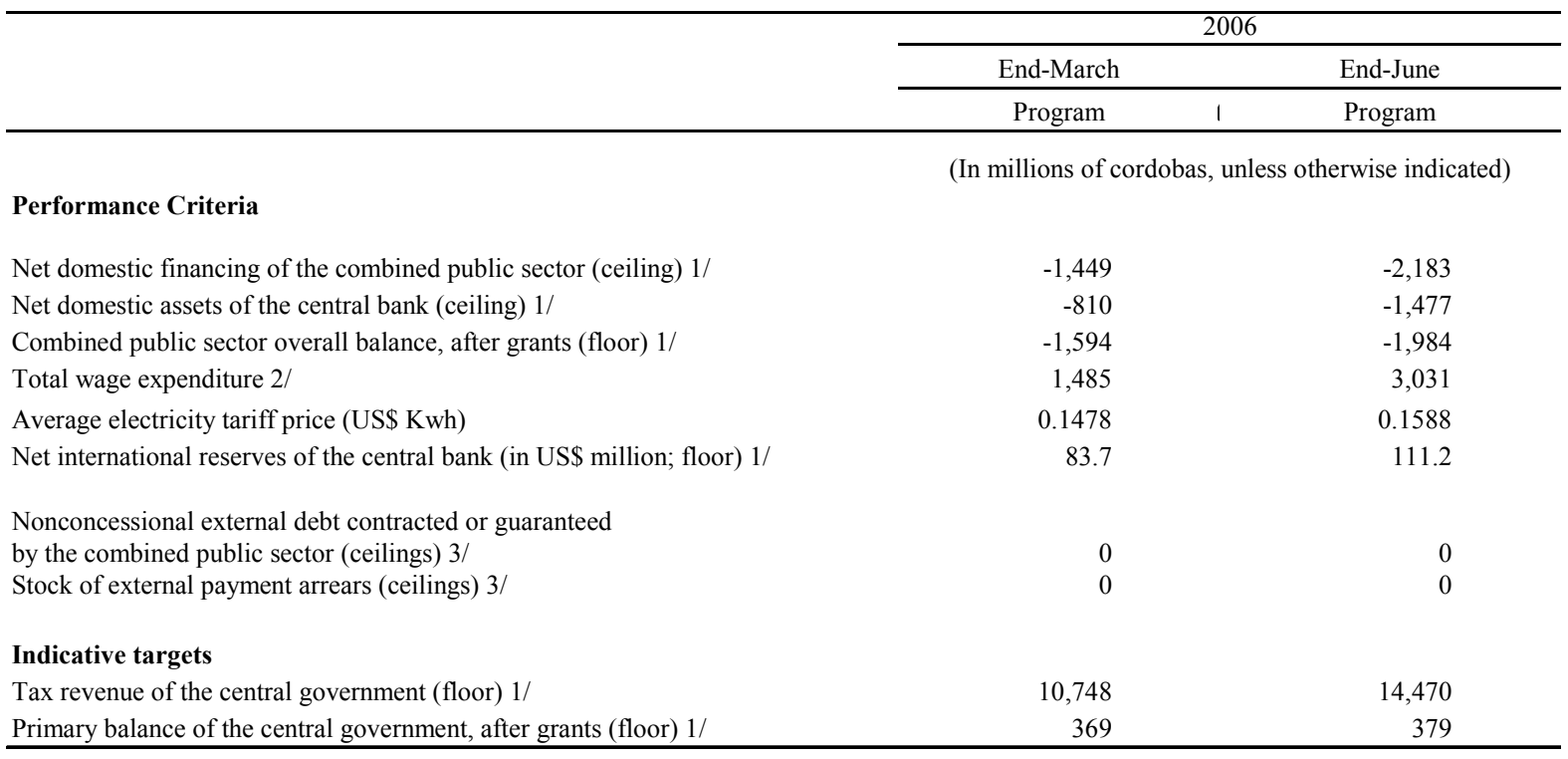

Sources: Central Bank of Nicaragua; Ministry of Finance; and Fund staff estimates/projections.

1/ Cumulative flows starting July 1, 2005.

2/ Cumulative flows starting January 1, 2006

3 / In US dollars. Measured on a continuous basis 


\section{NiCARagua-Technical Memorandum OF Understanding}

1. This technical memorandum summarizes the understandings between the Fund and the Nicaraguan authorities relating to the monitoring of the Poverty Reduction and Growth Facility (PRGF) arrangement. For program purposes, all quantitative performance criteria and indicative targets will be defined as cumulative flows from June 30, 2005.

\section{A. Definitions}

\section{Fiscal Targets}

2. Coverage of the fiscal accounts:

- $\quad$ Nonfinancial Public Sector (NFPS) includes the central government (CG), the social security institute (INSS), the municipality of Managua (ALMA), the electricity transmission public enterprise (ENTRESA), the water and sewerage company (ENACAL), the electricity holding company (ENEL), the telecommunications regulatory agency (TELCOR) and the port company (EPN).

- $\quad$ The Combined Public Sector (CPS) includes the NFPS and the Central Bank of Nicaragua $(\mathrm{BCN})$.

3. Central Government Overall Balance is defined as the total revenues of the CG minus primary expenditures of the $\mathrm{CG}$ and minus domestic and external interest expenditures of the CG.

- Total revenues of the CG are defined on a cash basis as the sum of revenues from tax collections, nontax revenues, capital revenues, and current transfers.

- $\quad$ Primary expenditures of the CG are defined on a cash basis as the sum of wages and salaries, other goods and services, current and capital transfers, capital expenditure, and net lending.

- Interests on domestic and external debt are registered on a cash basis for program purposes.

4. Foreign Grants to the Central Government are equal, for program purposes, to total tied and untied grants to the CG.

5. Overall Balance of the Central Government (after grants) is equal to the overall balance of the CG plus foreign grants to the CG.

6. Primary Balance of the Central Government (after grants) is equal to the overall balance of the CG (after grants) plus interests on total debt of the CG. 
7. Overall Balance of the Combined Public Sector (after grants) is defined as the CG overall balance plus the operating result of the BCN plus the overall balances of INSS, ALMA and the public enterprises included in the definition of the CPS, plus foreign grants to the CPS.

8. The Net Domestic Financing of the Combined Public Sector comprises the operating result of the BCN and the change from their respective stocks at end-June 2005 of the sum of (a) the outstanding stock of debt of the NFPS to the domestic financial system (BCN, commercial banks, and the Fondo Nicaragüense de Inversiones-FNI) net of deposits (including arrears that correspond to obligations considered eligible for refinancing or rescheduling, or other debt reduction mechanisms) with the foreign currency part of the net debt to the banking system converted into córdobas at the program exchange rate; (b) the outstanding stock of domestically-issued public sector debt held by private residents or nonresidents with the foreign currency part converted into córdobas at the program exchange rate; (c) the outstanding stock of suppliers' credit; and (d) the outstanding stock of floating debt.

\section{Total wage expenditures, which will be monitored under the quantitative} performance criterion, should grow by no more than 9.7 percent in 2006 relative to 2005, and is defined as the sum of personnel expenditures (Budgetary classifications line item 01 of expenditures and line item 05 of Ministry of Education, Culture, and Sports) of current and capital expenditures of most central government entities included in the budget. The entities included are the following: National Assembly, Supreme Court of Justice, Supreme Electoral Council, Comptroller of the Republic of Nicaragua, Presidency and Vicepresidency of the Republic of Nicaragua, Ministry of Labor, Ministry of Finance, Ministry of Industry and Commerce, Ministry of Transportation and Infrastructure, Ministry of Agriculture and Forestry, Ministry of Foreign Affairs, Ministry of Environment and Natural Resources, Ministry of the Family, Ministry of Education, Culture, and Sports, Decentralized and Autonomous Education Institutions, Ministry of Health, Ministry of the Interior, Ministry of Defense (including the army), Attorney General of the Republic of Nicaragua.

10. Electricity tariffs, which will be monitored under the quantitative performance criterion are defined as the average tariff price charged by the electricity distributor to consumers. The energy purchase reference price is defined as the generation component of the average tariff price. Based on the end-October tariff price, which was $0.1353 \mathrm{US} \$ / \mathrm{KWh}$, tariffs will be further increased up to an average tariff of $0.1588 \mathrm{US} \$ / \mathrm{KWh}$.

Electricity tariffs: 2005

1-Jan-05 16-Jul-05 16-Aug-05 1-Oct-05 31-Dec-05

\begin{tabular}{lccccc}
\hline Reference price (US\$/MWh) & 71.74 & 78.14 & 79.84 & 82.43 & 84.90 \\
Average tariff price (US\$/KWh) & 0.1230 & 0.1304 & 0.1324 & 0.1353 & 0.1394 \\
Tariff adjustment & 0.00 & $5.98 \%$ & $1.50 \%$ & $2.25 \%$ & $3.00 \%$
\end{tabular}




\section{Monetary Targets}

11. Adjusted Net International Reserves (NIR) of the BCN are defined as

- Gross foreign assets of the BCN that are readily available (which exclude those that are pledged or otherwise encumbered including, but not limited to, reserve assets used as collateral or guarantee for a third-party external liability;

- Minus short term reserve liabilities of the $\mathrm{BCN}$ including purchases and credits from the IMF;

- Minus foreign currency reserve requirement deposits of the commercial banks at the $\mathrm{BCN}$.

12. The Net Domestic Assets (NDA) of the BCN target under the program is defined as the difference between the change in the stock of currency issued and the change in NIR valued at the program exchange rate.

13. For 2006, the program exchange rate is 17.6 córdobas for one US dollar.

\section{External Sector Targets}

14. Non-concessional debt of the combined public sector will be defined as the contracting or guaranteeing of non-concessional external debt of the CPS, or by any other agencies on behalf of the CPS. This limit applies not only to debt as defined in Point No. 9 of the Guidelines on Performance Criteria with Respect to Foreign Debt adopted by the IMF on August 24, 2000, but also to commitments contracted or guaranteed for which value has not been received. External debt includes all current liabilities with a nonresident party, which are created under a contractual arrangement through the provision of value in the form of assets (including currency) or services, at some future point(s) in time to discharge the principal and/or interest liabilities under the contract. This definition includes loans, suppliers' credits, and leases (operational and financial leases). The ceiling on contracting of non-concessional external debt applies both to medium-and long-term debt defined as debt with maturity of one year or longer, as well as to short-term debt, defined as debt with maturity of less than one year. For program purposes, BCN instruments placed in the domestic market held by nonresidents, will be excluded from the ceiling on the contracting of non-concessional external debt. Debt with a maturity of less than one year for import related credits, BCN reserve liabilities of less than one year, and borrowing from the Fund are excluded from the ceiling.

15. Concessionality will be based on currency-specific discount rate on the 10 year average of the OECD's commercial interest reference rates (CIRR) for loans or leases with maturities greater than 15 years and on the six-month average CIRR for loans or leases maturing in less than 15 years. Maturity will be determined based on the original loan 
contract. Under this definition of concessionality, only debt with a grant element equivalent to 35 percent or more will be excluded from the debt limits.

16. External Payment Arrears are defined as debt service obligations arising from external debt contracted or guaranteed by the public sector overdue by more than 15 days, except on external debt subject to rescheduling or restructuring.

17. Balance of Payments or Budget Support is defined as official external untied financial assistance from loans and grants provided by foreign official entities that are received by the government for unrestricted budgetary use.

\section{B. Reporting}

\section{The BCN will send to the IMF by electronic mail:}

- A daily report containing information on the daily accounts of the BCN with a two day lag (stocks and flows);

- A monthly report with information on the monthly accounts of the BCN within four weeks and commercial banks, and FNI (stocks and flows) within six weeks of the end of the month;

- Quarterly accounts of the BCN within four weeks of the end of the quarter and commercial banks, and FNI (stocks and flows) within six weeks of the end of the quarter.

- Monthly information on the detailed operations of the combined public sector no later than five weeks after the end of each month.

- Monthly information on the accounting of non-reschedulable external arrears by creditor (if any), with detailed explanations, within four weeks of the end of each month.

- Monthly information on the accounting of domestic arrears by creditor (if any), with detailed explanations, within four weeks of the end of each month.

\section{The Ministry of Finance will send to the IMF by e-mail the following information:}

- Quarterly information on loan-by-loan accounting of all new loans contracted or guaranteed by the public sector-including detailed information on the amounts, currencies, and terms and conditions, as well as relevant supporting materials - within four weeks of the end of each quarter.

- Quarterly information on issuance and redemption of BPIs within four weeks of the end of each quarter. 
- Monthly information on exonerations and exemptions granted by the customs administration (DGA) by type of tax no later than five weeks after the end of each month, and quarterly information on exonerations and exemptions granted by the internal revenue administration (DGI) by type of tax no later than six weeks after the end of each quarter.

\section{Adjustors}

20. The Overall Balance of the Combined Public Sector (after grants) target will be adjusted downwards by the amount of principal payments to IDA and the IMF that would not have to be made as a result of the possible implementation of the Multilateral Debt Relief Initiative (MDRI).

21. The Primary Balance of the Central Government targets will be adjusted downwards by the amount of total debt service of the government and central bank that would not have to be made as a result of the possible implementation of the MDRI.

22. The net domestic financing of the combined public sector target will be adjusted upwards by the amount of principal payment to the IMF that would not have to be made as a result of the possible implementation of the MDRI.

23. In the event that the MDRI is implemented, the NIR target will be adjusted upwards by the amount of stock of debt subject to IMF cancellation, minus any principal payment (including those covered by HIPC relief) that would have been scheduled in the absence of the MDRI between the date of implementation of the MDRI and the test date.

24. In the event that the MDRI is implemented, the NDA target will be adjusted downwards by the amount of stock of debt subject to IMF cancellation, minus any principal payment (including those covered by HIPC relief) that would have been scheduled in the absence of the MDRI between the date of implementation of the MDRI and the test date.

25. The NIR target will be adjusted downwards (respectively upwards) by the cumulative amount of any shortfall (respectively excess), up to a maximum total of US\$ 25 million, in balance of payments/budget support loans disbursed by the World Bank and the Interamerican Development Bank as specified in Table 1.

26. The net domestic financing of the combined public sector and NDA targets will be adjusted upwards (respectively downwards) by the cumulative amount of any shortfall (respectively excess), up to a maximum total of US\$25 million, in balance of payments/budget support loans disbursed by the World Bank and the Interamerican Development Bank as specified in Table 1. 
Table 1. Expected World Bank and IDB

budgetary/balance of payment support loans

(Cumulative flows since end-June 2005, millions of US\$)

\begin{tabular}{lcc}
\hline & $2006 \mathrm{Q} 1$ & $2006 \mathrm{Q} 2$ \\
\hline Total & 65 & 75 \\
World Bank & 35 & 35 \\
IDB & 30 & 40 \\
\hline
\end{tabular}

\section{Structural Conditionality}

Tax code (performance criterion)

27. The amendments to the tax code, which will be discussed with Fund staff before being submitted to the National Assembly, should include, but not be limited to the following:

- Tax administration power to request information. All taxpayers and government entities should, for tax purposes, supply the information the tax administration requests in the form and time frame that the tax administration deems necessary. To this purpose there should be no need for a prior judicial order (Art. 27 of the tax code (TPC));

- Ability to conduct off-site audits: The tax administration should have the authority to audit taxpayers at their legal address as well as in the tax administrations' office and other sites that it may deem appropriate. (Art. 67, Art. 27, and Art. 103, Num. 10 TPC);

- Administrative silence. If the tax administration or the tax tribunal does not issue a ruling on a case initiated by the taxpayer within the statutory time frame, this "silence" should be interpreted as a negative answer to the petition and the taxpayer would then have the option to either appeal that tacit ruling or wait until the ruling is actually issued (Arts. 97, 98 and 99 TPC);

- Suspension of the collection enforcement process. A system of guarantees to be provided by the tax payer with tax obligations above a threshold that will be defined in the law, should be established, in order to defer collection action by the tax administration against tax payers with regards disputed tax claims (Art. 95 TPC);

- Discretion to Waive Sanctions. The tax administration should not have the power to waive sanctions and penalties for non-compliance (Arts. 129 and 137 TPC);

- Audit Certification ("Dictamen Fiscal"). The Dictamen Fiscal should not limit the audit powers of the tax administration. Further, even if the taxpayer uses the audit 
certification, he/she should continue to be responsible for any error or omissions in the tax return. (Art. 156 TPC).

\section{Decentralization (benchmark)}

28. Amendments to the municipal transfer and municipality laws next year should be made to achieve fiscal neutrality by explicitly linking revenues transferred to municipalities to expenditure responsibilities that have been devolved to them. The amendments should also make clearer the specific nature and modalities of the expenditure responsibilities that are devolved to municipalities and make other associated changes to the overall decentralization and budgetary framework, to support the achievement of effective decentralization.

Fiscal Responsibility Framework (performance criterion)

29. The roadmap to achieve an effective framework for fiscal responsibility should include, but not be limited to, a discussion of the following key elements:

1) Ministry of Finance (MHCP)'s increased control over the design and execution of the budget. The roadmap should explore the following issues:

- Expand coverage of entities covered in the budget such that decentralized agencies by function are fully integrated into the annual budget.

- Increase expenditure flexibility, including by addressing earmarking. A large percentage of expenditures are currently earmarked, which hampers the ability of the ministry of finance to achieve effective fiscal management.

- Complete the process of centralizing budget functions to strengthen the MHCP's control of expenditure ceilings of decentralized agencies, as well as the capital budget.

2) Development of a Multiyear Macroeconomic Plan (MMP). The roadmap will discuss what should be the key features of the MMP in the context of international experience with fiscal responsibility laws. These features could include: (i) statement of the principles of fiscal policy that the government will pursue (including management of unexpected revenues), (ii) presentation of key macroeconomic targets (such as annual reductions in the public debt-to-GDP ratio, medium-term primary surplus targets for the central government, as well as debt ceilings for local governments, and state-owned enterprises), (iii) responsibility for preparation of the MMP, (iv) macroeconomic projections for the current year and the subsequent three years, and (v) link to targets of the Annual Budget Law as well as its modifications during the year.

3) Monitoring and corrective action clauses. The roadmap should study how the implementation of the MMPs targets will be assessed and reported on during the course 
of the year. A discussion should be included regarding who would be responsible for achieving the agreed targets.

4) Escape clause. The roadmap should note that appropriate circumstances for deviating from the MMPs targets should relate to emergency situations only (such as in cases of national emergency defined under the Law, including outbreaks of epidemic diseases, natural disasters, and war), and discuss who could grant these waivers (in case waivers are to be granted by the National Assembly, the law should clearly constrain the circumstances when these can be granted).

5) Sanctions for noncompliance. The roadmap will discuss: (i) accountability for meeting the MMP targets, (ii) sanctions for non-compliance against those judged responsible as well as responsibility for assessing and enforcing sanctions. The plan should study the trade-offs between stronger sanctions and pressures to include multiple escape clauses and a narrower coverage of the public sector in the fiscal framework.

6) Inclusion of local governments. As local governments play an increasingly important fiscal role in Nicaragua, the fiscal responsibility framework should consider a timetable and outline the necessary conditions for their incorporation into the framework.

7) Role of political consensus. The roadmap should discuss a strategy for developing consensus and political support for adoption of the fiscal responsibility framework.

8) Assess the constitutional implications of the fiscal responsibility framework including the recently approved FAL. The roadmap should assess what changes to the FAL and what constitutional amendments may be needed for a credible fiscal responsibility framework.

9) Timeframe. The roadmap should spell out the timeframe for adopting the fiscal responsibility framework and the sequencing of the needed reforms.

10) Modalities. The roadmap should be prepared by a committee appointed by the Minister of Finance and including high level representatives from the MHCP, Central Bank of Nicaragua and the Economic Commission of the National Assembly and be ready by end-June 2006.

Pension Reform (performance criterion)

30. The Pension Reform Plan should estimate the fiscal costs of the various alternatives currently being considered and recommend a specific strategy to bring the pension system into actuarial solvency. The analysis should include, but not necessarily be limited to, sensitivity analyses on parametric reforms (such as changes to the retirement age, minimum number of contributions, minimum pension, replacement rate), the relative advantages and disadvantages of alternative pension schemes, and the different parameters used in the estimation of the transition costs. The plan should include a specific recommendation of a scheme that would move Nicaragua's pension system into actuarial 
solvency without relying on any government financing beyond the coverage of possible transition costs. It should include the steps and timeline for implementation of the pension reform, including the needed parametric reforms, which could be carried out as a first, step, and also include time for discussion among all stakeholders and a schedule for introducing the reforms. The plan should be prepared by a new commission appointed by the Minister of Finance and including high level representatives from the MHCP, Social Security Institute, Central Bank of Nicaragua and the Economic Commission of the National Assembly, and be ready by end-June 2006 .

\section{Financial Sector Reform (benchmark)}

31. The roadmap for future financial reform should be prepared by a committee including representatives from $\mathrm{MHCP}$, the Superintendency, the Central Bank and FOGADE and include, but not necessarily be limited to, the following key elements: strengthening the financial position of the central bank, strengthening the framework for management of land titles, and eliminating maximum lending interest rates of micro-finance companies. The roadmap should include a timetable for passage and a discussion of the main content of key laws including: (i) Capital Markets Law, (ii) Central Bank Charter, (iii)Microfinance Law, (iv) Warehouse Deposits Law, and (v) a General Insurance Law. The roadmap should also include a discussion of needed reform of the judicial framework for the financial sector.

\section{Energy Stability Law (ESL) (performance criterion)}

32. The ESL will be amended to: (i) strengthen the regulation of the electricity spot market while eliminating controls on spot market prices for electricity, and (ii) strengthen the regulatory framework for fostering competition in the market for petroleum products while eliminating the possibility of introducing price controls and other arbitrary interventions in this market.

\section{Public Expenditure Management (benchmarks)}

33. With a view to eventually moving to the accounting of the budget on an accrual basis, a budgetary classification manual of the total NFPS will be prepared by end-June 2006 as a structural benchmark under the program.

\section{With a view to eventually measuring the execution of the budget from the} financing side (below the line), a study will be prepared to: (i) assess the problems that are currently preventing the computation of the below-the-line-financing, and (ii) recommend ways to address this problem, including a timeframe for implementing the recommendations. The finalization of this study by end-June 2006 will be a structural benchmark under the program. 


\section{E. Safeguards Assessment}

35. To address the vulnerabilities identified during the safeguards assessment of the BCN completed in August 2003, we propose the following timetable:

\begin{tabular}{ccc}
\hline Measures & $\begin{array}{c}\text { Expected Date of } \\
\text { Implementation }\end{array}$ & Status \\
\hline
\end{tabular}

1. International Financial Reporting Standards (IFRS)

- Disclose the differences between IFRS and the BCN accounting practices:
(i) in the 2002 financial statements.
(ii) in the 2003 financial statements.
(iii) in the 2004 financial statements.
(iv) in the 2005 financial statements.
(v) in the 2006 financial statements.

$\begin{array}{cc}\begin{array}{c}\text { October 2003 } \\ \text { end-June 2004 }\end{array} & \text { Done } \\ \text { End-June 2005 } & \text { Done } \\ \text { End-June 2006 } & \text { Done } \\ \text { End-June 2007 } & \\ 2007 & \begin{array}{c}\text { Awaiting } \\ \text { recommendations } \\ \text { from external } \\ \text { auditors }\end{array}\end{array}$

2. Cleaning of Central bank's general balance

December 2006

August 2006

October, 2005

June 2006

December 2006
In process

In process

Done

In process Pending

36. In order to adopt IFRS, the BCN hired a new external auditor in April 2004 for a three-year period and established a program to ensure adequate training for the staff of the accounting department and to identify the necessary changes to the central bank law. The auditor performed the reconciliation of the 2003 financial statements and prepared a report that facilitated the establishment of a plan to initiate migration from Nicaraguan accounting standards to IFRS by the end of the year 2006. 


\section{Statement by the IMF Staff Representative January 18, 2006}

Since the issuance of the staff report, the following additional information has become available. This information does not alter the thrust of the staff appraisal.

- Inflation in $\mathbf{2 0 0 5}$ was slightly lower than projected. Preliminary full year data indicate that inflation at end-2005 was 9.6 percent $y / y$ as compared with the projected 10.5 percent. Lower-than-expected inflation reflects mainly some reduction in domestic prices of petroleum products in line with international prices.

- Tax revenues remained on track in 2005. Preliminary data through end-December indicate that tax revenues in 2005 were in line with program projections of 17.6 percent of GDP, with nominal y/y growth slightly above 20 percent.

- International reserves ended the year stronger than projected. Adjusted NIR increased by US\$71 million in 2005, as compared to the projection of a US\$15 million increase, such that the stock of adjusted NIR stood at US\$282 million at end-2005. This reflects mainly a higher than expected accumulation of government deposits at the central bank in December. Data are not yet available to explain the breakdown of the higher than programmed government deposits. This could reflect a combination of delays in the execution of spending and higher than programmed net external financing during December. 


\section{INTERNATIONAL MONETARY FUND}

Public Information Notice

\section{IMF Executive Board Concludes 2005 Article IV Consultation with Nicaragua}

On January 18, 2006, the Executive Board of the International Monetary Fund (IMF) concluded the Article IV consultation with Nicaragua. ${ }^{1}$

\section{Background}

Nicaragua has made many important advances in the last few years. The economy has grown and poverty has fallen in the context of a stable macroeconomic environment that has supported real incomes of the poor and created more jobs. Several key reforms have advanced in the areas of improving revenues, and strengthening governance and the financial sector framework.

Following a decade of economic decline, the return to democracy and adoption of economic reforms in the early 1990s generated a strong recovery. Nonetheless, this period also saw the emergence of new vulnerabilities, including high fiscal deficits and a widening current account deficit financed in large part by official transfers. Moreover public sector debt levels remained elevated at close to 200 percent of GDP. In 2000-01, the economy deteriorated sharply following a severe banking crisis, a weakening of fiscal and monetary policy and a deterioration in the external environment.

\footnotetext{
${ }^{1}$ Under Article IV of the IMF's Articles of Agreement, the IMF holds bilateral discussions with members, usually every year. A staff team visits the country, collects economic and financial information, and discusses with officials the country's economic developments and policies. On return to headquarters, the staff prepares a report, which forms the basis for discussion by the Executive Board. At the conclusion of the discussion, the Managing Director, as Chairman of the Board, summarizes the views of Executive Directors, and this summary is transmitted to the country's authorities.
}

Washington, D.C. 20431 • Telephone 202-623-7100 • Fax 202-623-6772 • www.imf.org 
The government that took office in 2002 moved quickly to address the large imbalances, tightening the fiscal and monetary policy stance. The authorities' economic program was supported by a PRGF arrangement approved in December 2002. Real GDP growth increased from 0.8 percent in 2002 to 5.1 percent in 2004 and inflation remained stable, averaging 6.6 percent in this period. Nicaragua reached the HIPC completion point in January 2004 and the NPV of the country's external debt should fall from 120 percent of GDP at end-2004 to 70 percent of GDP upon full delivery of expected HIPC relief.

Subsequently, the economy has been adversely affected by the increase in international oil prices, which has slowed growth and contributed to higher inflation. Real GDP growth is expected to have moderated to 4 percent $y / y$ in 2005 while inflation ended the year at 9.6 percent $y / y$ and the foreign currency reserve coverage ratio decreased to about 2.6 months of imports. The program went offtrack at the end of 2004 reflecting the impact of heightened political tensions on policy implementation. Since then the authorities have sought to reforge the domestic political consensus for economic reforms, strengthen the macro-policy framework and advance key structural reforms to bring the program back on track. They have taken measures to bolster fiscal performance such that the consolidated public sector (CPS) deficit after grants is expected to fall to 2.2 percent of GDP in 2005. Meanwhile, monetary policy has continued to be conducted in the context of the crawling peg exchange rate regime with the currency depreciating by 5 percent per annum.

In order to strengthen the macro-policy framework further, the 2006 budget targets an unchanged CPS deficit in 2006 at 2.2 percent of GDP which should support stability in the run-up to this year's elections. To preserve competitiveness and the room for poverty spending, the budget contains the growth of the public sector wage bill broadly in line with expected inflation. Since adoption of Nicaragua's first PRSP in 2001, poverty reducing spending has been increased from about 10 percent of GDP in 2002 to 131/2 percent of GDP projected for 2005.

The authorities have made renewed advances on the structural reform agenda in recent months. The assembly has approved three key financial sector laws, which together represent significant reforms in line with FSAP recommendations. They have also approved the financial administration law which strengthens budgetary procedures and the fiscal framework. Other measures have sought to off set the fiscal impact of the decentralization process and contain losses in the electricity sector.

\section{Executive Board Assessment}

Executive Directors commended the Nicaraguan authorities for maintaining a broadly stable macroeconomic framework, with continued growth, rising reserves, and lower fiscal deficits. They welcomed the efforts of the authorities to strengthen the domestic consensus in favor of the reform agenda supported by the PRGF arrangement. The recent political accord has allowed for passage of key measures under Nicaragua's reform program that hold the promise of strengthening medium-term sustainability, and supporting the economic growth that will be needed to reduce poverty levels-which remain among the highest in the region-and to achieve the Millennium Development Goals (MDGs). In this context, Directors welcomed the authorities' commitment to use resources set free through the debt reduction provided by the Fund to Nicaragua under the Multilateral Debt Relief Initiative (MDRI) for poverty-reducing spending, and 
recommended that such spending be monitored closely. They encouraged the authorities to continue negotiations with creditors, including non-Paris Club creditors.

Directors cautioned that, despite the positive orientation of recent policies, significant vulnerabilities remain, including from the level of public debt—which is still high even after MDRI debt reductiona large current account deficit, and widespread financial system dollarization. In that light, prudent macroeconomic policy implementation will be important, focusing on key structural reforms in the fiscal, energy, and financial sectors aimed at fostering growth and promoting fiscal consolidationwhile increasing the scope for poverty-reducing spending. Directors welcomed Nicaragua's approval of the U.S.-Central America-Dominican Republic Free Trade Agreement (CAFTA-DR), but noted the need to improve the investment climate, governance, and the legal and regulatory framework further in order to leverage fully the Agreement's potential.

Directors welcomed the authorities' progress in implementing the poverty reduction strategy, and the revised and improved second-generation PRSP (PRSP-II) that has been incorporated in the 2005-2009 National Development Plan. They broadly welcomed the formulation of the PRSP-II through a participatory process, and its emphasis on increasing economic activity and employment in order to promote poverty reduction. Directors noted that poverty-reducing spending has increased, resulting in an improvement in indicators in the education and water sectors. They looked forward to the release of more recent data regarding poverty trends.

Directors commended the authorities for the disciplined fiscal policy stance of the 2006 budget, which will support stability in the run-up to the elections. They stressed the importance of adhering to the budget framework in the election year, and of identifying measures that could be taken in the event of unforeseen shocks.

Directors encouraged the authorities, in light of the rapid growth of public sector wages over the last few years, to maintain tight control over the public sector wage bill. They therefore welcomed that the budget broadly contains the growth of the wage bill in 2006 to the expected inflation rate. They urged the authorities to resist any pressures to increase public sector wages beyond program levels. At the same time, a few Directors recommended that the authorities re-examine the structure of the public sector wage bill to ensure that priority pro-poor services were not compromised.

Directors supported the steps taken by the authorities to contain losses in the electricity sector, which had begun to threaten the overall fiscal position, while protecting low-income electricity consumers through targeted subsidies. Looking ahead, Directors noted that further rate increases would likely be needed to fully eliminate losses. They emphasized the need to strengthen the regulatory framework to attract much-needed investment in energy assets. In this regard, the recently approved Energy Stability Law should be amended to eliminate distortional interventions in the energy market.

Directors welcomed the central bank's intention to tighten liquidity conditions to curb rapid credit growth and safeguard reserves. They noted that this would also help contain the recent pick-up of inflation, which seemed to reflect in part second-round effects of the oil shock and demand pressures from rapid growth in credit and public wages. Directors agreed that the current crawling peg exchange rate system is appropriate, and that keeping the rate of crawl of the depreciation of 
the córdoba unchanged in 2006 would appropriately balance stability and competitiveness. At the same time, Directors recommended that, after financial sector strengthening and full credibility of the macroeconomic policy framework have been secured, the authorities should consider moving over the medium term toward a more flexible exchange rate arrangement.

Directors stressed the importance of taking early steps to strengthen the elements of the tax code governing the powers and operations of the tax administration. In this regard, they were concerned that the tax code approved last year would weaken the authority of the tax administration and could undermine revenue collection. Accordingly, Directors urged the authorities to amend the law soon in line with international best practice, as envisaged under the program.

Directors welcomed the measures taken to safeguard the fiscal framework, including the passage of the Financial Administration Law. They stressed that a significant fiscal reform agenda remains to be articulated and implemented. In particular, Directors highlighted the need to develop a plan to set the public pension system on a sound actuarial foundation and prepare a strategy to introduce a disciplined fiscal responsibility framework. The decentralization framework needs to be reformed to link the devolution of revenue transfers to municipalities with spending responsibilities and accountability in a transparent manner. Directors also advised the authorities to consider reducing earmarking of budgetary resources over time to support fiscal flexibility. They looked forward to action in these critical areas soon after the elections.

Directors commended the authorities for the approval of several key laws on banking and supervision, in line with many core FSAP recommendations, which they considered have strengthened the financial sector framework. However, further work is needed to ensure smooth implementation of these laws. Directors welcomed the authorities' plans to incorporate additional FSAP recommendations into their reform agenda, in particular, to strengthen central bank independence and reinforce the protection of bank supervisors, especially against criminal prosecution related to their good-faith official actions. The progress made in strengthening the legal and institutional framework to counter money laundering and the financing of terrorism was noted, but the authorities were encouraged to expand the Financial Analysis Commission and create an independent Financial Intelligence Unit.

Public Information Notices (PINs) form part of the IMF's efforts to promote transparency of the IMF's views and analysis of economic developments and policies. With the consent of the country (or countries) concerned, PINs are issued after Executive Board discussions of Article IV consultations with member countries, of its surveillance of developments at the regional level, of post-program monitoring, and of ex post assessments of member countries with longer-term program engagements. PINs are also issued after Executive Board discussions of general policy matters, unless otherwise decided by the Executive Board in a particular case. The Staff Report for the 2005 Article IV Consultation with Nicaragua is also available. 
Nicaragua: Selected Economic Indicators

$2002 \quad 2003 \quad 2004 \quad 2005$

Domestic economy

GDP growth (percent)

CPI (eop, in percent) $1 /$

$\begin{array}{llll}0.8 & 2.3 & 5.1 & 4.0 \\ 4.0 & 6.6 & 9.3 & 9.6\end{array}$

\section{External sector}

Current account

(in percent of GDP)

Exports of goods, f.o.b

Imports of goods, f.o.b.

Gross international reserves 1/

\section{Combined public sector}

Primary balance

In millions of US\$

Overall balance before grants

Grants

Overall balance after grants

Combined public sector debt

Domestic debt

External debt 2/

$\begin{array}{rrrr}-767 & -749 & -732 & -845 \\ -19.1 & -18.1 & -16.1 & -16.9 \\ 917 & 1,050 & 1,363 & 1,543 \\ -1,834 & -2,021 & -2,452 & -2,911 \\ 454 & 504 & 670 & 730\end{array}$

In percent of GDP

$\begin{array}{rrrr}-3.3 & -3.3 & -3.2 & -3.6 \\ -8.3 & -7.6 & -6.3 & -6.0 \\ 2.9 & 3.4 & 3.6 & 3.8 \\ -5.4 & -4.2 & -2.8 & -2.2 \\ & & & \\ 197.7 & 213.5 & 92.7 & 87.6 \\ 21.3 & 34.4 & 29.4 & 26.3 \\ 176.5 & 179.1 & 63.3 & 61.3\end{array}$

\section{Memorandum items:}

Nominal GDP (C\$ mn)

GDP (US\$ mn)

Gross reserves $1 /$

(in months of imports of G\&NFS)

NIR Adjusted (US\$ mn) 1/

$\begin{array}{rrrr}57,376 & 62,674 & 72,603 & 83,793 \\ 4,025 & 4,147 & 4,556 & 5,008 \\ & & & \\ 2.8 & 2.1 & 2.8 & 2.6 \\ 64 & 83 & 211 & 282\end{array}$

Sources: Central Bank of Nicaragua; Ministry of Finance; and IMF staff estimates/projections.

1/ Actual outcome.

2/ After HIPC relief, assuming that negotiations with non-Paris Club and commercial creditors are completed by end-2005. Includes accrued interests on private debt in arrears. 
Press Release No. 06/13

FOR IMMEDIATE RELEASE

January 18, 2006
International Monetary Fund

Washington, D.C. 20431 USA

\section{IMF Executive Board Approves Seventh, Eighth and Ninth Reviews Under Nicaragua's PRGF Arrangement}

The Executive Board of the International Monetary Fund (IMF) completed today the seventh, eighth and ninth reviews of Nicaragua's performance under its Poverty Reduction and Growth Facility (PRGF) arrangement. In completing the reviews, the Executive Board approved Nicaragua's requests for a waiver of performance criteria and an extension of the arrangement from February 28, 2006 to December 12, 2006. In addition, the Executive Board completed the financing assurances review under Nicaragua's PRGF arrangement.

The completion of the reviews makes available SDR 13.9 million (about US\$20.1 million) for disbursement. Nicaragua's three-year PRGF arrangement amounting to SDR 97.5 million (about US\$140.9 million) was approved in December 2002 (see Press Release No. 02/53). Completion of the latest reviews will bring total disbursements under the arrangement to SDR 69.7 million (about US\$100.7 million).

After the Executive Board's discussion of Nicaragua, Mr. Agustín Carstens, Deputy Managing Director and Acting Chair, issued the following statement:

'Nicaragua's performance under the PRGF arrangement has strengthened, as the domestic consensus for economic reforms has been rebuilt despite a difficult political environment.

Key policy measures under the PRGF-supported reform program have been approved, including fiscal and financial sector reforms. Nicaragua's recent approval of the US-Central AmericaDominican Republic Free Trade Agreement (CAFTA-DR) is also very welcome.

"Economic developments were broadly positive in 2005, notwithstanding pressure from higher oil prices. Output continues to grow at a moderate pace, reserves have increased, and the fiscal deficit has been contained, although the high level of inflation remains a concern. The IMF has granted Nicaragua debt reduction under the Multilateral Debt Relief Initiative (MDRI), and the authorities are committed to using the resources thus freed for poverty-reducing spending. At the same time, it is important to strengthen debt reduction efforts by continuing negotiations with Nicaragua's creditors, including non-Paris Club creditors. 
"Nicaragua nevertheless continues to face important economic vulnerabilities, in particular from a still-high public debt, a large external current account deficit, and widespread financial dollarization.

“The authorities' medium-term strategy focuses on boosting growth through private sector development while maintaining macroeconomic stability, to help further reduce poverty while moving toward achieving the Millennium Development Goals. Going forward, the fiscal consolidation process will need to continue, as will efforts to strengthen the investment climate so as to take full advantage of the opportunities afforded by CAFTA-DR.

"The fiscal strategy for 2006 is centered on containing the budget deficit, while preserving the room for poverty reducing spending. The authorities are committed to keeping growth of the public sector wage bill in line with expected inflation to maintain stability, protect competitiveness and avoid crowding out poverty spending. Steps have also been taken to eliminate losses in the electricity sector, and the authorities intend to review the legal framework for the sector to eliminate distortional interventions that could deter needed investment.

"Nicaragua's key challenge going forward will be to strengthen the fiscal framework to assure sustainability, and preserve the space for needed investment and poverty-reducing spending. In this vein, tax administration will need to be strengthened, including by revising the tax code. It will also be important to move ahead with reforms of the decentralization framework to ensure that the transfer of revenues to municipalities is matched by the devolution of spending responsibilities. Focus will also need to be placed on returning the public pension system to actuarial soundness, and developing a credible fiscal responsibility framework.

"The authorities have moved forward with reforms to strengthen the financial sector, including the passage of important financial sector legislation. They plan to prepare a roadmap to implement additional reforms recommended in the context of the Financial Sector Assessment Program (FSAP).

"The authorities are to be commended for their strong commitment to the reform agenda, which has helped to maintain a stable macroeconomic framework and set the stage for the implementation of structural reforms that will be key to growth and poverty reduction. The authorities' focus on good governance and the fight against corruption is also essential to achieving strong and lasting growth and poverty alleviation. At the same time, Nicaragua will continue to depend on international support to reinforce its reform efforts," Mr. Carstens said. 


\section{Statement by Moises Schwartz, Executive Director for Nicaragua and Nina Conrado, Senior Advisor to Executive Director January 18, 2006}

On behalf of the Government of Nicaragua we would like to thank staff and management for their policy advice and for their disposition for a continuous open dialogue. We would also like to thank Executive Directors for their support to the country, especially with the recent approval of the Multilateral Debt Relief Initiative. The authorities of Nicaragua are committed to continue using freed up resources from debt relief to fight poverty and help achieving the MDGs.

Our Nicaraguan authorities have shown a strong commitment and ownership of their economic program, which has been supported by a PRGF arrangement. In late 2004, in the framework of positive macroeconomic results and over performance of quantitative targets, the program went off-track, with the approval of the 2005 budget that increased the deficit in relation with the executives proposal. At the same time, the approval of constitutional reforms without domestic consensus resulted in a tense political environment that affected the structural reform agenda. During the first half of the year the government moved quickly to protect the core elements of the program, identifying tax measures and implementing a more strict control of expenditures. The fiscal targets went back on track and technical discussions on structural reforms advanced despite the difficult political environment.

With the main objective of protecting macroeconomic stability, a wide political consensus was achieved in the last months of 2005, which postponed approved constitutional reforms until after the next presidential elections. With this new accord, the National Dialogue was an effective scenario to agree on key policies, including ten prior actions to bring the PRGF back on track. Taking into consideration the political scenario of the 2006 electoral year, there was a front loading of economic and structural measures, which included the approval on the 2006 budget, strengthening of financial laws, the approval of a financial administration law, increases in electricity tariffs and reforms in the area of decentralization.

Despite uncertainties related to the political environment and the negative impact of the oil shock, the macroeconomic framework for 2005 was positive. High oil prices not only had a direct impact on inflation and on the current account, but also resulted in pressures for subsidies in the transport and electricity sectors, as well as greater demands for public wage increases. Nevertheless, the inflation rate was maintained in a single digit ( 9.6 percent $\mathrm{y} / \mathrm{y}$ at end 2005), the monthly indicator of economic activity for October shows a 4.9 percent growth rate, in line with the projected GDP growth of 4 percent, and employment has been growing. At the same time, export growth and the increase in remittances helped reduce the impact of the oil bill on the current account, and the disbursement of external resources and reduction of debt service made it possible to accumulate international reserves.

Based on a satisfactory macroeconomic performance and the compliance of prior actions Nicaraguan authorities request the completion of the seventh, eight and ninth reviews under 
the PRGF and waivers for the nonobservance of two performance criteria. The first one for a small breach on the target for the overall balance after grants of the central government at end 2004, and the second one on the structural PC of submitting to the National Assembly a fiscal responsibility law. They also request an extension of the arrangement to December 2006 to continue supporting sound macroeconomic policies, especially during this electoral year.

\section{Fiscal policy}

The fiscal strategy for 2005 and for the 2006 budget has included the strengthening of revenues and prioritization and improvement on control over expenditures. This, coupled with debt service relief, has permitted an increase in poverty reducing expenditures.

Revenues have been growing at a strong rate reflecting tax measures, growth in economic activity and administrative efforts. Tax reforms during this administration have resulted in an improvement on the composition of the tax structure, increasing revenues from income taxes. To further strengthen tax collection and as part of the structural agenda, a Tax Code was approved in 2005. The authorities are aware that the tax code contains weaknesses and have already initiated technical discussions with the National Assembly to achieve the consensus to make reforms. A PC on these reforms has been established for March 2006.

In terms of expenditures, two major policy issues refer to decentralization and the wage bill. As part of the prior actions to complete this review, the 2006 budget approved maintains the transfer to municipalities to 6 percent of revenues and includes a devolution of expenditures equal to half of the transfer. The transfer law was amended to delay the increase in transfers in the medium term, and a presidential decree was passed to curtail central government spending in areas that should be the responsibility of municipalities. In order to further improve the decentralization framework, an agreement was reached with political parties to reform the municipal transfer and municipality law. A structural benchmark regarding these reforms has been established in the program.

In relation to wage policy, the authorities are aware of the possible risks associated with rapid wage increases and have agreed to monitor the wage bill as a PC on the program. Despite the legal restrictions and limitations regarding wage policy, the authorities have taken corrective measures to limit the growth of the wage bill, including eliminating vacancies and lowering wage payments to consultants. However, it is important to mention that wage increases have been in line with civil service reform and have been targeted to priority sectors such as health and education.

Quasifiscal losses related to the electricity sector have also been addressed. Adjustment of electricity tariffs to eliminate the fiscal impact of losses of the power sector started in July, accumulating a 20 percent adjustment through January 2006, while maintaining targeted subsidies to low usage consumers. In September an Energy Stability Law (ESL) was approved allowing for high frequency adjustments. A PC to monitor further price adjustments is being introduced, and a PC has been established to strengthen the ESL to eliminate potential distortions to the sector. 
In order to strengthen the fiscal framework, a Financial Administration Law was approved in 2005 and the development of a road map for the approval of a fiscal responsibility law was established as a PC. The road map will address important vulnerabilities such as the earmarking of spending, to be considered by the next administration. Additionally, reforms to the pension system were postponed, and the preparation of strategy for implementation of a new reform has been established as a PC.

\section{Monetary and financial policy}

The monetary program for 2005 was based on an effective coordination with fiscal policy, that supported the strengthening of international reserves and the continuation of the policy of domestic debt reduction. During the first half of the year, after over performing in 2004, there was a moderate loss of international reserves, as a result of delays in disbursement of external resources and lower open market operations related to uncertainties of the political environment. Nevertheless, during the last months of 2005 monetary policy was tightened, which coupled with a strong demand for monetary base, a stronger fiscal position than expected, and external disbursement, resulted in the accumulation of reserves above the annual target.

The authorities believe that their prudent monetary policy has been consistent with the objective of supporting the exchange rate system, which has served appropriately as the main instrument to anchor inflation expectations. At the same time, monetary policy has reduced the central banks financial vulnerability by reducing the stock and financial cost of domestic debt. For the medium term, the authorities are aware of the convenience of continuing to reassess the exchange rate system, taking also into consideration relevant conditions such as development of domestic capital market and sound fiscal policies among others. For 2006, the monetary program will maintain the 5 percent crawling peg of the exchange rate and will aim at further strengthening central bank reserve position, especially during the first semester.

Substantial progress has been made in strengthening the legal financial framework, in line with FSAP recommendations. In 2005, reforms were made to the banking law, the law of superintendency of banks and the deposit insurance fund. The government plans to develop a road map to further improve the financial sector framework.

\section{Debt sustainability}

Debt sustainability has been at the core of this governments economic policy. Debt strategy has included many fronts, the most important being the access to international initiatives such as the HIPC initiative and more recently the MDRI. Other important policies have included the strengthening of the debt framework through the implementation of the debt law, the improvement of the debt monitoring system and the renegotiation of domestic debt. These measures, coupled with fiscal consolidation have resulted in a positive impact on long term sustainability, however, more still needs to be done. 
Important steps have been taken regarding debt reduction. Thanks to the HIPC initiative, Nicaragua has successfully completed negotiations with all its Paris Club creditors, basically all its multilateral creditors, and nine non-Paris club creditors, covering together 61 percent of expected HIPC debt relief. It is important to mention that in all its negotiations with external creditors Nicaragua has adhered to the principles of comparable treatment and equitable burden sharing.

The authorities are committed to continue implementing sound macroeconomic policies, focusing on fiscal adjustment and a responsible debt policy. The government is committed with the rest of the international community to advance towards debt sustainability and liberate resources to help achieve the MDGs.

\section{Looking forward}

As part of the poverty reduction strategy, a second generation PRSP-II has been revised and improved, and is now incorporated in the 2005-2009 National Development Plan. The strategy focuses in four key areas: (i) economic growth for poverty reduction (ii) human capital development and social protection, (iii) productive and social public infrastructure and (iv) governance and state reforms.

The authorities believe that a comprehensive national plan is being presented. Private sector led growth is being fostered with an improved investment climate based on macroeconomic stability, improvement in public infrastructure and initiatives such as HIPC, MDRI and CAFTA-DR. Public spending is being rationalized, supported by efforts to achieve a multiyear budgeting process, and prioritization of poverty reducing expenditures, including the tracking of HIPC debt relief through the Supplementary Social Fund. International cooperation is being harmonized, the Joint Financial Agreement for General Budget Support signed on May 2005 is another proof of the international communitys support and confidence on the transparency and ownership of the governments economic program, and in 2006 the first investments of the US funded Millennium Challenge Account are expected to take place.

The Nicaraguan government believes that the completion of the pending reviews of the PRGF as well as the extension of the program will serve as basis for the continuation of sound macroeconomic policies during the last year of this administration and during this years electoral period, and will provide an ap propriate framework for Nicaraguas long term objective of growth and poverty reduction. In line with the governments transparency policy the authorities intent to publish the related documents of this review. 